\title{
Aproximación urbana y bioarqueológica de la Repoblación medieval del Campo de Montiel: Peñaflor
}

\author{
Settlement and bioarchaeological approach of medieval \\ Repopulation in Campo de Montiel: Peñaflor
}

\author{
Pedro R. Moya-Maleno \\ Proyecto Arqueológico "Entorno Jamila" \\ entornojamila@gmail.com \\ Alfonso Monsalve Romera \\ Universidad de Granada \\ alfmonro@correo.ugr.es
}

Recibido: $17 / 11 / 2014$

Aceptado: 03/03/2015

\section{RESUMEN}

Este artículo presenta los resultados arqueológicos y antropológicos de las últimas campañas en la aldea fortificada de Peñaflor, un pequeño asentamiento en altura asociado a los movimientos de conquista y repoblación cristiana en los últimos territorios musulmanes en La Meseta, a priori, desde la primera década del siglo XIII. El análisis del territorio, del urbanismo y de la necrópolis intervenida en 2004 y 2013 nos permite, como novedad, avanzar en la zona sobre las características y evolución de enclaves cristianos defendidos con cerca, así como obtener una primera panorámica bioarqueológica de sus habitantes.

Palabras clave: Peñaflor, Bioarqueología, Paleopatología, Reconquista, Campo de Montiel, Orden de Santiago, Alcaraz.

\begin{abstract}
This paper shows the results of archaeological and anthropological recent researches in the hillfort of Peñaflor, a small settlement associated with the Reconquista and Christian repopulation of the last Muslim territories in the Iberian Plateau. A priori, from the first decade of XIII century. Our analysis of the territorial and urban patterns, and the excavation in the necropolis (2004 and 2013), allows us, innovatively, progress in the area about the characteristics and evolution of Christian closed settlements; and finally, get a first bioarchaeological overview of their inhabitants.
\end{abstract}

Key words: Peñaflor, Bioarchaeology, Paleopathology, Reconquista, Campo de Montiel, Orden de Santiago, Alcaraz.

Sumario: 1. Introducción. 2. El asentamiento de Peñaflor. 2.1. Territorio circundante. 2.2.Topografía del cerro y accesos. 2.3. Intramuros. 2.4 Defensas. 2.5. Necrópolis. 3. Estudio antropológico. 3.1. Material. 3.2. Método. 3.3. Resultados. 4. Conclusiones. 


\section{INTRODUCCIÓN}

Después de casi dos décadas sin intervenir ni investigar en el cerro Castillón o Castellón de Villanueva de los Infantes (Ciudad Real), a principios del siglo XXI tuvo lugar el inicio de una nueva etapa en su estudio. Esta fase, en la que todavía nos encontramos, se activó a raíz del peligro de ruina de las estructuras exhumadas en los años 80 del siglo pasado y, especialmente, ante la manifiesta destrucción de lo que, ya desde un primer momento, entendimos como una necrópolis en la falda Sur del cerro.

La intervención inicial de 1984 en el cerro Castillón, a menos de $2 \mathrm{~km}$ al Suroeste de la mencionada capital del Campo de Montiel (Fig. 1), constituyó la primera excavación moderna en la zona y culminaba una serie de prospecciones y estudios territoriales de la Prehistoria Reciente llevados a cabo por Juan José Espadas Pavón ${ }^{1}$. La importancia arqueológica de este emplazamiento se hizo evidente con el estudio de los primeros restos materiales ${ }^{2}$ y aún más patente en las dos excavaciones consiguientes, 1985 y 1986. Las tres campañas en la superficie y en la ladera Noroeste del cerro permitieron ubicar en este lugar un potente asentamiento de época calcolítica a tenor de los testimonios cerámicos, líticos y óseos, entre otros ${ }^{3}$. Una relevancia en el panorama prehistórico de La Meseta que todavía se mantiene ${ }^{4}$.

Desgraciadamente, el mayor interés por las cronologías prehistóricas de los investigadores dejó de lado el estudio de otras etapas históricas también presentes en el cerro Castillón. A pesar de reconocer y distinguir el poblamiento medieval del lugar, no se publico nada al respecto del mismo más allá de planimetrías del muro Norte y de estratigrafías en las que -suponemos- también se encuentren paquetes sedimentarios del medioevo 5 .

Aparte de la sucinta mención de M. Corchado ${ }^{6}$ al lugar, la verdadera valoración de la ocupación medieval del Castillón vino de la mano de Amador Ruibal, quien en 1987 publicó brevemente una recopilación de fuentes y algunas conclusiones resultado de su visita ${ }^{7}$. Este opúsculo formaba parte de un plan de revisión de las fortificaciones conocidas del Campo de Montiel $^{8}$ e identificó sobre el terreno la existencia en

1 Espadas Pavón, "Prospecciones en el Campo de Montiel II...".

2 Espadas ET AL., "El poblado calcolítico 'El Castellón'...".

${ }^{3}$ IBID.; EsPADAS ET AL., "Memoria preliminar de las excavaciones..."; Poyato y EsPadas, "El Castellón, un importante yacimiento con campaniforme..."; Poyato y GaLÁn, "Las cerámicas del 'grupo Dornajos' de la Mancha Oriental".

${ }^{4}$ Garrido, “El campaniforme en la Meseta Sur...”, pp. 128, 130 y 142; Moya-Maleno, “Caminante, no hay camino...? Territorio y economía de la Edad del Bronce...".

5 EsPadAs ET AL., "Memoria preliminar de las excavaciones...", pp. 67 y 69. La forma y fondo de enfocar sendas publicaciones son acordes a su momento en España y en la zona tal y como ya analizamos: MoyAMaleno, "García y Bellido y la Arqueología del Campo de Montiel...". Mientras que se estaba gestando una nueva disciplina arqueológica en el ámbito prehistórico - y en menor medida romano-, el interés medievalista ponía el foco todavía más en los textos que en los contextos arqueológicos. El caso de A. Ruibal puede considerarse la excepción que confirma la regla (vid. infra).

${ }^{6}$ Corchado, Avance de un estudio geográfico-histórico..., p. 136.

7 Ruibal, "Peñaflor y Saujuolo, dos despoblados cristianos del siglo XIII".

${ }^{8}$ Ruibal, "Eznavexore o ¿Torres de Xoray?: vestigios..."; ÍD “El enclave de Montiel: vestigios..."; ÍD "El Castillo de Alhambra"; Íd "Un enclave de la Orden de Santiago en el...". 
este lugar de la aldea de Peñaflor que mencionan distintos documentos medievales y de la Edad Moderna9.

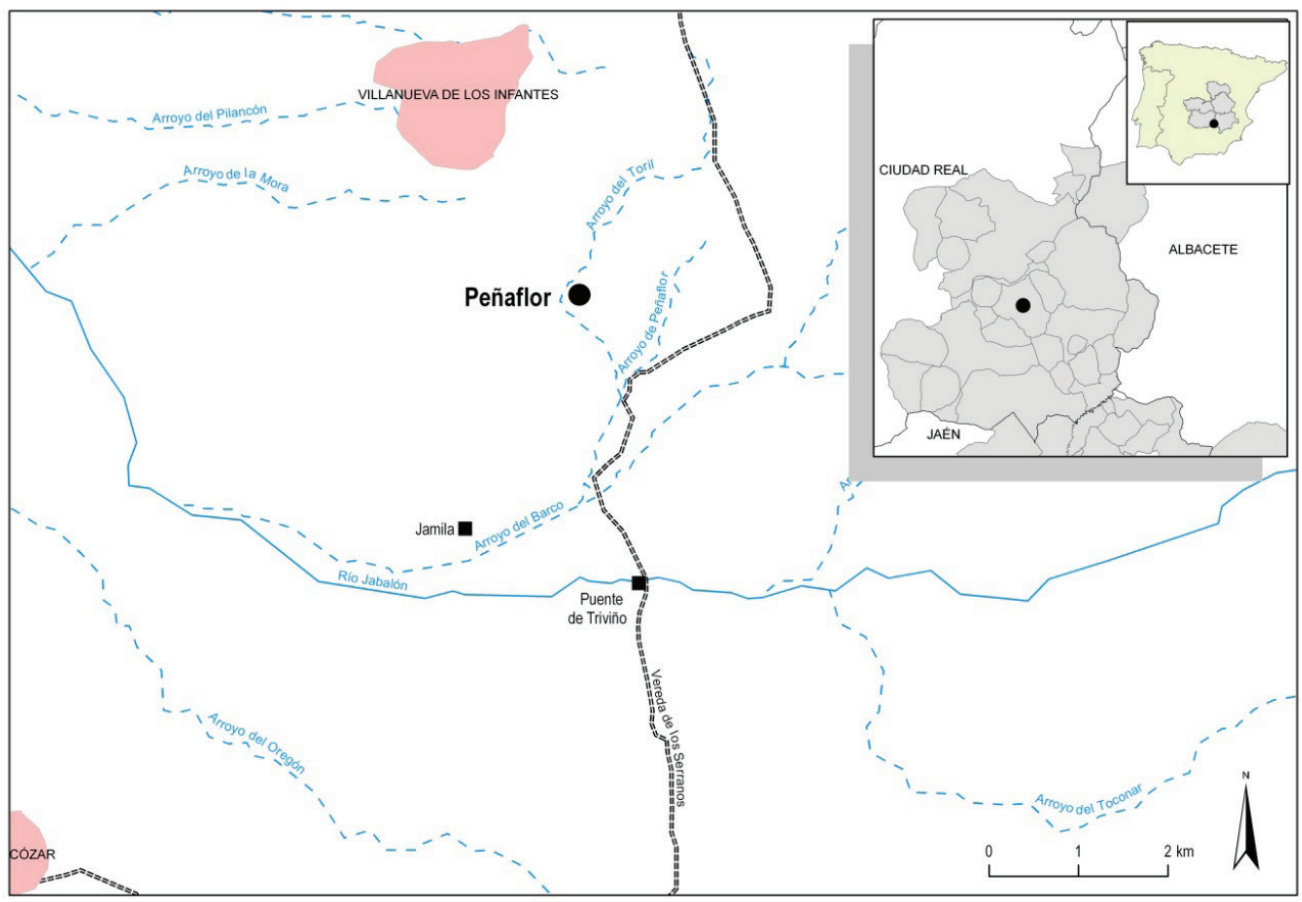

Fig. 1. Localización del cerro Castillón, en el que se ubicó el lugar de Peñaflor.

Dado que distintos autores hemos expuesto y centrado las fuentes históricas al respecto de Peñaflor ${ }^{10}$, y otros autores se han adentrado en la ocupación y litigios territoriales cristianos del siglo XIII en los que Peñaflor se halló inmersa ${ }^{11}$, no es nuestra misión redundar en ello. Grosso modo, cabe señalar cómo la primera mención conocida al núcleo de Pennaflor aparece en 1215, cuando la Orden de Santiago cedió la mitad de su pobla al poderoso Álvaro Núñez de Lara. Después, en 1232, cuando el Maestre don Pedro González Mengo cede temporalmente -para los días de su vida- a don García Pérez, alcalde del rey, la mitad de Peñaflor, pobla que se halla en el térmi-

9 Inter alia, Chaves, Apuntamiento Legal sobre el dominio solar..., pp. 17, 41 y 191; GonZÁLEz GonZÁLEZ, Repoblación en Castilla La Nueva, p. 357; ÍD “La Repoblación de La Mancha”. Corchado, Iniciación al estudio geográfico-histórico del priorato de Uclés...; Vid. infra.

10 Ruibal, "Peñaflor y Saujuolo, dos despoblados cristianos del siglo XIII"; EsPadas y Moya-MaLENO, "Cuando la tierra se abre. Intervención de urgencia en una necrópolis de 'El Castillón'...”.

11 GonzÁlez GonzÁlez, Repoblación en Castilla La Nueva; Íd "La Repoblación de La Mancha”; MATELlanes, "La colonización Santiaguista del Campo de Montiel”, pp. 115-143; Íd "La Orden de Santiago y la organización social de la Transierra..."; PRETEL, "Conflictos de interés en el repartimiento y la repoblación..."; ÍD Alcaraz y su tierra en el siglo XIII; MADRID, "Los orígenes de la presencia de la Orden de Santiago...". Ayala, "Las Órdenes Militares y la ocupación del territorio manchego...”; ÍD., Las órdenes militares hispánicas en la Edad Media. 
no de Montiel $^{12}$. Unos años después, en 1243, figurará entre lo reclamado unos años antes por el arzobispo de Toledo -Ximénez de Rada-contra la orden de Santiago por supuestamente haber fundado estas iglesias sin su consentimiento ${ }^{13}$. Posteriormente la sentencia arbitral de Fernando III en el pleito entre Alcaraz y la Orden de Santiago sobre las poblaciones del Campo de Montiel vuelven a mencionarla pero como despoblado $^{14}$ (Fig. 2).

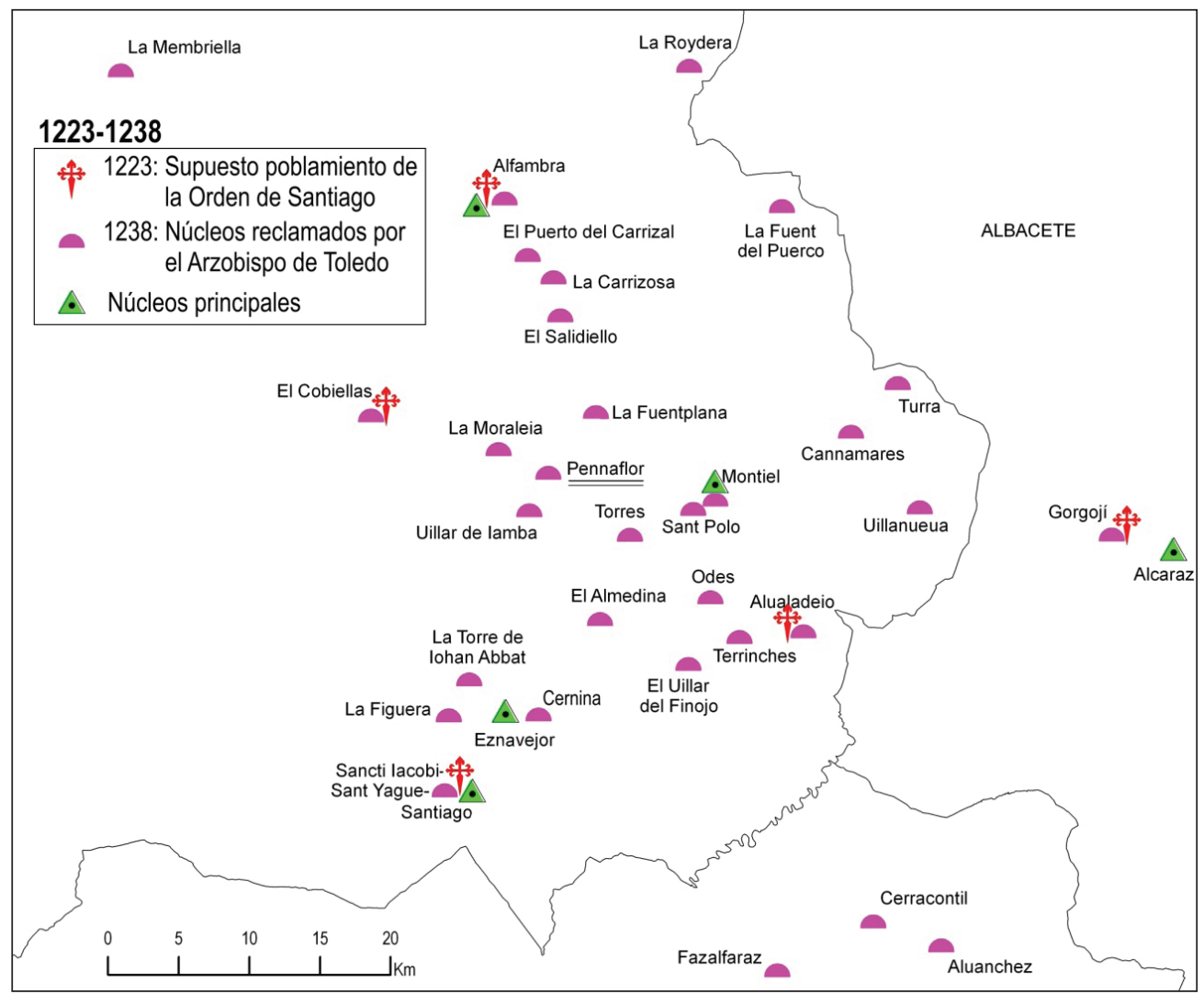

Fig. 2. Ocupación santiaguista del Campo de Montiel según la historiografía y los litigios entre la Orden de Santiago y el Arzobispado de Toledo en el siglo XIII. Faltan por ubicar en esta zona Uilla Alua, La Fuent de la Sarza y Açuuer, de localización incierta.

12 González GonzÁlez, Repoblación en Castilla La Nueva, p. 357; Madrid, "Los orígenes de la presencia de la Orden de Santiago...”.

13 1238, Junio, 20, Letran. Pub. Lomax, “El arzobispo don Rodrigo Jiménez de Rada...”, § 1, pp. 348-360.

Í⿴囗́ p. 112 .

${ }^{14}$ Chaves, Apuntamiento Legal sobre el dominio solar..., p. 17; Pub. Bullarium equestris ordinis..., fols. 160-162; GonzÁlez GonzÁlez, Reinado y diplomas de Fernando III, pp. 254-257 §705; Pretel, Alcaraz y su tierra en el siglo XIII, p. $245 \S 11$ con refs. 
Peñaflor seguirá apareciendo en la diplomática y visitas de la orden, pues quedará ligada a la encomienda de Carrizosa y Peñaflor ${ }^{15} \mathrm{y}$, finalmente, como dehesa de Villanueva de los Infantes ${ }^{16}$. Sin embargo, pese a su aparente temprano abandono, llama la atención cómo todavía entre finales del siglo XV y principios del siglo XVI distintas fuentes señalan un lugar defensivo operativo aquí. En la visita de 1480 la villa de La Moralexa dice tener una fortaleza que llaman de Peñaflor, que esta la parte del Sur de ella ${ }^{17}$; igualmente, la Cosmografía de Hernando Colón localizaba el "castillo de peñaflor" a un cuarto de legua de Infantes ${ }^{18}$. Éstas permiten dilatar varios siglos, cuanto menos, la importancia estratégica del emplazamiento fortificado de Peñaflor y quizás, incluso, algún tipo de población asociado a él. Este hecho reforzaría la ya habitual denominación como castellones a asentamientos Calcolíticos y de la Edad de Bronce ${ }^{19}$ y la perduración del topónimo El Castillón.

Si el final de la ocupación de Peñaflor es todavía incierto, también lo es su comienzo. Como bien es conocido, victoriosos de Las Navas de Tolosa ${ }^{20}$, en 1213 acaeció la gran operación de conquista cristiana en la zona de mano de las cabalgadas de Alfonso VIII sobre las plazas de Alhambra, Eznavexore (Villamanrique) y Alcaraz, lo cual ha sido interpretada con frecuencia como el inicio de la presencia cristiana en estas tierras ${ }^{21}$. Las primeras fechas que estamos obteniendo en la necrópolis de Peñaflor coinciden en centrar la datación del asentamiento en los dos cuartos centrales del siglo XIII. No obstante, aunque con menor grado de certeza, los resultados de radiocarbono obtenidos también podrían remontar la presencia cristiana en Peñaflor cuando menos desde el último cuarto del siglo XII. Este hecho estaría en consonancia con los textos que señalan repartos y donaciones unos años antes de la bula alejandrina de $1175^{22}$.

En 2004 y 2013 tuvieron lugar sendas excavaciones en el cerro Castillón en lo que ya desde un principio se intuía como el cementerio de la aldea de Peñaflor ${ }^{23}$. En

15 Corchado, Avance de un estudio geográfico-histórico..., p. 136. MadRID, "Jorge Manrique, comendador de Montizón”, p. 330; Molina, "Iglesias parroquiales del Campo de Montiel...”, p. 24; EscudERO, La Iglesia de Santa Catalina de La Solana, p. 234.

${ }^{16}$ CAmpos, "La descripción del Partido, Suelo y Campo de Montiel...", p. 176, fig. 1.

17 AHN, OO.MM., Santiago, ms. 1064, visita de 1480. Moya-Maleno, “ Procesos de reconquista, repoblación y abandono medievales...".

18 Colón, Descripción y Cosmografía de España, p. $126 \S 4504$ s.

19 Moya-Maleno, “¿Caminante, no hay camino...? Territorio y economía de la Edad del Bronce...”,passim.

${ }^{20}$ Cressier y Salvatierra, Las Navas de Tolosa, 1212-2013; Estepa y Carmona, La Península Ibérica en tiempos de Las Navas de Tolosa.

21 GonzÁlez González, Alfonso VIII, p. 605-607 § 919; Corchado, Avance de un estudio geográficohistórico..., pp. 42, 78, 136 y 179. Pretel, Alcaraz y su tierra en el siglo XIII; MADRID, "Los orígenes de la presencia de la Orden de Santiago...".

22 IBÍD.: es conocida la siempre problemática en discernir la veracidad de las fuentes escritas en materia de entrega de posesiones y donaciones a nobles y a la Orden de Santiago, puesto que no siempre es posible comprobar si era sobre territorios realmente conquistados o si, por el contrario, se trataba de un reparto previo del territorio a conquistar a modo de contrato para asegurar la participación de las huestes del beneficiado en la campaña. Para la Bula de Alejandro III: MARTín Rodríguez, Orígenes de la orden ..., pp. 248-254, § 73.

23 Espadas y Moya-Maleno, "Cuando la tierra se abre. Intervención de urgencia en una necrópolis de 'El Castillón'...", p. 385. 
ambos casos se ha tratado de intervenciones de urgencia puntuales en un subsuelo fuertemente alterado por la erosión y que hace precipitar ladera abajo los restos óseos inhumados ${ }^{24}$. Sobre un total de 29 individuos singularizados (vid. infra), el estudio radiocarbónico de tres de ellos procedentes de contextos cerrados originales-CEF1UF7 y UF4; CEF2-UF15-, como hemos señalado, les encuadra preferiblemente en el siglo XIII ${ }^{25}$. El ritual de inhumación seguido en las sepulturas (vid. infra), unido a otros indicios arqueológicos, son inequívocamente de adscripción cristiana.

Si bien los problemas de preservación hacen del rescate de este yacimiento una obligación para la investigación, las evidencias histórico-arqueológicas ahora documentadas también son contundentes para estudiar en extensión y detenidamente la necrópolis y hábitat de Peñaflor. Se trata de la primera oportunidad de analizar en el Campo de Montiel las características urbanas y sociales de una aldea de conquista o repoblación ex novo y sin apenas superposición poblacional en momentos posteriores; un asentamiento con un valor estratégico claro, como estamos empezando a comprender ${ }^{26}$, y que, antes que vincularlo a Alcaraz, podría estar reflejando el modus operandi de control del territorio y de hostigamiento en primera línea en un frente más o menos activo. En este caso, el contexto adverso lo encarnan los grandes castillos islámicos anteriormente mencionados y otros núcleos cercanos, como Alcubillas, Almedina y Cózar -a 12, 10 y $8 \mathrm{~km}$ respectivamente-, pero, sobre todo, el cerco a la fortaleza de Montiel -a $11 \mathrm{~km}-$, cuya plaza sí será la última gran posesión musulmana en caer definitivamente al Norte de Sierra Morena, en torno a 1227 y años después del paso de las Navas de Tolosa ${ }^{27}$.

Por desgracia, los trabajos arqueológicos para este proceso concreto, tanto para el ámbito musulmán como para el cristiano, son casi inexistentes. En unos casos, la superposición de los núcleos actuales, p.e. Almedina, impide tener contextos cerrados y bien definidos, al alimón con una atávica y enquistada insensibilidad patrimonial en la comarca ${ }^{28}$. Por otro lado, cuando sí se ha podido excavar, las cronologías detectadas

${ }^{24}$ Las dos excavaciones que el Proyecto Arqueológico 'Entorno Jamila' (PAEJ, www.entornojamila.es) tuvieron lugar en sendas quincenas de los veranos de 2004 y 2013. La de $2004-\mathrm{n}^{\circ} \exp 03.1758$ - fue codirigida por J.J. Espadas y Pedro R. Moya-Maleno, mientras que la de 2013 - $\mathrm{n}^{\circ}$ exp. 13.0382-, por Pedro R. MoyaMaleno y Daniel Hernández Palomino. Ambas han sido posibles, en primer lugar, gracias al apoyo económico y material de la Dirección General de Patrimonio de la Junta de Comunidades de Castilla-La Mancha y del M.I. Ayuntamiento de Villanueva de los Infantes al proyecto de investigación que encabeza el primero de los firmantes. Los estudios radiocarbónicos también han sido patrocinados dentro de la Orden de 01/04/2014, de la Consejería de Educación, Cultura y Deportes, por la que se establecen las bases y se convocan subvenciones para la realización de proyectos de investigación del patrimonio arqueológico y paleontológico de Castilla-La Mancha para el año 2014. [2014/4594]. No obstante, nótese que el equipo de trabajo, compuesto por arqueólogos y por antropólogos físicos especialistas han desempeñado sus investigaciones de forma altruista. Vid. (Moya-Maleno, "El 'Entorno Jamila' (Villanueva de los Infantes...”, pp. 367ss.

${ }^{25}$ Entre 1170 y 1285 . Las cronologías radiocarbónicas de Peñaflor se estudian con más detenimiento en Moya-Maleno, "Procesos de reconquista, repoblación y abandono medievales...".

${ }^{26}$ CAmpayo ET AL., "Territorio y comunicaciones medievales en el Alto Valle del Jabalón...".

${ }^{27}$ Corchado, Avance de un estudio geográfico-histórico..., pp. 49; Ruibal, "El enclave de Montiel: vestigios..."; Gallego y Lillo, "Estudio arqueológico del Castillo de la Estrella a través...”, p. 156.

${ }^{28}$ Moya-Maleno, "García y Bellido y la Arqueología del Campo de Montiel..."; Benítez de Lugo, "Protección y gestión de la Arqueología en Castilla-La Mancha..."; ÍD. ET AL., "Investigaciones arqueológicas en Mentesa Oretana...". 
no han dado con este momento de incipiente presencia cristiana, bien por los hados de la arqueología, bien por el propio interés de los arqueólogos que han trabajado en la zona, volcados en otras cronologías y en yacimientos sin esta presencia medieval.

Por excavación apenas nada conocemos del mundo musulmán en los casi 3.000 $\mathrm{km}^{2}$ de la comarca histórica del Campo de Montiel. Sólo algunas intervenciones en solares urbanos y periurbanos de Villanueva de la Fuente han aportado materiales y una necrópolis de la antigua Meintixa islámica, datada entre los siglos IX y XI ${ }^{29}$. En cuanto a la forma e intensidad del asentamiento cristiano - de Alcaraz o de la Orden de Santiago- en los momentos cruciales de finales del siglo XII y primera mitad del siglo XIII, dicha información procede casi íntegramente de los archivos. Y esto a pesar de que hay asentamientos ex novo y de corta ocupación sin superposición similares a Peñaflor en la comarca (Fig. 2). Por tanto, a expensas de que otros equipos arrojen luz sobre esta fase, sólo el Proyecto Arqueológico 'Entorno Jamila' (PAEJ) está avanzando al respecto de este tipo concreto de asentamientos con sendas intervenciones en el Castillón y en el propio yacimiento de Jamila ${ }^{30}$ (Fig. 1). El problema es que a día de hoy el edificio columnado de Jamila no se muestra como un núcleo poblado como tal, sino más bien como una ermita que centralizó, a modo de sinecismo, un poblamiento disperso en torno a ella en el valle del río Jabalón ${ }^{31}$.

Si éste es el panorama de una arqueología "clásica" centrada en las estructuras, es lógica la casi nula información existente en lo que a las características antropológicas de los habitantes medievales de la zona se refiere. Sólo conocemos el somero estudio de un par de individuos - de los 50 exhumados- de la mencionada maqbara mentesana $^{32}$; nada más para cronologías posteriores. Como ya pusieron de manifiesto los responsables de las intervenciones de Mentesa, se trata de una triste realidad de la investigación musulmana y medieval generalizada en toda la región ${ }^{33}$, cuestión ésta que nos conduce a comparar nuestra población de Peñaflor con otras procedentes de otras regiones y condiciones pero de cronología parecida (vid. infra).

En definitiva, ante una incierta fecha de conquista y colonización cristiana medieval de esta parte de la Meseta Sur, y ante una expedición tan significativa como la de 1213, nuestro estudio en Peñaflor nos permite empezar a conocer dicho proceso y a sus protagonistas desde la materialidad misma del registro arqueológico.

\section{EL ASENTAMIENTO DE PEÑAFLOR}

El cerro Castillón en el que se asentó la aldea de Peñaflor es el espolón final y estrecho de una meseta más grande al Suroeste de Villanueva de los Infantes. De los 800

29 Retuerce, “Cerámica medieval, moderna y contemporánea de Villanueva de la Fuente...”; BENÍTEZ DE Lugo ET AL., "Investigaciones arqueológicas en Mentesa Oretana...", pp. 326-330.

30 EsPadAs, "El yacimiento arqueológico de Jamila..."; EsPADAS ET AL., "El yacimiento Arqueológico de 'Jamila'..."; García Bueno, “Aproximación al conocimiento del yacimiento arqueológico de Jamila..."; MoYA-MALENO, “El 'Entorno Jamila' (Villanueva de los Infantes...”.

31 Moya-Maleno, Jamila.

32 Benítez de Lugo ET AL., "Investigaciones arqueológicas en Mentesa Oretana...”, pp. 329s.

33 IBÍDEM. 
x $300 \mathrm{~m}$ que aproximadamente tiene dicha altiplanicie, este brazo de tierra apenas ocupa los últimos 120 × 30 m más orientales del misma; tiene la particularidad que se trata de la parte más alta de ella, a 883 m.s.n.m, unos metros por encima de un par de promontorios intermedios y a una decena de la cota general. Es, por tanto, su altura como promontorio $30 \mathrm{~m}$ por encima del valle inmediato y su aislamiento -con un istmo que lo une a la meseta- importantes razones a ojos humanos para destacar frente al resto del territorio (Fig. 3).

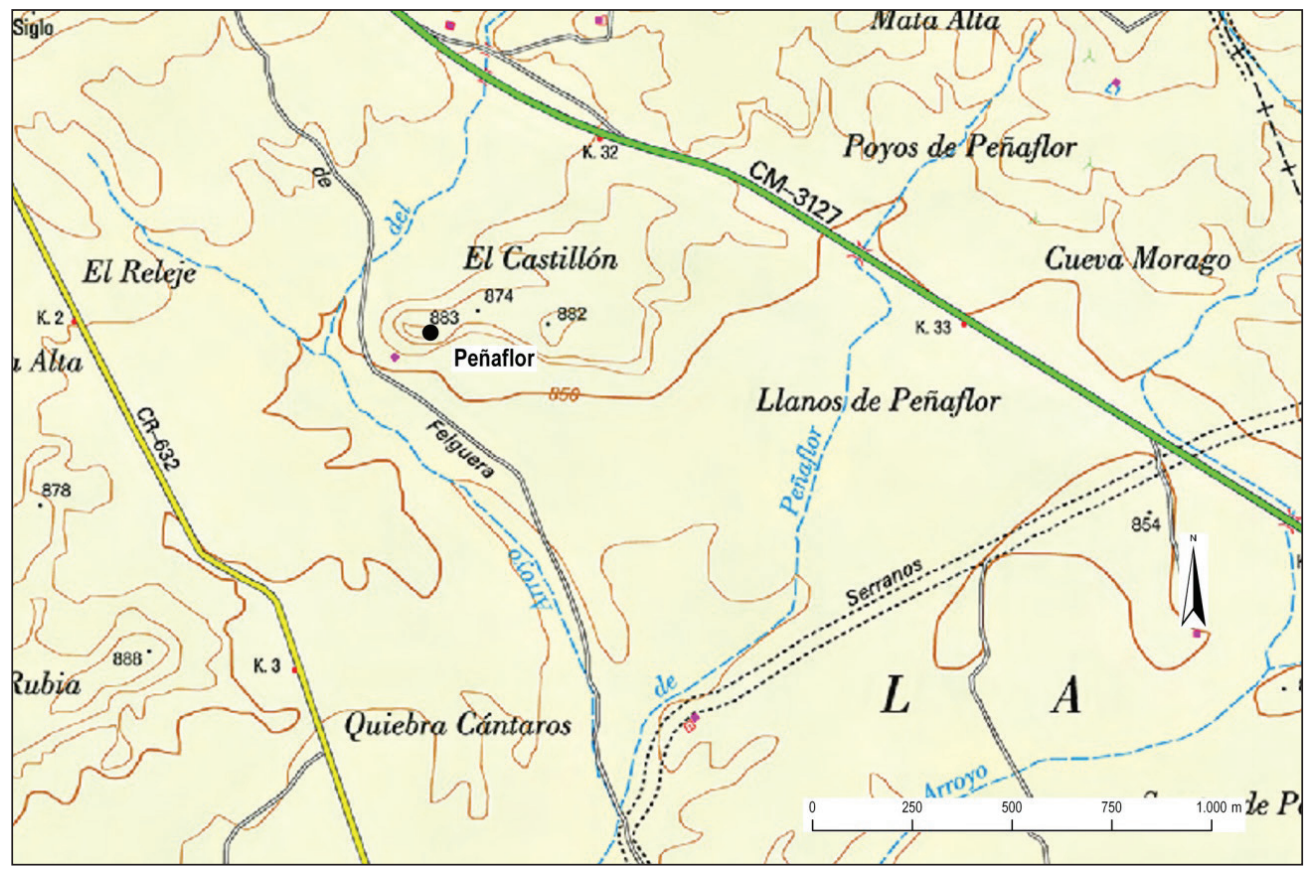

Fig. 3. Topografía y entorno del Cerro Castillón-aldea de Peñaflor. MTN 1: 50000 (retocado).

\subsection{TERRITORIO CIRCUNDANTE}

El cerro Castillón está localizado en el borde Sureste mesozoico sin deformar de La Meseta y su entorno responde a una facies atípica del Trías germánico, propia de bordes de cuencas caracterizadas por presentar areniscas, margas, limos, arcillas y yesos $^{34}$. No se trata de la mayor altura de la zona, pues encuentra cotas similares y superiores frente a él y en sus alrededores ${ }^{35}$ pero, como hemos apuntado, sí es una de las más interesantes para asentarse. De hecho, su aislamiento como espolón viene favorecido por el curso de los arroyos del Toril y el de Peñaflor que lo delimitan por sus flancos Norte y Sur, y también por el Oeste al virar el primero para unirse al segundo.

\footnotetext{
34 MANCheÑo, “Informe sobre posibles riesgos de deterioro por procesos geológicos...”, p. 67.

${ }^{35}$ Cabeza Rubia, a 1 km, 888 m.s.n.m.; El Releje, a 1,1 km, 891 m.s.n.m.; El Toril, a 1,3 km, 903 m.s.n.m.
} 
En lo que respecta a la cobertura vegetal, ya hemos señalado en otros textos ${ }^{36}$ que el paisaje totalmente deforestado de hoy día dista mucho del contemplado y explotado por los pobladores de Peñaflor. Entre otros datos, la mera existencia aquí de una dehesa hasta mediados del siglo XVIII ${ }^{37}$ y las escasas manchas que todavía subsisten de forma aislada en el valle de los "montes baxos de chaparrales" que describiera a principios del siglo XVI H. Colón ${ }^{38}$ proyectan al Pasado un ecosistema de bosque mediterráneo mucho más rico y arbolado. Ahora bien, ello no es óbice para considerar la existencia de parcelas de secano, la roturación misma de algunos parajes adehesados y, sin duda, zonas de huerta y plantaciones arboladas en las riberas próximas: así lo pone de manifiesto un primer análisis de los marcadores de actividad de la población de Peñaflor (vid. infra) y los indicios arqueológicos de almendros en la zona $^{39}$. En definitiva, este marco y confluencia de corrientes, así como la cercanía de manantiales y de cauces más potentes como el propio río Jabalón -siempre visible a tres kilómetros al Sur-, permitirían al emplazamiento medieval de Peñaflor cubrir sus necesidades básicas y satisfacer otros recursos silvícolas y agropecuarios.

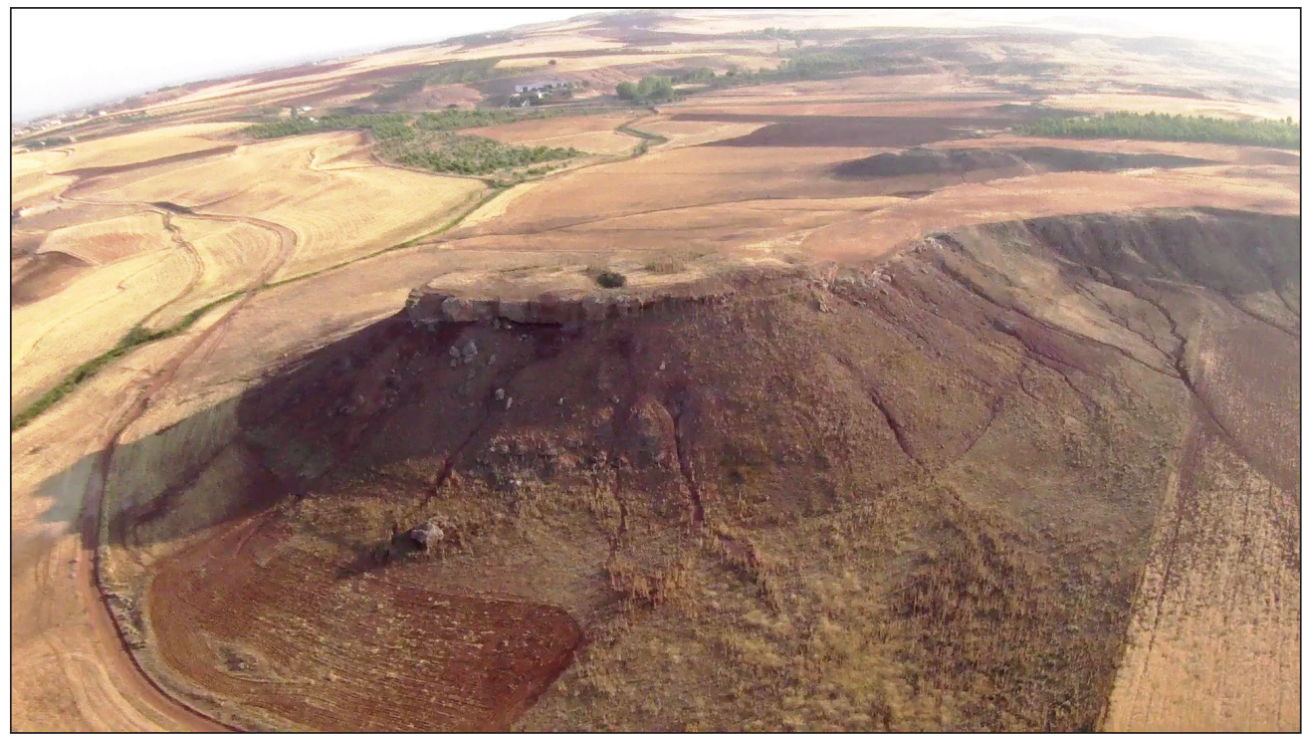

Fig. 4. Fotografía aérea del Cerro Castillón-aldea de Peñaflor: ladera Sur y meseta superior. Foto: Emilio García-PAEJ, 2013.

Otro de los aspectos más importantes relativos al territorio del cerro Castillón es su posición: en primer lugar, avanza dentro del valle del río Jabalón respecto a la terraza anterior -la de Villanueva de los Infantes-; en segundo lugar, ejerce un control directo del cruce de dos vías de comunicación a larga distancia en una comarca

\footnotetext{
36 Espadas y Moya-Maleno, “Un 'Puente Romano’ sobre el río Jabalón...”; Moya-Maleno, Jamila.

37 CAmpos, "La descripción del Partido, Suelo y Campo de Montiel...".

38 Colón, Descripción y Cosmografía de España, p. $127 \S 4507$.

39 Moya-Maleno, " Procesos de reconquista, repoblación y abandono medievales...”.
} 
inherentemente caminera desde la Prehistoria y ligada al importante paso de ganados trashumantes ${ }^{40}$. La Norte-Sur pasaba directamente al pie del espolón para comunicar la Alta Andalucía y La Meseta ${ }^{41}$; la otra, viene marcada por el mismo río Jabalón como un fondo de valle de dos kilómetros de anchura que permite circular Este-Oeste hasta encontrarse con el del río Guadiana, $161 \mathrm{~km}$ más allá.

Autosuficiencia y posición estratégica son aspectos definitivos para entender que durante el surgimiento de las sociedades jerarquizadas aquí se situara uno de los principales emplazamientos calcolíticos de la región ${ }^{42}$, así como que este lugar se reocupara en época medieval (Fig. 4).

\subsection{TOPOGRAFÍA DEL CERRO Y ACCESOS}

Geológicamente, el Castillón es el apéndice final de un relieve tabular coronado por un paquete de areniscas triásicas que preservan parcialmente de la erosión a los materiales, también triásicos, infrayacentes. Estos, presentan una litología a base de arcillas y margas con pasadas centimétricas de areniscas que son más fácilmente erosionables que los suprayacentes ${ }^{43}$. Se trata, por tanto, de un falso paisaje montañoso que parece levantarse sobre la llanura cuando en verdad se trata de antiguas formaciones que han quedado realzadas al erosionarse todo su contexto inmediato.

Las características litológicas y morfológicas del cerro Castillón están afectadas por graves procesos geológicos de meteorización física y química, erosión o gravitacionales que han modificado severamente el aspecto externo tanto de la plataforma superior como de sus laderas. Este proceso de descomposición del cerro es natural y está basado en la reducción de la resistencia interna de las areniscas, alentado por la erosión, el exceso de inclinación de la pendiente, la ausencia de vegetación y las vibraciones del terreno debida a terremotos.

Pero, a tenor de cómo están afectando negativamente a los restos arqueológicos de los que tenemos conocimiento ${ }^{44}$, con un paisaje lunar en la meseta, cayendo bloques enteros de roca (Fig. 5) y llegando a aflorar la roca madre en distintas zonas, podemos concluir que el aspecto del cerro esta sensiblemente alterado, cuando menos, desde la Plena Edad Media. El abandono del asentamiento y, sobre todo, la acción canteril aceleraron la alteración del terreno hasta el punto que hemos de pensar en un cerro quizás menos vertical y una plataforma algo más alta y ancha por alguna de sus vertientes.

${ }^{40}$ Moya-Maleno, “¿Caminante, no hay camino...? Territorio y economía de la Edad del Bronce....".

${ }^{41}$ Espadas y Moya-Maleno, "Un 'Puente Romano' sobre el río Jabalón...". En el siglo XIV esta ruta romana a larga distancia seguirá fosilizada en el siglo XIV como camino de Alhambra a Úbeda: AHN, Uclés, carp. $51, \mathrm{n}^{\circ} 4$.

${ }^{42}$ Espadas ET AL., "El poblado calcolítico 'El Castellón'...”; Íd "Memoria preliminar de las excavaciones..."; Poyato y Espadas, "El Castellón, un importante yacimiento con campaniforme..."; Poyato y Galán, "Las cerámicas del 'grupo Dornajos' de la Mancha Oriental", p. 303; GARRIDO, "El campaniforme en la Meseta Sur...”; Moya-Maleno, "¿Caminante, no hay camino...? Territorio y economía de la Edad del Bronce...”.

${ }^{43}$ MANCHEÑo, "Informe sobre posibles riesgos de deterioro por procesos geológicos...".

${ }^{44}$ Espadas y Moya-Maleno, "Cuando la tierra se abre. Intervención de urgencia en una necrópolis de 'El Castillón'...”. 
Aún asumiendo esta posibilidad, consideramos que, como se ha señalado, los espacios domésticos del asentamiento medieval de Peñaflor se ubicaron en el espolón de la meseta y ceñidos por una muralla o parapeto, formando así un recinto de unas 0,27 ha (vid. infra). Si excluimos el área necropolitana (vid. infra), el poblado no parece extenderse mucho más. A juzgar por las inspecciones oculares que hemos realizado en el resto de la meseta no hemos podido testimoniar elementos que nos hablen de lo contrario. Sólo en la zona inmediata del istmo aparecen algunos restos cuya presencia allí podría estar indicando la actividad humana en esta parte, lo cual, si tenemos en cuenta que se trata del único punto de acceso al poblado de forma directa y por tierra llana, podríamos estar ante el mejor lugar para instalar la puerta principal de la aldea.

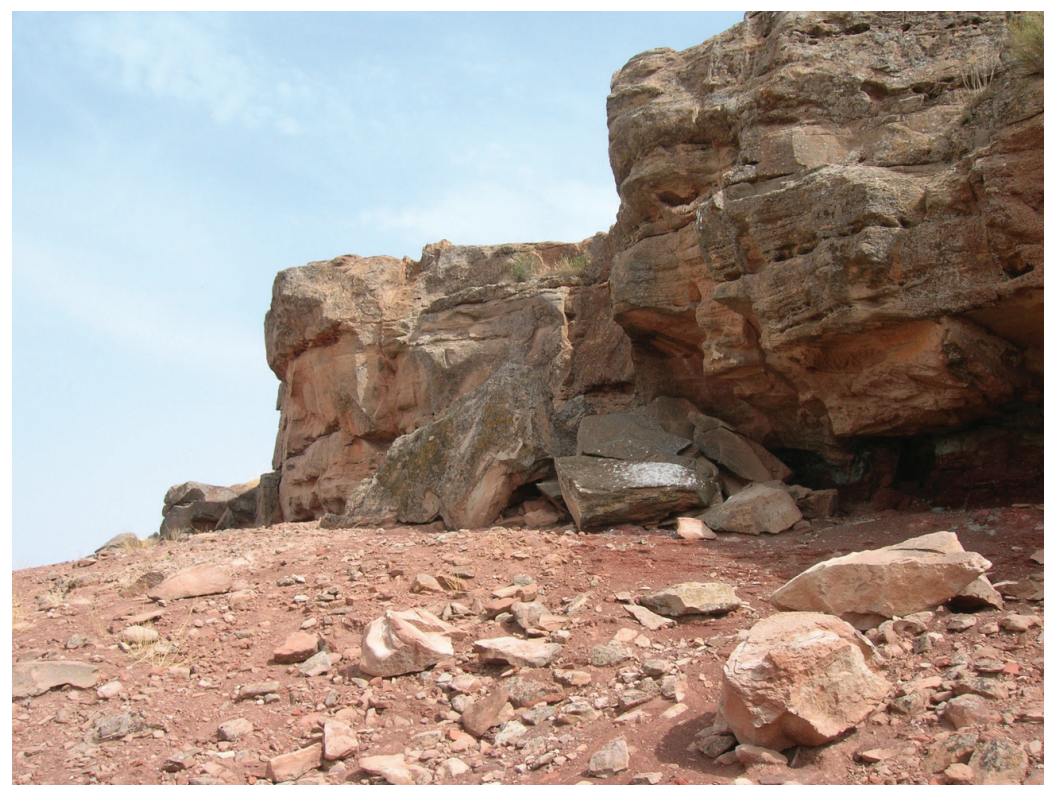

Fig. 5. Desprendimientos de la plataforma arenisca del cerro Castillón en la vertiente Sur y, por ende, posible reducción artificial moderna del perímetro de la aldea medieval de Peñaflor. Foto: PAEJ, 2008.

No obstante, e independientemente de que los materiales allí existentes se deban a una -lógica- actividad de los pobladores en la única parte practicable extramuros, o bien al movimiento de paquetes estratigráficos por deyección de las cotas superiores en las que se sitúa Peñaflor, consideramos poco probable que la puerta estuviera en este lugar. De una parte, es totalmente razonable no situar en el flanco más accesible la entrada a un asentamiento que busca intrínsecamente el aislamiento defensivo a toda costa. Una estrategia de este tipo podría considerarse fallida, pues facilita que las tropas acampadas enfrente tengan acceso directo a la plaza ${ }^{45}$.

${ }^{45}$ Contradecimos, así, lo propuesto por A. Ruibal, "Peñaflor y Saujuolo, dos despoblados cristianos del siglo XIII", p. 674. 
De otro modo, y analizando las otras tres laderas del cerro Castillón, es perceptible que la Norte presenta unas condiciones cuando menos mucho más sugestivas que las restantes. A simple vista, y todavía mejor en condiciones lumínicas o climáticas especiales, como con nieve sobre el terreno (Fig. 6), es posible advertir una rampa que va elevándose desde el Oeste hasta llegar en codo al área del istmo, ya en la meseta. Tal presentación del terreno no parece natural y puesto que su anchura permitiría el tránsito de un carro, puede tener una lectura como camino de acceso principal del poblado.

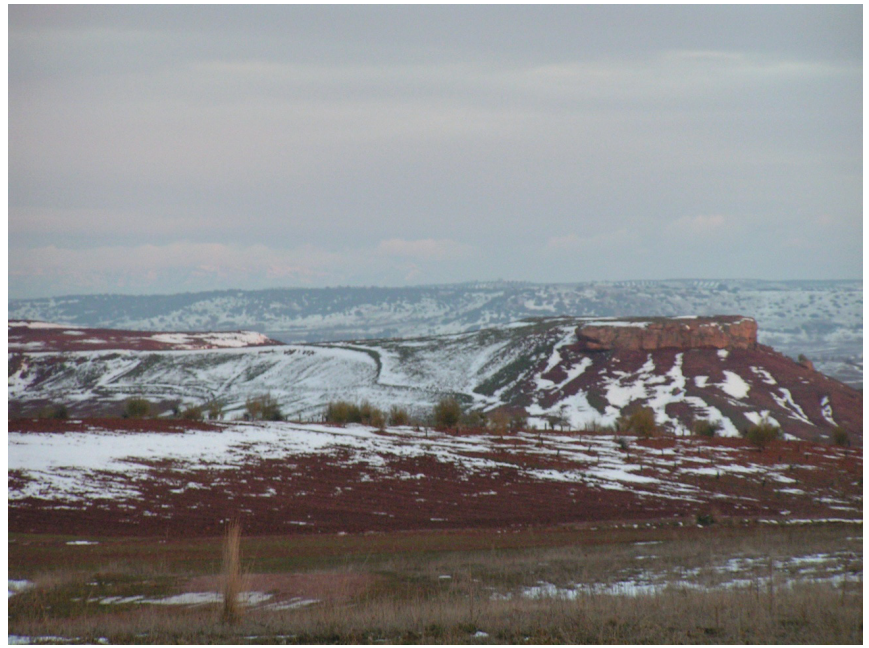

Fig. 6. Frente Norte y Noroeste del cerro Castillón, desde una terraza superior. El efecto de cuajado-deshielo de la nieve podría estar marcando distintas terrazas artificiales a consecuencia de un acceso lateral a la aldea de Peñaflor. Foto: PAEJ, 2006.

Esta posición de la puerta también viene a coincidir con otro aspecto de la poliorcética, puesto que -siempre hablando de escaramuzas y contingentes pequeños-impide irrumpir al asalto el lugar: los enemigos tendrían que atacar en cuesta así como preocuparse en cubrir su flanco más débil, el derecho, con el escudo, con la desprotección y dificultades que ello conlleva.

Con todo, hoy día, es imposible determinar la tipología y localización exacta de la puerta sin excavación previa, puesto que, como ya se lamentara J. González ${ }^{46}$ a nivel general, son pocas las estructuras que pueden discernir sin excavación. Algo similar ocurre en el caso del otro posible acceso que podemos sugerir. De existir, éste podría haberse situado en la parte opuesta a la puerta principal, en la zona Noroeste. Como veremos más adelante, la existencia allí de un paramento y de un rebaje de la roca madre podría haber situado en este punto una poterna que diera salida directamente a una senda menor o bien una ronda al área del cementerio, si no al mismo camposanto.

46 GonZÁlez GonzÁLez, Repoblación en Castilla La Nueva, pp. 244ss. 


\subsection{INTRAMUROS}

El mencionado arrasamiento y erosión de la superficie del cerro apenas permite distinguir estructuras internas correspondientes al urbanismo o a la topografía urbana de la aldea de Peñaflor. En las menos de 0,3 ha que estimamos, no tenemos constancia de planta urbana alguna, ni torres, ni unidades domésticas. Las tres cuadrículas de $4 \mathrm{x} 4 \mathrm{~m}$ realizadas en las excavaciones de los años 80 , correlativas y cercanas al flanco Noroeste, alcanzaron la roca madre en apenas unas decenas de centímetros y sin información relevante al respecto. Así lo demuestran las planimetrías y artículos publicados (Fig. 7).

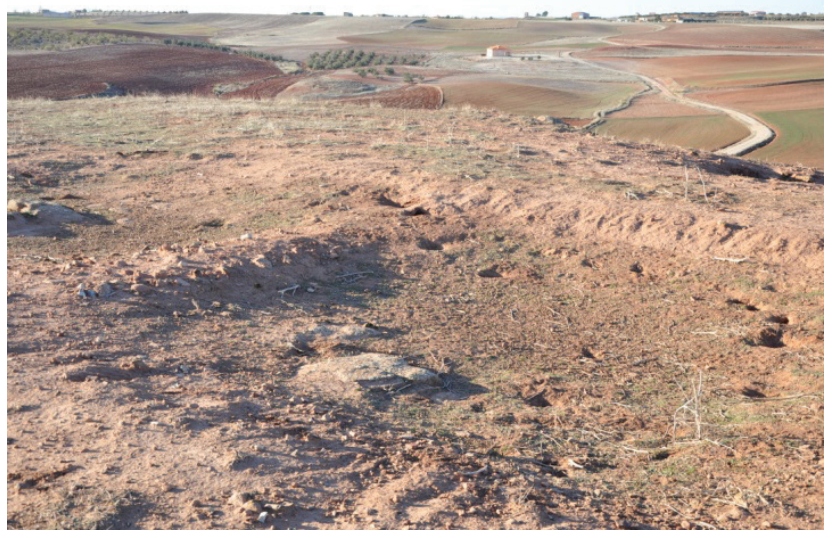

Fig. 7. Catas realizadas en las excavaciones de los años 80 en el interior de Peñaflor. Foto:

PAEJ, 2012.

Hay elementos de juicio para ser optimistas en futuras excavaciones o revisiones del material arqueológico. Por una parte, las tres catas representan un mínimo porcentaje del total del asentamiento y los anteriores arqueólogos estaban centrados en las también importantes cronologías calcolíticas del cerro. Asimismo, existen buzamientos en la zona Sureste que podría albergar hasta un metro de potencia arqueológica, si bien es cierto que pueden estar producidos por la remoción de tierras propia de su fase de cantera.

Tampoco hay que desestimar que estemos buscando un tipo de poblamiento y de arquitectura "en duro" que fuera poco o nada representativa del asentamiento. Las condiciones y causas del encastillamiento podrían haber promovido la construcción de viviendas con materiales vegetales, aunque bien es cierto que ladera abajo aparecen innumerables cascotes de teja curva que, cuando menos, apuntan a un edificio techado con esas características. ¿Sería éste la iglesia que mencionan las crónicas del siglo XIII? Como veremos más adelante, hoy día es imposible conocer su asiento y tipología pero sí se ha de contemplar su existencia intramuros o en la zona de la necrópolis (vid. infra). 
De este modo, la única estructura intramuros adscribible al mundo medieval es el excavado en la roca madre que consideramos cisterna. Esto es así porque la otra gran estructura negativa existente en el cerro, un rectángulo de c. 13 x $4 \mathrm{~m}$ y cuya profundidad -en rampa- alcanza casi dos metros, la consideramos moderna. A pesar de que, tanto popularmente como en las escasas publicaciones al respecto ${ }^{47}$, la señalan como "cisterna", se hallan marcas de cuñas en las paredes rocosas que permiten afirmar que se trata de un frente de extracción de piedra (Fig. 8). En efecto, la rampa ha sido la vía de salida del material a pie de cantera. Y si este espacio fue alguna dependencia o estructura en época medieval nada queda de ella.

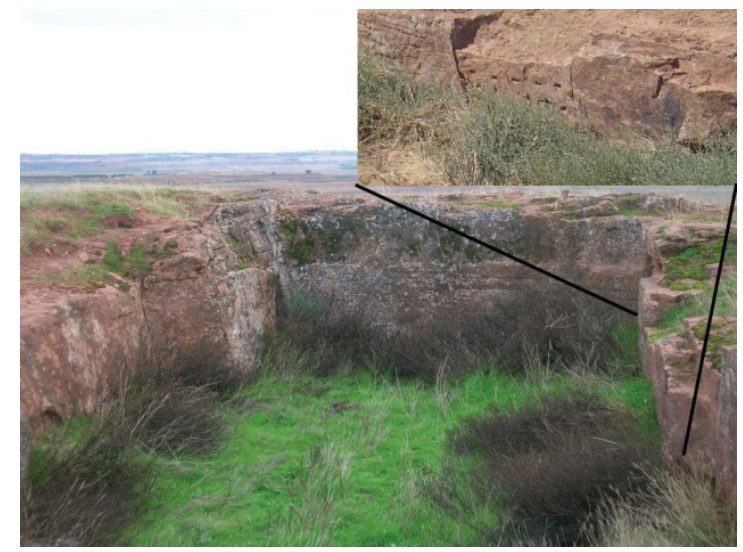

Fig. 8. Cantera en la meseta del Castillón y agujeros para cuñas preparadas para la extracción de grandes bloques de arenisca. Foto: PAEJ, 2012.

\section{Pozo/Cisterna}

La estructura que consideramos pozo-cisterna está ubicada en la zona de estrechamiento del istmo. Consiste en una abertura hexagonal irregular relativamente peque$\tilde{n} a^{48}$ tallada en la roca madre que, según profundiza, ensancha hasta crear una sala subterránea posiblemente circular. Los depósitos de escombros en ella y limos arrastrados por la lluvia impiden definir sus dimensiones originales pero permiten atisbar todavía una única estancia globular con sección de botella (Fig. 9).

Este tipo estructuras negativas se han documentado en otros contextos altomedievales y se han considerado cisternas, como en el asentamiento de Els Altimiris (San Esteban de la Sarga, Lérida) (Fig. 10) ${ }^{49}$. En nuestro caso también la opción de aljibe o pozo es la más factible: primeramente, porque su localización a menor cota que el resto del espolón favorece, bien canalizada, la recogida de aguas de lluvia; su estrecha boca y unas posibles muescas de rozamiento de sogas en sus laterales también

\footnotetext{
${ }^{47}$ Ruibal, "Peñaflor y Saujuolo, dos despoblados cristianos del siglo XIII", p. 673.

${ }^{48}$ Ligeramente curvado en uno de sus lados, su diagonal mayor tiene 2,3 $\mathrm{m}$ y la menor $1,5 \mathrm{~m}$.

${ }^{49}$ Estuvo ocupado entre los siglos V-IX d.C. en la Sierra del Montsec del Pallars Jussá con cabañas diseminadas en torno a una iglesia, quizás monasterio. Se han localizado tres cisternas. SANCHO, "Els Altimiris", pp. 71-78.
} 


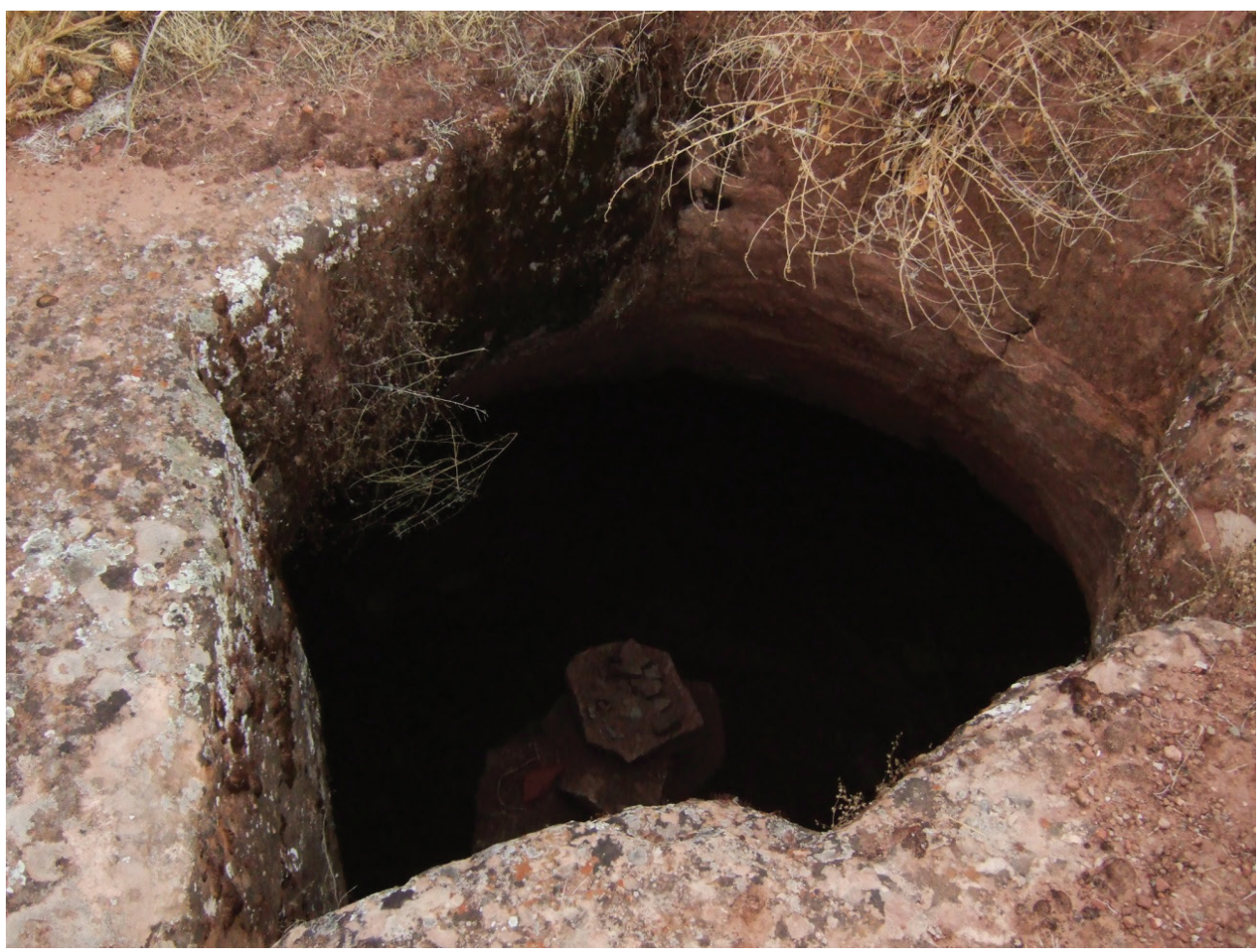

Fig. 9. Vista de la boca y del interior, con escombros, del pozo-cisterna de Peñaflor. Foto: PAEJ, 2010.

estarían marcando una utilidad como pozo (Fig. 9) ${ }^{50}$. En segundo lugar, porque precisamente una de las cualidades geológicas de la arenisca es la porosidad y capilaridad ante el agua, lo cual permitiría regenerar y mantener las reservas más tiempo sólo con la humedad de la tierra y el rezumar natural de las paredes de la sala; por esta razón, cualquier otro uso como silo podría truncar los elementos allí almacenados ${ }^{51}$. En última instancia, teniendo en cuenta la posición encastillada de la aldea, se hace necesaria la existencia de un punto de abastecimiento diario que en un hipotético asedio permitiera prescindir temporalmente del río o manantiales del entorno hasta el fin del sitio.

${ }^{50}$ A simple vista no es posible localizar otros sistemas de canalización o estructuras relacionados con la boca de la cisterna, como en el caso de los canales hacia la cisterna de Els Altamiris y de los agujeros de poste de en torno a ella (Fig. 10): SANCHO, "Els Altimiris", pp. 76 y 78, fig. 7.

${ }^{51}$ Contra Ruibal, "Peñaflor y Saujuolo, dos despoblados cristianos del siglo XIII", p. 674. Igualmente tampoco se asemeja a otros silos islámicos: inter alia, RoJaS y García, "La excavación en la calle San Juan...", p. 16, fig. 6; Ferreira, Mil Anos de Fortificaçoes Na Península Ibérica..., pp. 331. 


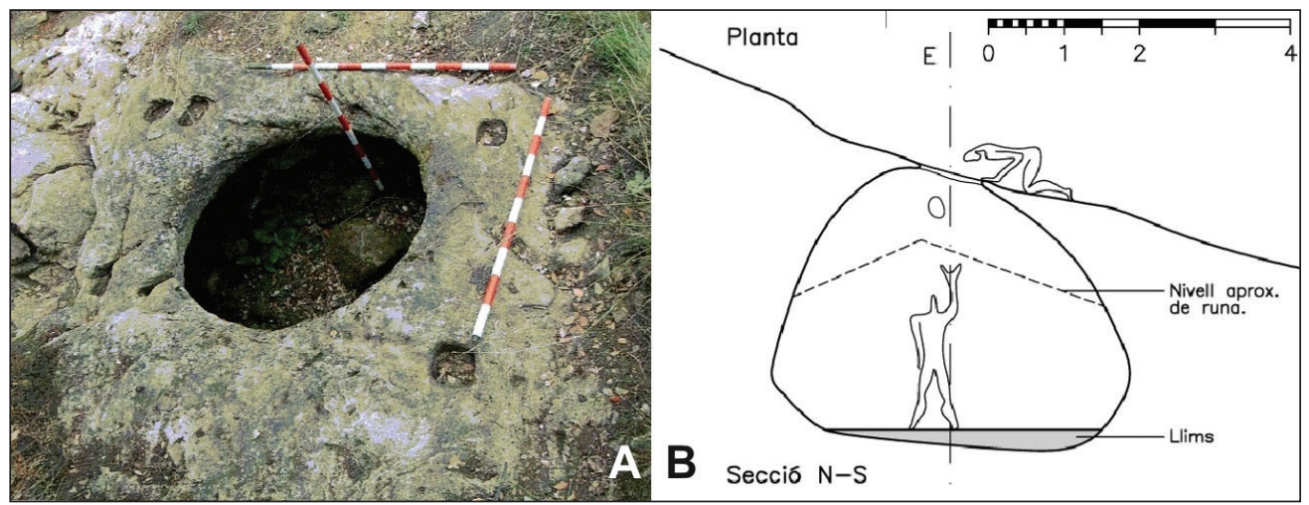

Fig. 10. Cisterna 1 de Els Altimiris (San Esteban de la Sarga, Lérida): A) Fotografía exterior (Sancho, 2010: 78, fig. 7); B) Sección (Altimiris, 2012, recompuesta).

Creemos invalidar así la propuesta de silo de A. Ruibal ${ }^{52}$ y llamar la atención para otras estructuras similares del entorno, como la que también describió el autor en el cerro Saujolo/Sanpolo de Montiel ${ }^{53}$. No obstante, en el caso montieleño la formación caliza de la meseta sí podría haber favorecido otros usos.

Por tanto, tratándose de un elemento de tal utilidad e importancia para una comunidad a la defensiva como la de Peñaflor, hemos de colocar esta cisterna-pozo siempre intramuros. Así pues, es este recurso el que nos ayuda a situar el flanco defensivo oriental, cuando menos, pasado él. A tenor de la ubicación del punto más estrecho del istmo, podríamos llevar la muralla todavía $12 \mathrm{~m}$ más al Este de la boca de la cisterna, pero igualmente sería posible que muralla y cisterna estuvieran contiguas -precisamente como otra forma de entorpecer una posible incursión- aprovechando el progresivo cerramiento de distintos niveles de la roca madre en torno a este punto. Esperamos en un futuro poder estudiar arqueológicamente cualquiera de estas hipótesis.

Igualmente, queda para el futuro realizar un estudio más concreto de la morfología de la cisterna así como cálculos volumétricos. El cómputo de su capacidad será interesante de cara al sustento de la población, pero, en línea con los trabajos de García de Cortázar ${ }^{54}$, también en todo lo relativo a la organización social necesaria para su construcción, mantenimiento y explotación.

\subsection{DEFENSAS}

Un mínimo análisis del emplazamiento y de la arquitectura militar documentada en Peñaflor evidencia la clara intencionalidad de crear un enclave poblacional protegido de ataques exteriores gracias al encastillamiento en un espolón y parapetado al menos por una línea de defensa.

\footnotetext{
52 RuIBAL, "Peñaflor y Saujuolo, dos despoblados cristianos del siglo XIII", p. 674.

53 Í́Í́ p. 677.

54 García de CoRtÁzar, "La organización social del espacio en La Mancha medieval...”.
} 
Si obviamos el mayor o menor efecto disuasorio de los arroyos y la propia verticalidad del cerro, como se ha señalado, una de las primeras estructuras que se conocieron arqueológicamente del poblamiento medieval de Peñaflor, fue precisamente parte de sus defensas ${ }^{55}$. A priori, y a juzgar por las dimensiones documentadas (Fig. 11), se trata, más que de una muralla compleja, de una cerca que reforzaría la fortificación natural del cerro. No puede considerarse una fortaleza, puesto que un contingente bien pertrechado podría dar al traste con la plaza en poco tiempo, y, aunque tampoco se conoce de su perímetro ovalado y composición, los c. $230 \mathrm{~m}$ murados que estimamos - un $8,5 \%$ del asentamiento-, muestran un tipo de asentamiento totalmente desconocido en la zona.

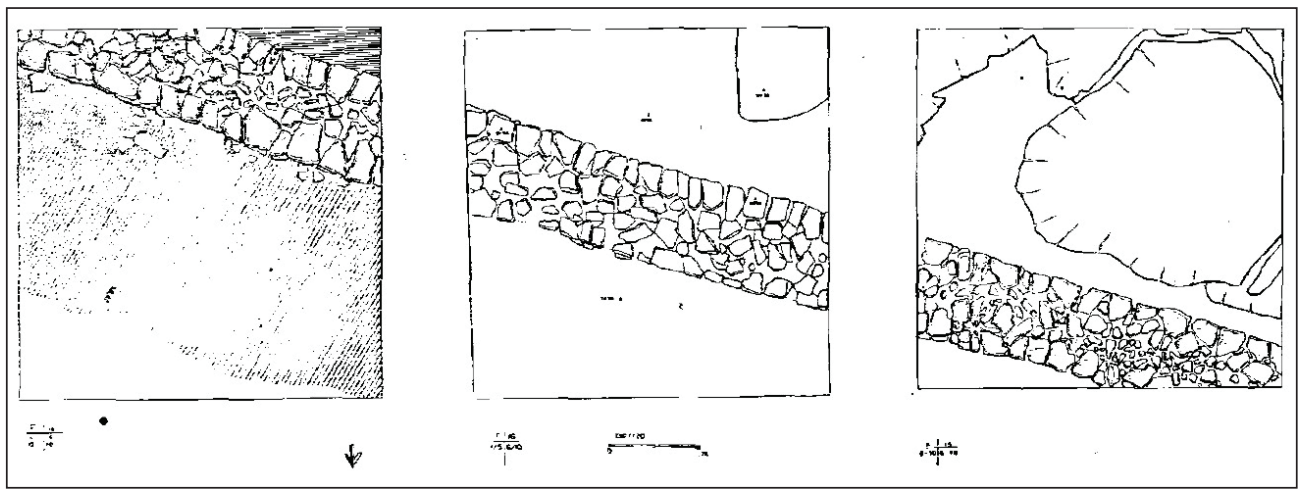

Fig. 11. Planimetría del tramo de cerca exhumado en las campaña de los años 80 , según Espadas et al. (1987: 67, fig. 4).

Hoy día, y quizás no por mucho tiempo más ${ }^{56}$, la cerca exhumada se muestra como un mampuesto corrido con una potencia media de un $90 \mathrm{~cm}$ de altura y uno de anchura. En sus lienzos externos, se trata de un aparejo de través ${ }^{57}$ irregular compuesto por sendos paños de bloques psudorectangulares de piedra arenisca del lugar y dispuestos en unas seis o siete hiladas en seco sin argamasa o, en todo caso, trabadas con la propia arcilla del terreno. En núcleo del parapeto se rellena con piedras de distinto tamaño y tierra. Cada hilada es más o menos regular de tamaño, unos $15-20 \mathrm{~cm}$, para lo cual se insertan piedras más pequeñas para calzar aquellos bloques que no alcanzan la cota deseada. Alguna hilada, como la tercera desde el nivel superior actual, podría considerarse de menor tamaño intencionadamente, pues ronda los $10-15 \mathrm{~cm}$ de altura.

55 Espadas ET AL., "El poblado calcolítico ‘El Castellón'...”, p. 237.

56 Desgraciadamente, desde las excavaciones de los años 80 este muro se está desmoronando progresivamente por la propia acción gravitatoria y por empuje de una mole desgajada de la plataforma de arenisca del cerro desde el interior: EsPADAS ET AL., "Memoria preliminar de las excavaciones...”, p. 68 fig. 5.

57 Nótese que hay algunos bloques en disposición oblicua en la esquina Oeste de la hilada superior del lienzo exterior Norte. Si bien podría argüirse sobre este hecho que se trata de un aparejo en espiga típico almohade -véase Gallego y Lillo, "Estudio arqueológico del Castillo de la Estrella a través...", p. 444-, lo cierto es que no forman hilada, no tienen correspondencia en el lienzo interior e incluso podría considerarse una exfoliación de la piedra. 
No obstante, y a pesar de haberse localizado un posible firme de preparado ${ }^{58}$, creemos que tal estructura sólo constituye un cimiento excavado y rellenado en la ladera Norte del cerro para ganar algo de terreno a la plataforma arenisca de la meseta, pues tal roca madre se encuentra a la misma altura prácticamente que la cota superior de la estructura exhumada (Fig. 12).

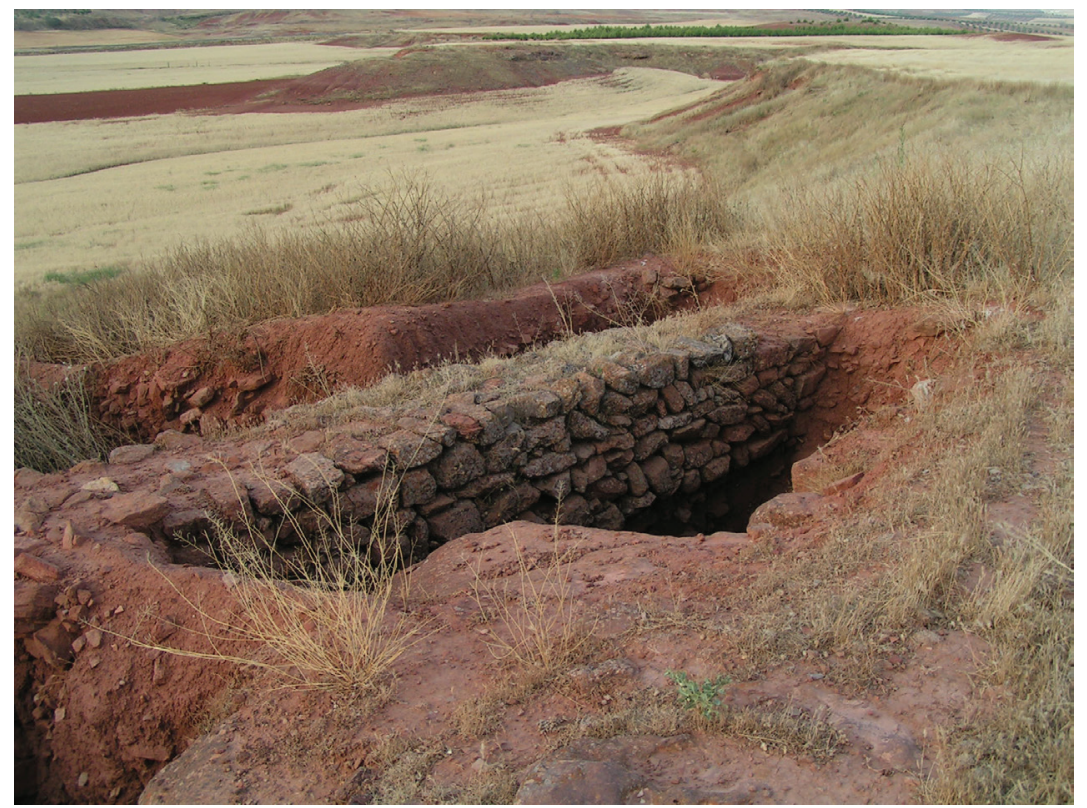

Fig. 12. Cerca de Peñaflor exhumada en los años 80, tramo Norte. Foto: PAEJ, 2004.

En este sentido, es cierto que cabría la posibilidad de que un parapeto pétreo más alto continuara sobre la superficie y que con el tiempo se precipitara ladera abajo, pero tampoco hay que desechar la posibilidad de que éste estuviera compuesto sólo de varias líneas de tapial o de un zócalo pétreo recrecido con tapial. Sea como fuere, la altura de la cerca es uno de los datos que se nos escapa totalmente y cualquier estimación son meras sugerencias, si bien tampoco es descabellado señalar que, a tenor del registro etnográfico y la propia carga de fuerzas, un muro con tales cimientos podría levantar perfectamente una tapia de $3 \mathrm{~m}$ como mínimo.

Aún denominado cerca a este parapeto de mampostería, la morfología de la misma no se corresponde con las también denominadas como cercas de entidades medievales más urbanas ${ }^{59}$ ni tampoco con torres refugio al uso de otros ejemplos del ámbito

${ }^{58}$ Los responsables de las excavaciones de los años 80 lo definieron como "un relleno formado por tierras muy compactas, de color rojizo con abundantes inclusiones de cal, con una potencia que oscila entre los 25 a 30 cms": Espadas ET AL., "El poblado calcolítico 'El Castellón'...", p. 237.

${ }^{59}$ Inter alia, Ferreira, Mil Anos de Fortificaçoes Na Península Ibérica..., pp. 121ss; Íd., Castelos das ordens militares. 
manchego ${ }^{60}$. Más bien encontraría paralelos con las fortificaciones tempranas rurales de tipo castra del mundo tardoantiguo la Meseta Norte -incluso en su función posterior de emplazamiento defensivo ocasional en alto ${ }^{61}-$, pero también hay que llamar la atención de que este tipo de referentes tan alejados no tienen por qué estar implicando relación entre sendas poblaciones sino, más bie quizás, el propio desconocimiento arqueológico existente en contextos más próximos a nuestro yacimiento.

A pesar de que las catas realizadas sólo permiten ver 15,5 $\mathrm{m}$ del parapeto en esta parte, no hay duda que la cerca recorre el flanco Norte de El Castillón a lo largo de aproximadamente unos $80 \mathrm{~m}$ hasta el estrechamiento Este. La lógica protección del lateral septentrional de la meseta del cerro y la observación sobre el terreno de un desnivel artificial así lo muestran (Figs. 11 y 13).

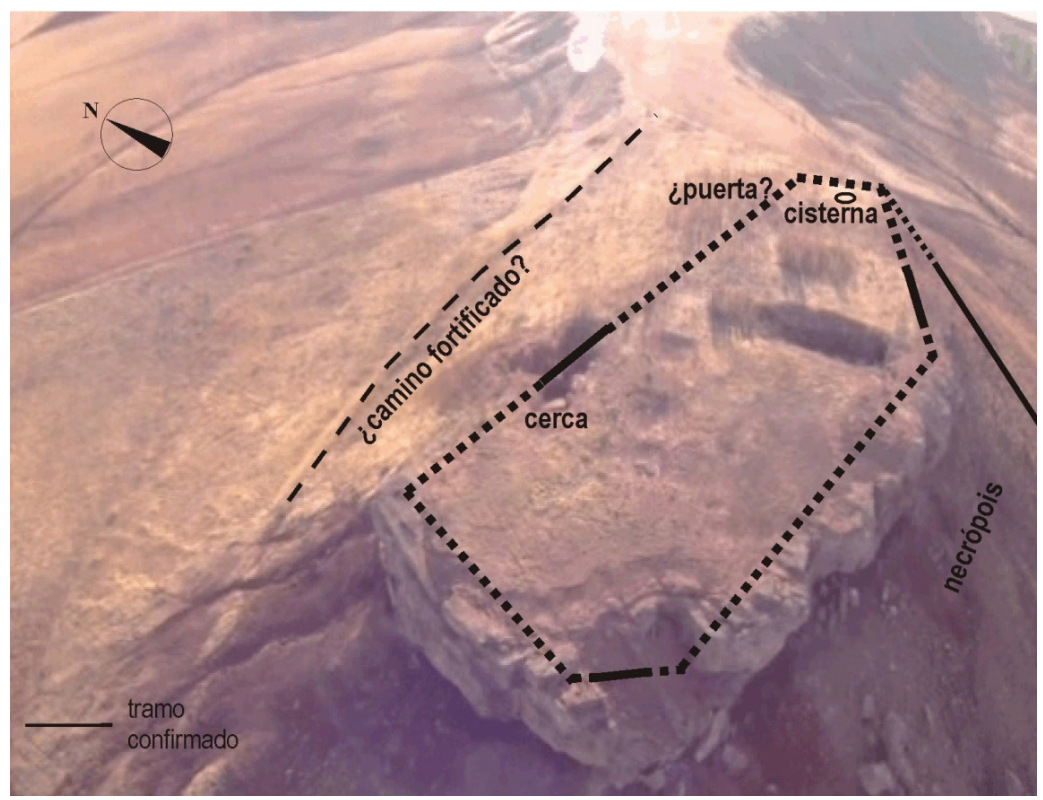

Fig. 13. Hipótesis de las estructuras defensivas y urbanas de Peñaflor, sobre foto aérea (E. García y PAEJ, 2013).

Con independencia de dónde ubiquemos la entrada (vid. supra), la llana orografía del istmo que comunica el espolón del Castillón con el resto de la meseta implicaría fortificar este cuello con un paramento de entre 5 y 20 m de longitud según se situara la defensa justo en el estrechamiento o unos metros más hacia el espolón, pero siempre dejando intramuros la cisterna/pozo (vid. supra). De una forma u otra, y bien situando aquí la puerta o bien un paramento, éste debería ser lo suficientemente

60 Molero, “'Torres refugio' en La Mancha Medieval”.

${ }^{61}$ Martín Viso, Poblamiento y estructuras sociales en el norte de la Península Ibérica..., p. 56, passim; GuTiÉRREZ, "La fortificación prefeudal en el norte peninsular...”, pp. 20s. 
sólido para soportar un ataque directo por este flanco, sin duda el punto mas accesible y débil de todos.

Por su parte, el flanco Sur no es equiparable al Norte. El meridional es la parte más alta del asentamiento y según avanza al Oeste la propia plataforma rocosa crece en grosor y realza la defensa natural de este ala hasta $6 \mathrm{~m}$ sobre la ladera (Fig. 13). Ésta, también con más recorrido por su caída hacia los valles de los arroyos del Toril y Peñaflor y del río Jabalón, hace de su ataque una empresa más complicada.

Tal defensa se acrecienta si tenemos en cuenta la presencia en esta vertiente de la necrópolis de la aldea, puesto que ésta poseía su propia cerca (Fig. 13) (vid. infra). Si bien no podemos considerarla una muralla como tal -ni aguantaría un asedio formal-, no hay duda que, en un contexto de ataque de la plaza, se trataba de una primera línea defensiva para los habitantes, puesto que se alzaba sobre la pendiente y conectaba directamente con el istmo. De esta forma, estratégicamente constituía un sistema que ralentizaría cualquier ataque lateral e impediría un asedio cómodo en torno al istmo, el flanco más fácil para instalarse.

En lo que a la continuación de la cerca principal respecta, ésta no estaría apoyada sobre sedimentos como la Norte, sino que se levantó sobre la roca madre. Así se evidencia a simple vista en otro tramo murado -probablemente el ya advertido por A. Ruibal ${ }^{62}$, en la zona Sureste, entre la cisterna y la cantera (Fig. 13). Esta parte de cerca, de 5,5 m y un par de hiladas visibles, confirma el lógico cinturón de defensivo Sur, el cual cubriría una línea de aproximadamente $120 \mathrm{~m}$ hasta la esquina SW. No obstante, buena parte del trayecto está arrasado y tiene la roca madre aflorada.

En los últimos $20 \mathrm{~m}$ de su tramo más septentrional la topografía del cerro y las estructuras documentadas, parecen albergar otro tramo específico. En este caso, la plataforma aparece cortada y rebajada hasta $2,8 \mathrm{~m}$ al final de la rampa que la une con la parte superior de la meseta. Este hecho, en primer lugar, podría responder a la mencionada función de cantera del cerro, pues así se aprecia en los negativos de extracción de grandes piezas de arenisca (Fig. 14). Sin embargo, sí existe un paramento que cierra el acceso a la meseta en este punto, entre dos y cuatro hiladas formando sin duda un lienzo de cuanto menos 3,7 m de longitud (Fig. 15). No parece lógico fortificarse en altura para luego rematar este punto con apenas unas hiladas, por lo que bien podríamos estar ante el último testimonio de un cierre murado todavía por excavar de unos $8,4 \mathrm{~m}$, hasta encontrar la plataforma principal, que ha caído o que fue desmantelado por la propia cantera.

Otra cuestión es determinar si tal tramo de muro respondería a una poterna o complementaría algún elemento de vigilancia/defensa instalado en esta esquina. En este punto, clave para el control del paisaje y de las rutas que transitaban al pie del cerro Castillón, se halla anexa una especie de plataforma tallada en roca, lo cual podría reforzar la función estratégica del asentamiento. El hecho de no documentar estructuras de piedra aquí, además de la mencionada destrucción del lugar, no impide contemplar otro tipo de construcción en tapial o en madera.

${ }^{62}$ A. Ruibal, "Peñaflor y Saujuolo, dos despoblados cristianos del siglo XIII", p. 673. 

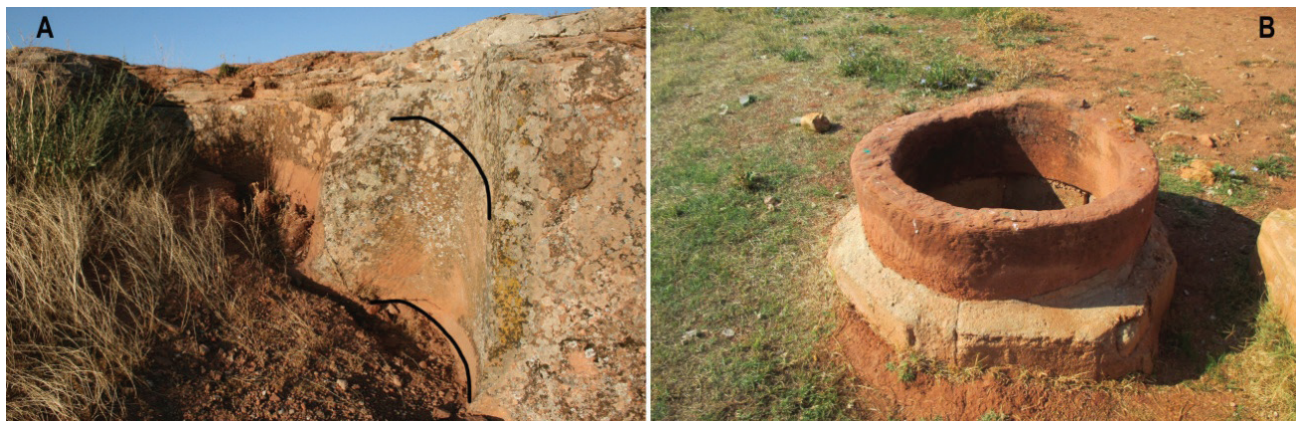

Fig.14. A) Negativo (remarcado) de la extracción de un gran bloque circular del frente Suroeste del cerro Castillón. B) Ejemplo de brocal de pozo en arenisca, procedente de Alhambra, en las inmediaciones del castillo. Fotos: PAEJ, 2014.

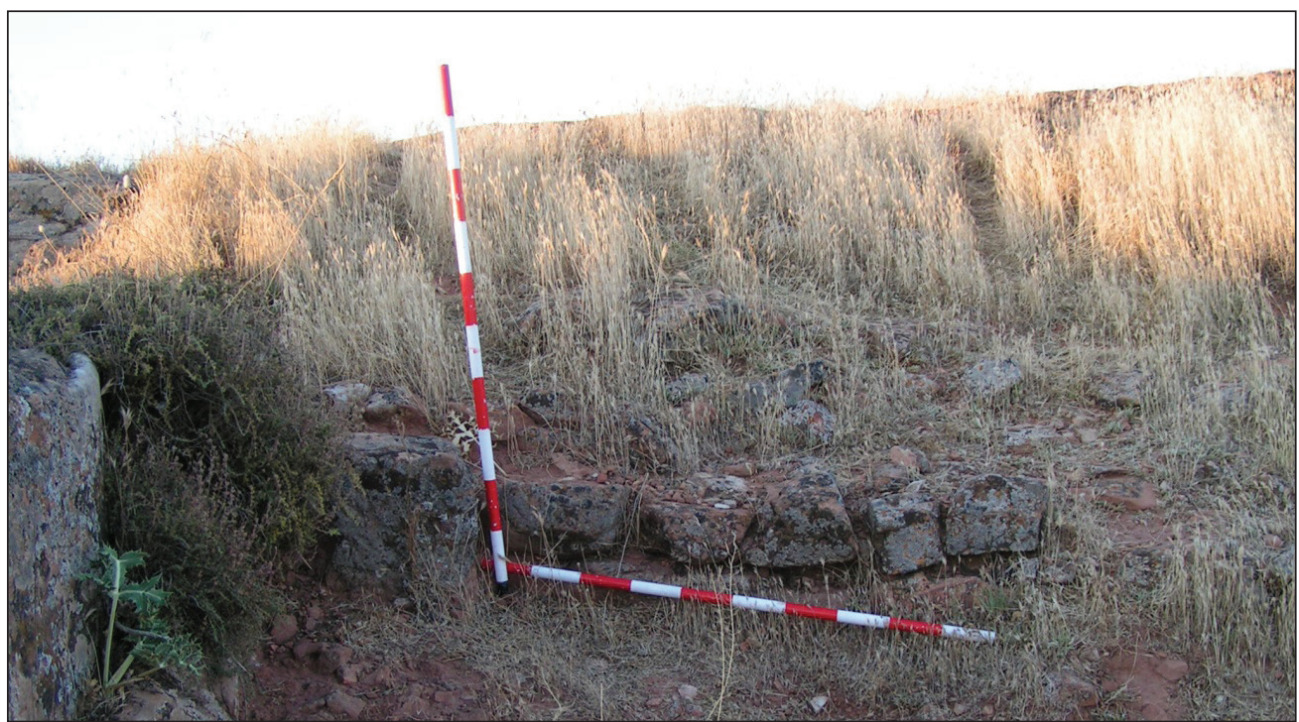

Fig. 15. Posible muro de cierre del flanco Suroeste. Foto: PAEJ, 2004.

Igual que en la mayor parte del flanco anterior, la presencia inmediata de la roca madre al final del espolón impide definir la trayectoria y composición del tramo Occidental. Sólo podemos sugerir que, quizás por tratarse este costado del más vertical, con mayor inclinación del terreno y con menos superficie de ataque, fuera un parapeto menos elaborado o fortificado. Sea como fuere, el muro tendría que cubrir unos 20 $\mathrm{m}$, si no en línea recta, apenas con uno o dos leves ángulos en su itinerario (Fig. 16).

Habiendo finalizado nuestro recorrido por la cerca de Peñaflor que se puede deducir de los distintos tramos visibles, creemos ineludible remarcar su necesaria existencia. En primer lugar, por la propia lógica defensiva de una plaza encastillada; y, en segundo término, por el régimen de vientos que impera en el cerro, puesto que su 
condición de espolón entre distintos valles y corredores, requieren, cuando menos, de paravientos potentes para hacer habitable el lugar.

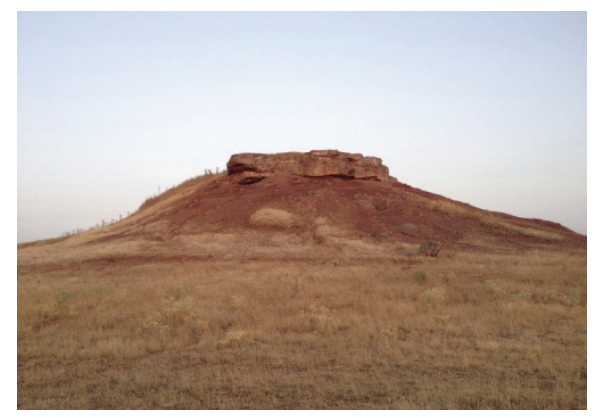

Fig. 16. Frente Oeste de El Castillón desde el pie del cerro. Foto: PAEJ, 2013.

\subsection{NECRÓPOLIS}

Las dos excavaciones que el PAEJ ha desarrollado en el cerro Castillón (2004 y 2013) se han centrado en la necrópolis medieval del poblado de Peñaflor. Si bien en 2007 fue publicado una avance informativo de la primera campaña ${ }^{63}$, es ahora, tras la segunda, cuando contamos con datos suficientes para comenzar a reconstruir el Pasado de este núcleo y el de sus habitantes.

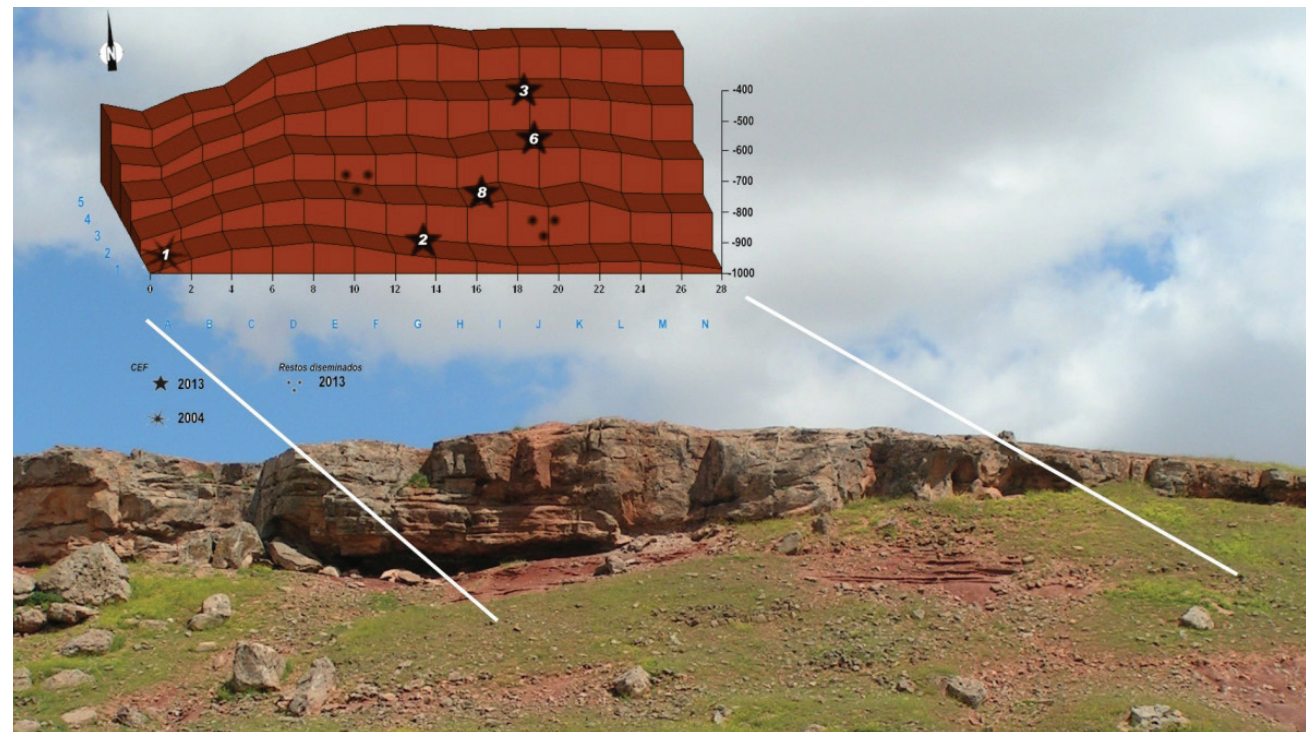

Fig. 17. Necrópolis de Peñaflor en la mitad superior de la ladera Sur del cerro Castillón y representación topográfica con los CEF's intervenidos.

${ }^{63}$ Espadas y Moya-Maleno, "Cuando la tierra se abre. Intervención de urgencia en una necrópolis de 'El Castillón', pp. 381-386. 
La necrópolis localizada e intervenida se sitúa en buena parte de la mitad superior de la ladera Sur del cerro, en lo que, a priori, puede considerarse un terreno poco apto para instalar una necrópolis dada la extremada inclinación de la superficie. Además de esta vertiente pronunciada llama la atención la abundante cobertura de areniscas y margas meteorizadas más que de tierra, que es la que cabría esperar (Figs. 4 y 17).

De una parte, la pendiente se solucionó con un sistema de aterrazamientos en varios pisos a través de un muro perimetral y de contención al Sur. Pero el arrasamiento de terrazas y de tramos enteros del muro, unido a grandes cárcavas y el afloramiento de una endeble roca madre de arcillas prensadas, la cual se disgrega con una leve presión, advierten de la extrema alteración del contexto.

\section{Excavación}

Las excavaciones se realizaron en áreas concretas previamente seleccionadas por su manifiesto estado de degradación y devastación: bolsadas de huesos que afloraban de la tierra y que por dicha exposición a la intemperie también mostraban deshidrataciones severas y pérdidas de volumen. Algunos huesos presentaban todavía conexión anatómica mientras que otros revelaban ya estar en fase de rodado. Lo que, por un lado, constituye un lamentable testimonio del estado de conservación del Patrimonio Arqueológico en pleno siglo XXI, por el otro, y teniendo en cuenta la inexistencia de elementos de señalización originales - piedras hincadas, inscripciones, etc.--, también ha servido para marcar los puntos por donde empezar a intervenir (Fig. 18).
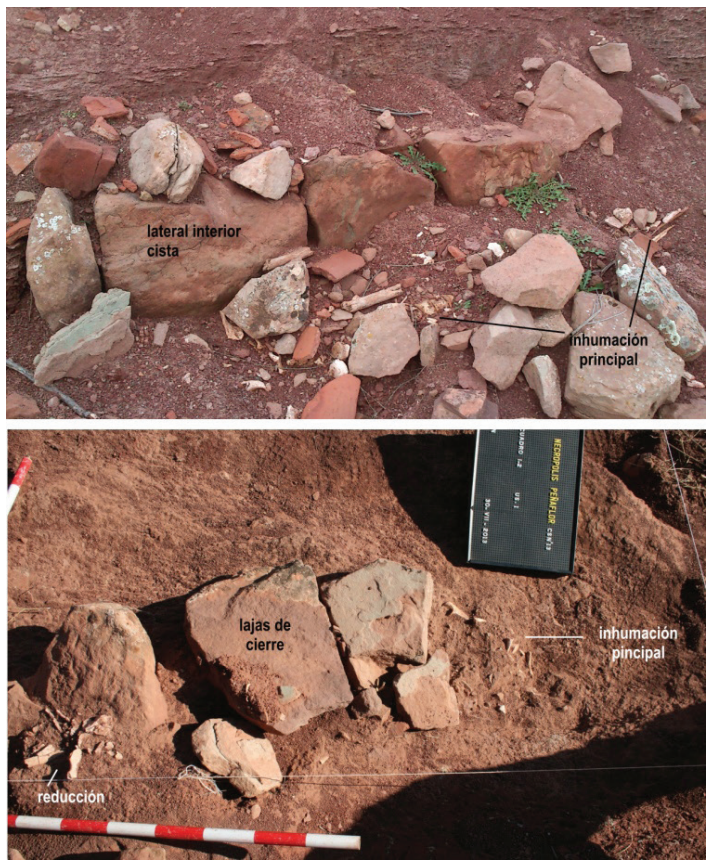

Fig. 18. Estado de los CEF2 (arriba) y 8 (abajo) al inicio de su excavación en 2013. Fotos: PAEJ. 
Dado el nivel de arrasamiento de la ladera Sur -sin apenas sustrato y altamente removido-, y ante las numerosas evidencias optamos por centrarnos en las menos dudosas y en las de mayor accesibilidad. Así es como hemos localizado cinco Complejos Estructurales Funerarios (CEF's), uno en 2004 y cuatro en 2013, los cuales albergan varios enterramientos y distintas tipologías de tumbas como consecuencia de la reutilización y superposición de unas sobre otras ( vid. infra). A cada individuo singularizado durante la excavación se le asignó una Unidad Estratigráfica Funeraria (UF), algunas de las cuales se subdividieron alfabéticamente en laboratorio tras el análisis antropológico, hasta lograr un total de 29 individuos. Como es obvio, este número no representa el total de los individuos inventariados sino el número mínimo de individuos dentro de una muestra heterogénea y mal preservada (vid. infra) (Fig. 19):

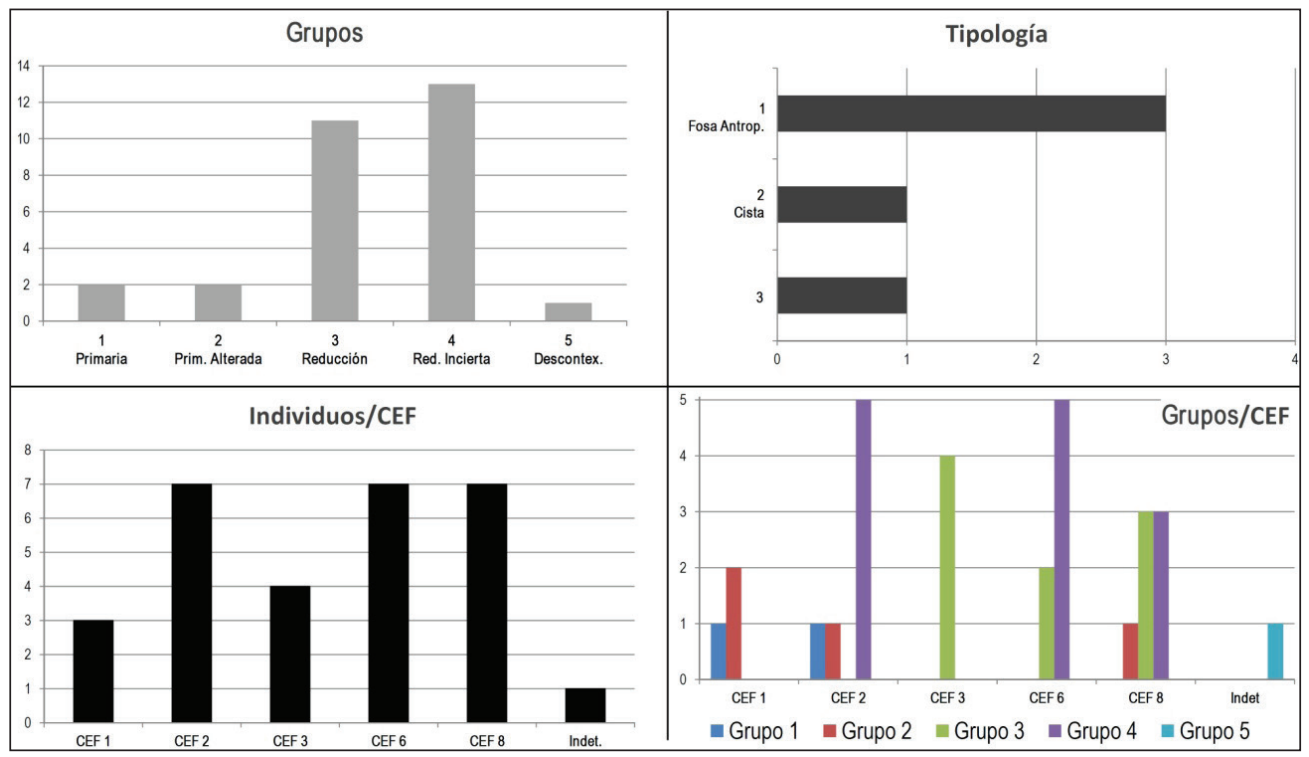

Fig. 19. Gráficas resumen de tipologías, individuos y contextos de la necrópolis de Peñaflor.

- Grupo 1, Individuos completos en posición primaria (2): En sentido estricto los cuerpos localizados en posición primaria y sin alteraciones tafonómicas son sólo dos (CEF1-UF7 y CEF2- UF15).

- Grupo 2, Individuos incompletos en posición primaria semialterados (2): otros dos individuos (CEF2-UF11y CEF8-UF41A), que entrarían en el Grupo 1 de no ser porque parte del conjunto osamentario -tercio superior aproximadamente- ha desaparecido por procesos tafonómicos. Generalmente, el tronco o parte de él y el tren inferior mantienen su posición primaria y sin alterar.

- Gupo 3, Reducciones (11): Restos óseos alterados en su ubicación y número respecto a su posición inicial de inhumación. No obstante, forman contextos arqueológicos cerrados que, aunque más o menos diseminados, siempre están vinculados a un enterramiento posterior junto al cual fueron colocados intencionadamente. Todos los CEF's intervenidos -excepto el 2- contienen reducciones, algunas más evidentes que otras. Se trata a menudo de huesos largos, cráneos y mandíbulas, pero también costillares, 
vértebras, etc. Hay conjuntos claramente distinguibles depositados sobre las losas que tapan inhumaciones principales, como CEF1-UF4A/B; o verdaderos amasijos de varios individuos, como los de CEF6 y CEF3. Pero, especialmente, llama la atención el caso de las tres cabezas (UF43A/B/C) localizadas entre las piernas del individuo del CEF8-UF41A (Fig. 20).

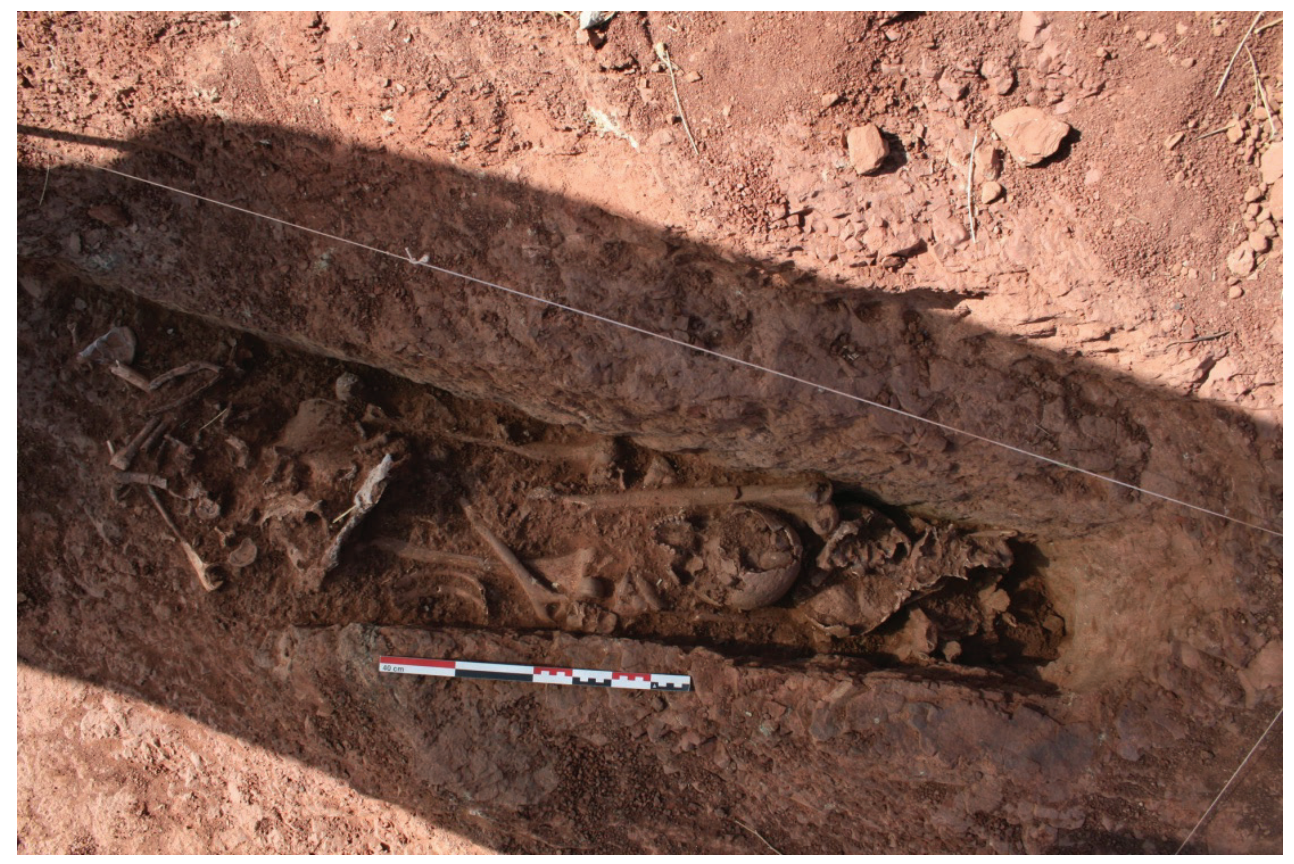

Fig. 20. CEF8 con el individuo principal UF41A y la reducción de otros tres individuos (UF43A/B/C) entre sus piernas.

- Grupo 4, Elementos dispersos, Reducciones inciertas (13): Restos óseos de pequeño tamaño localizados en estratos superiores o en contextos cerrados, como en las fosas (CEF1-UF12), pero en los que muchas veces constituyen el único testimonio de ese perfil antropológico. Aunque hay una alta probabilidad de que sean restos rodantes propios de la tierra con que sepultan al difunto principal, su relación física con el inhumado nos hace aplicar el beneficio de la duda.

- Grupo 5, Restos descontextualizados (1): Huesos y dientes enteros o fragmentados que, fruto del abandono y erosión de la necrópolis vienen rodando ladera abajo, quizás siglos, hasta quedar en los estratos superficiales excavados e, incluso, entrar en contacto con otros CEF's y enterramientos. Son discernibles por la deshidratación y erosión que manifiestan. No obstante, también es posible distinguirlos del resto por una caracterización de número mínimo de individuos (NMI) (vid. infra).

- Grupo 6, Indeterminados: restos óseos cuya adscripción a uno u otro de los anteriores es imprudente, puesto que no existen criterios objetivos para así hacerlo, aunque bien pudieran pertenecer. Suelen ser huesos pequeños y astillados, especialmente procedentes de reducciones o rodantes. 
La tónica general en cuanto a los materiales arqueológicos no óseos inventariados es un registro pobre y descontextualizado. A la inexistencia de ajuares que remarcaremos a continuación, se suma una mínima y revuelta presencia de restos cerámicos, metálicos y líticos rodantes y adscribibles a los dos grandes periodos de ocupación del cerro Castillón: por un lado, fragmentos de cerámica campaniforme y microlitos de sílex de un gran momento calcolítico-Bronce Inicial. Por otra parte, partes de ladrillos y tejas, clavos y cerámicas medievales, generalmente galbos y otros fragmentos rodados, de cuyo examen tampoco define fases estratigráficas. Con todo, a tenor de próximos análisis ${ }^{64}$, sí se puede afirmar la inexistencia de cerámicas de tradición clásica islámica.

\section{Tipología de los enterramientos}

Entre las características de los enterramientos de la necrópolis de Peñaflor, existen una serie de pautas que son comunes a todos ellos y otras características en las que sí es posible establecer diferenciaciones.

Las semejanzas se muestran en el rito mismo de inhumación primaria, pues hallamos que todos los CEF están orientados Oeste-Este, al igual que los individuos allí enterrados, teniendo estos la cabeza al Poniente y los pies al Saliente. Su posición también es homogénea, decúbito supino. Este patrón y la inexistencia hasta la fecha de cipos funerarios discriminan, ya desde un primer momento, la adscripción de la necrópolis a un rito islámico que bien conocemos tanto arqueológicamente ${ }^{65}$ como por la propia canónica musulmana ${ }^{66}$. Por el contrario, coincide con la tradición cristiana de sepultar al occiso de tal forma que al incorporarse el día de la Resurrección, éste mirase de frente hacia el lugar por donde sale el Sol ${ }^{67}$.

Otro hecho en el que parecen coincidir es en la austeridad del rito. Sólo se evidencia cierta acomodación del cadáver, como en otras necrópolis ${ }^{68}$, con almohadillados de piedra tosca; en el caso de la mujer UF41A, bajo los pies. En el caso del CEF2UF15 las piedras sirvieron para rellenar el extremo de una fosa que se hizo más grande que la difunta (Fig. 21).

No se ha documentado adorno, arma o exvoto alguno. Tampoco clavos de los que pudiéramos inferir algún tipo de féretro. Esta última ausencia tenemos que considerarla, cuando menos, lógica, puesto que los contextos más completos eran fosas antropomorfas ceñidas al cuerpo. Dos de los individuos en posición primaria mantienen los tobillos juntos, al igual que los brazos cruzados por las muñecas en el abdomen y pecho, por lo que pudieron habérselos atado. No sucede así en el caso del individuo

${ }^{64}$ Moya-Maleno, “ Procesos de reconquista, repoblación y abandono medievales...”.

65 Delgado Valero, Materiales para el estudio morfológico y ornamental...; Benítez de Lugo ET AL., "Investigaciones arqueológicas en Mentesa Oretana...”, pp. 326ss; RodríGUEz UnToria, "Excavación Arqueológica en Avenida General...", p. 6s.

${ }^{66}$ JuAN ET AL., "Excavaciones de urgencia en el cementerio islámico...", p. 42; RodríGUEZ UNTORIA, "Excavación Arqueológica en Avenida General...", p. 6s; VigIL-EscAlerA, "Sepulturas, huertos y radiocarbono...".

${ }^{67}$ Aurell y Pavón, Ante la muerte, actitudes, espacios y formas...; RuIz TABOAda, La vida futura es para los devotos...

${ }^{68}$ Benítez de Lugo et AL., "Investigaciones arqueológicas en Mentesa Oretana...”, p. 328. RodríGUEZ Untoria, "Excavación Arqueológica en Avenida General...", p. 18. 
femenino UF15 (CEF2), que presentaba la extremidad inferior derecha algo levantada y una mano sobre el vientre mientras la izquierda pegada al cuerpo.

Con tan escasa muestra de individuos en posición primaria no creemos posible sacar conclusiones de estas anomalías, pues puede ser puramente circunstancial. Lo que sí llama la atención y podría entrarse en disquisiciones socioeconómicas o de mentalidad es la coincidencia de la posible preeminencia de los sudarios y la sobriedad con la que se depositó a los finados.

Igualmente, en lo relativo a aspectos materiales, la predominancia de la arenisca local como materia prima de las lajas es total frente a otras piedras, por ahora no localizadas en lo que a construcción respecta.

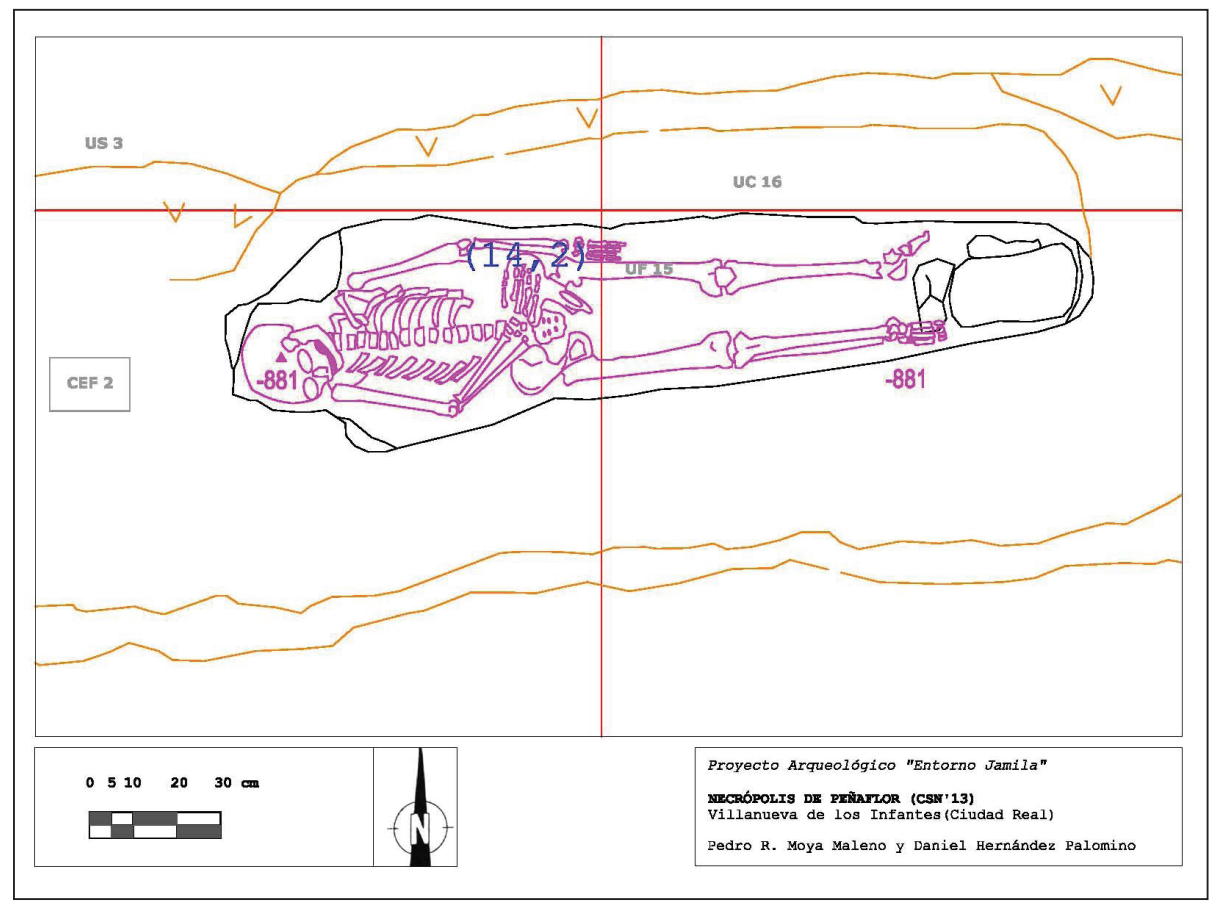

Fig. 21. Fosa antropomorfa tallada en roca de la necrópolis de Peñaflor. CEF2-UF15. Planimetría: PAEJ, 2013.

En cuanto a la morfología de las tumbas sí hallamos distintos continentes para los difuntos. Como en casos anteriores, la tipología que podemos describir hasta el momento es meramente provisional, ya que sólo tenemos documentadas una mínima parte de las que existieron en el cementerio y, en alguno de los casos, como en los CEF3 y 6, cerramos la campaña antes de completar su excavación y poder afinar el tipo de enterramiento realizado. Lo que parece claro ya es su adscripción a población 
cristiana de Repoblación si tenemos en cuenta otras necrópolis de la región con formas semejantes a partir del siglo $\mathrm{XI}^{69}$.

A grandes rasgos podemos señalar tipos bien definidos, cistas y fosas, éste último subdividido a su vez en antropomorfas y ovaladas. Y, quizás, otro tipo a modo de caja construido de mampostería, adobes o arcillas. Lo que parece claro, a juzgar por las posibilidades del terreno, es la inexistencia de cajas exentas insertas en la ladera o levantadas sobre ella. Tampoco hemos documentado enterramientos sencillos en tierra, sin más fosa y cierre que la propia tierra:

- Tipo 1: Fosa antropomorfa tallada en roca madre marcando los hombros y la cabeza. Busca la horizontalidad del fondo para depositar la inhumación principal y se estrecha según se acerca a los pies; una profundidad de $25-40 \mathrm{~cm}$. La pendiente obliga a labrar una cornisa sobre la que apoyan las lajas de entre $15-20 \mathrm{~cm}$ de ancho que hacen la vez de tapa. Cubierta de tierra posteriormente. Ejemplos: CEF1-UC5 (c213 x $100 / 58 \mathrm{~cm}$ ) y CEF2-UC16 (c.280 x 100-60 cm) y, aunque nos haya llegado reventada precisamente la cabecera, quizás CEF8-UC44 (Fig. 21).

- Tipo 2: Cista. Fosa cuadrangular con paredes formadas por lajas verticales de 15$20 \mathrm{~cm}$ de alto por 10-20 cm de ancho. Estaban tapadas también con lajas de 15-20 cm de ancho dispuestas horizontalmente. Busca la horizontalidad para depositar la inhumación principal. Ejemplo: CEF2-UF11. (Fig. 22).

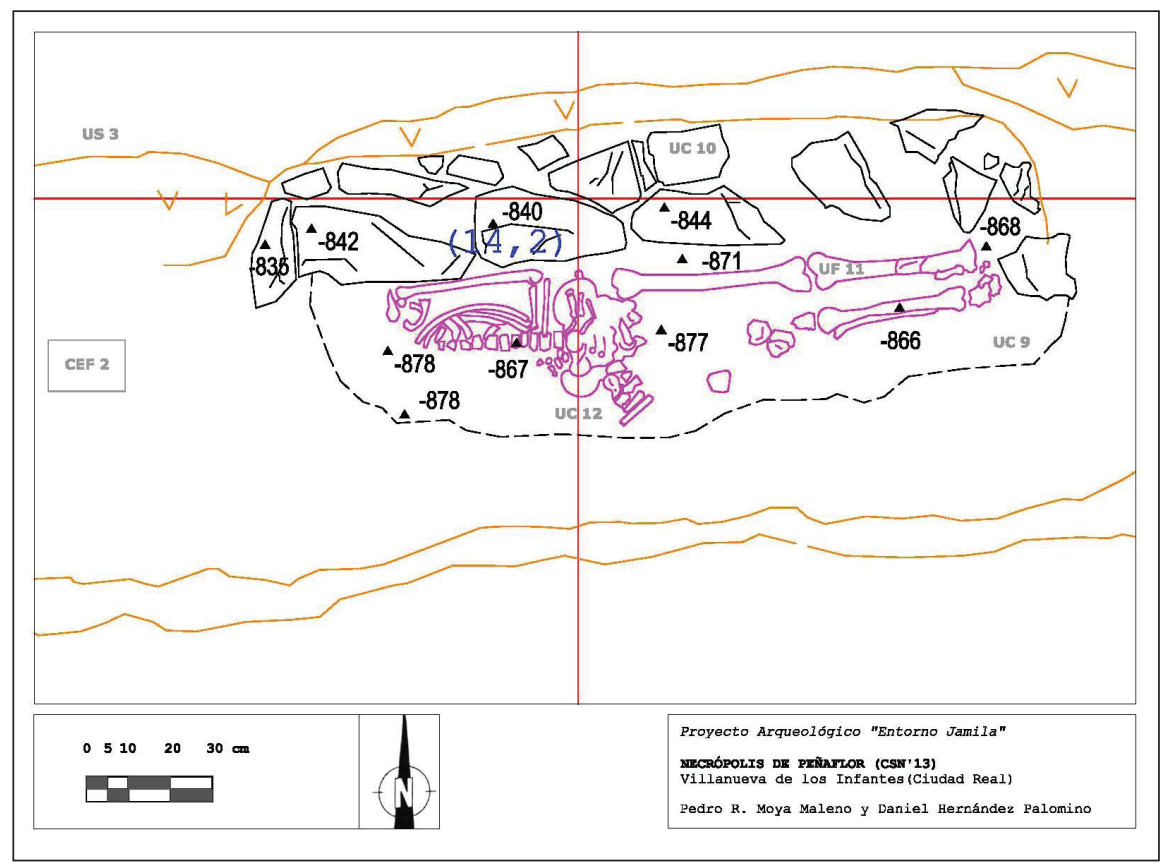

Fig. 22. Cista de la necrópolis de Peñaflor. CEF2-UF11. Planimetría: PAEJ, 2013.

${ }^{69}$ Martínez CAlvo, "Excavación en la necrópolis medieval de la calle Lechuga..."; RodríGUEz UnTORIA, "Excavación Arqueológica en Avenida General...”, p. 11. Ya presentes siglos antes en la Meseta Norte: VigiLEscalerA, "Prácticas y ritos funerarios", p. 268. 
- ¿Tipo 3?: CEF6, como fosa rectangular excavada en tierra cuyo lateral exterior parece reforzado con piedra, arcilla endurecida y/o barro cocido. No se ha excavado en su totalidad, por lo que, además de posibles reducciones, tampoco se ha comprobado la presencia una inhumación principal (Fig. 23).

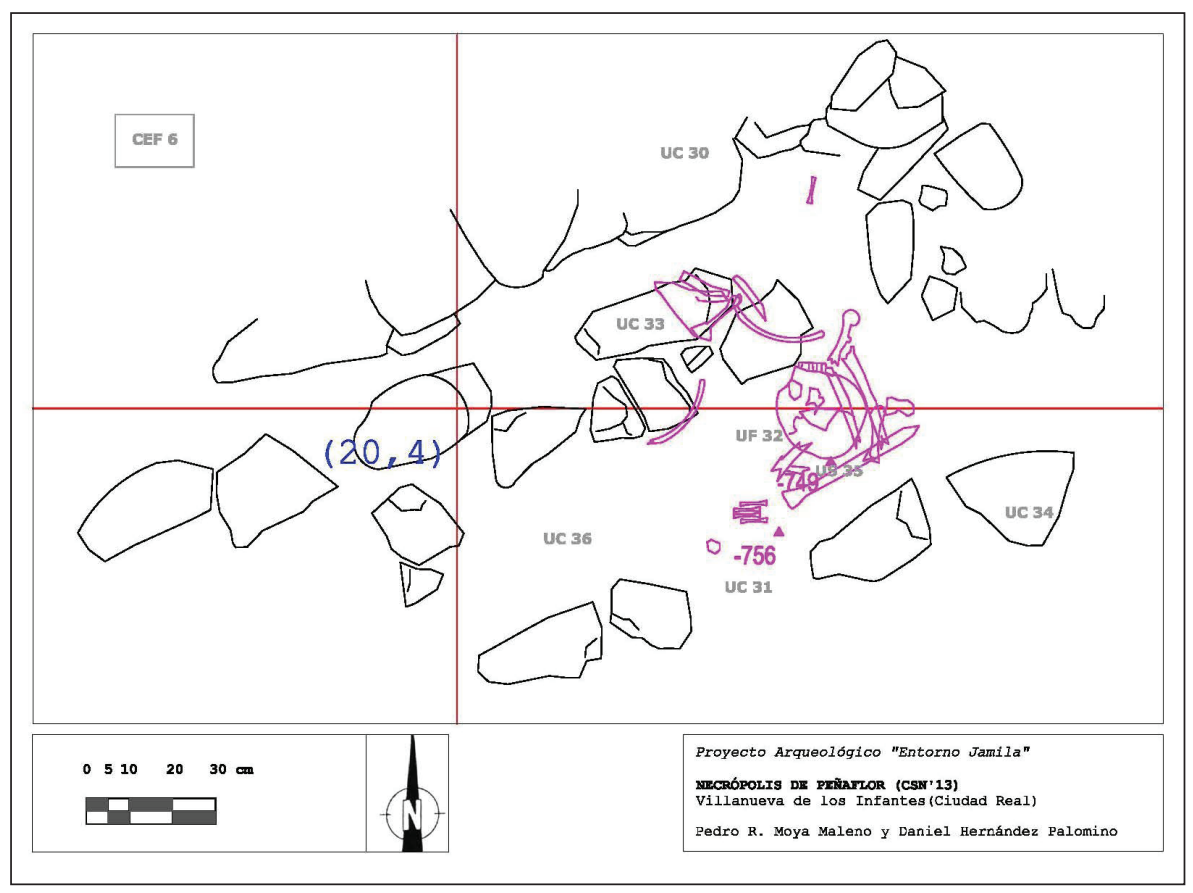

Fig. 23. Posible fosa rectangular de mampuesto en la necrópolis de Peñaflor. CEF6-UC34. Planimetría: PAEJ, 2013.

Con la información de la que disponemos estas diferenciaciones no las podemos considerar étnicas, estéticas o jerárquicas. En especial, creemos que pueden deberse, al aprovechamiento del espacio necropolitano o a la capacidad misma para poder tallar la roca madre, ya sea por causas de adscripción familiar u otras circunstanciales. Esta idea vendría reforzada por la existencia de elementos comunes a todas -anteriormente mencionados-, como la austera inhumación principal y la inclusión de los restos de los antepasados con el nuevo finado en forma de reducción.

Teniendo como ejemplo el caso de la CEF2, donde se inhumó en primer lugar con una fosa tipo 1 y sobre ella se instaló una cista tipo 2 , los motivos familiares o espaciales para superponer enterramientos parecen más que evidentes. De hecho, llama la atención que, si siguiéramos la proporción de tipos en las dimensiones que intuimos para la necrópolis, nos encontraríamos ante un abanico demasiado amplio de formas. 


\section{Planta y recinto necropolitano}

A día de hoy seguimos sin conocer las dimensiones exactas y la planta concreta del recinto necropolitano.

Ante la primera de las incógnitas somos optimistas, puesto que, aunque no hemos localizado los límites laterales del cementerio, sí podemos proponer unas estimaciones mínimas. Una aproximación inicial al tamaño del cementerio está marcada por la distancia entre el enterramiento estudiado en 2004 y los de 2013, lo que aporta en planta un rectángulo de $22 \times 6 \mathrm{~m}\left(132 \mathrm{~m}^{2}\right)$ paralelo a la pared rocosa de la meseta que se levanta en la ladera Sur. Pero será, precisamente, este tope superior rocoso el que nos sirva para inferir un espacio más amplio teniendo en cuenta que el muro exterior oblicuo que ya detectamos en $2004^{70}$ viene a topar con esta pared rocosa en la zona del istmo (Fig. 24). Por ende, siendo lógico adosar el cementerio al flanco natural, y atendiendo al rumbo de tal muro meridional hacia el Suroeste, la necrópolis alcanzaría, cuanto menos, $280 \mathrm{~m}^{2}$ y un perímetro de algo más de $800 \mathrm{~m}$.

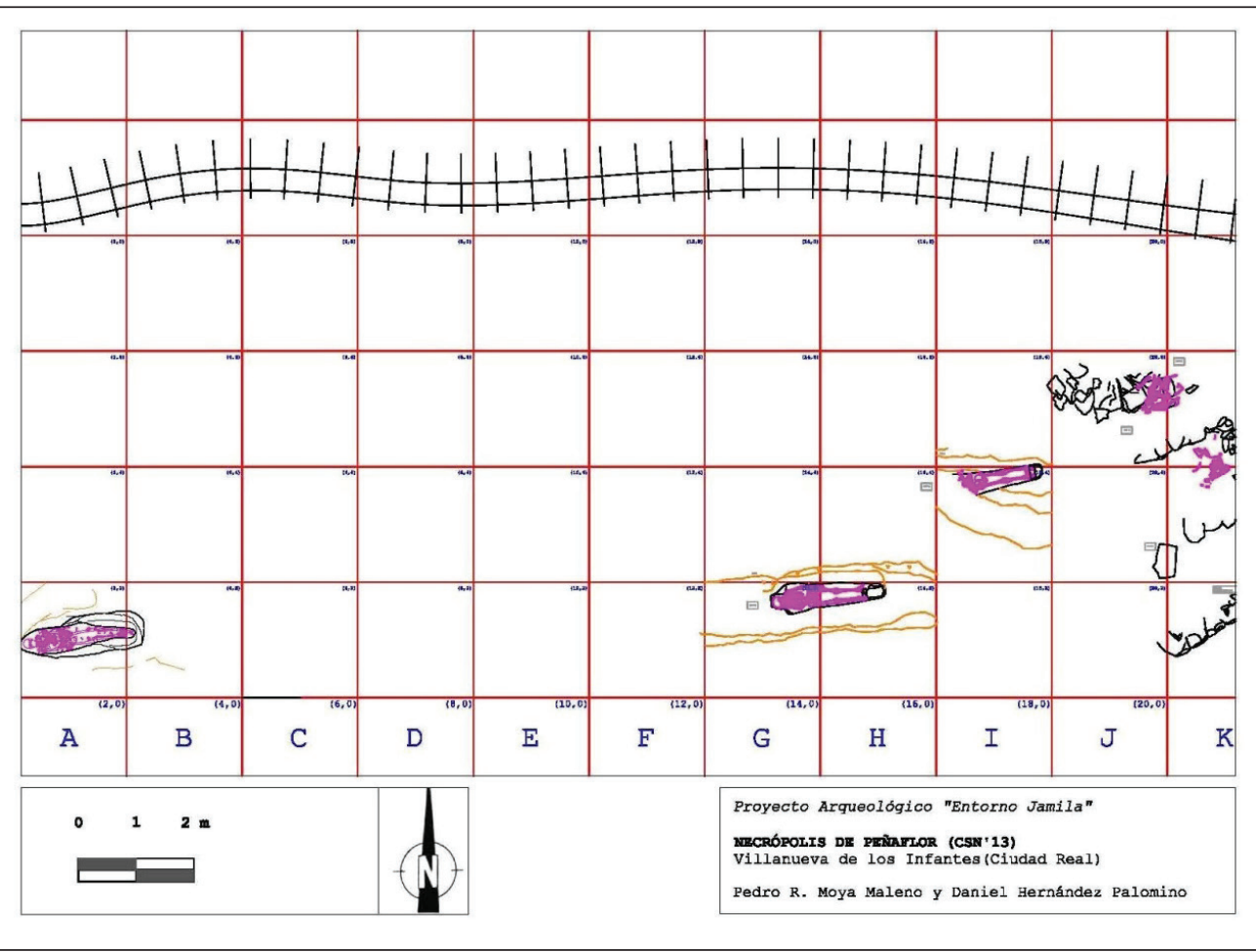

Fig. 24. Planta de la necrópolis con la distribución de los CEF's intervenidos.

El muro perimetral sur (UC 100) es un alineamiento de mampostería formado por varias hileras de piedra arenisca -derruidas- ligeramente careadas al Sur cuya anchu-

${ }^{70}$ Espadas y Moya-Maleno, "Cuando la tierra se abre. Intervención de urgencia en una necrópolis de 'El Castillón', p. 386. 
ra y cara interior todavía desconocemos (Fig. 25). La dirección NE-SW del mismo es patente en el terreno hasta el tramo ahora conocido y, aunque a partir del mismo se corta bruscamente, reaparece unas decenas de metros más adelante formando una curva de nivel artificial. En la parte estudiada - un lienzo de 2,5 m al Sur del CEF6-, el muro se asienta sobre c. $20 \mathrm{~cm}$ de tierra encima de la roca madre, nivel que forma parte del tal proceso constructivo y que se estrecha hacia el NE hasta que la primera hilada apoya directamente sobre la roca madre (US3). En este punto se adosa un segundo cuerpo semejante (UC 101) formado por al menos dos hileras de piedra arenisca ligeramente careadas y con dirección Este. A pesar de que ignoramos otras características del mismo lo consideramos un contramuro exterior (Fig. 26) que podría revelar tempranos problemas de corrimientos en el cerro.

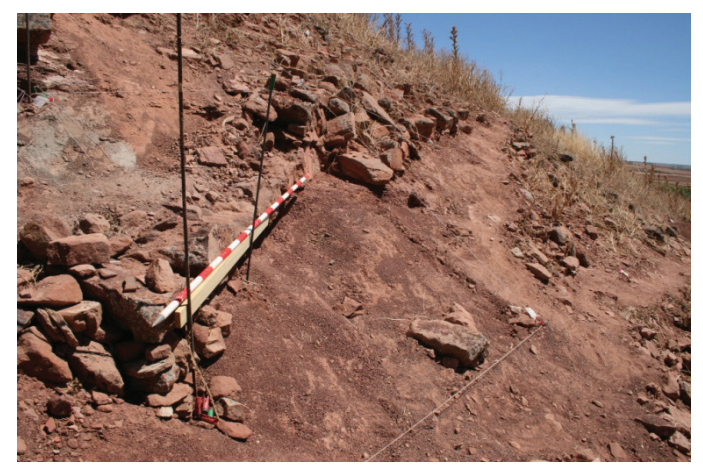

Fig. 25. Muro perimetral Sur de la necrópolis intervenido en 2013.

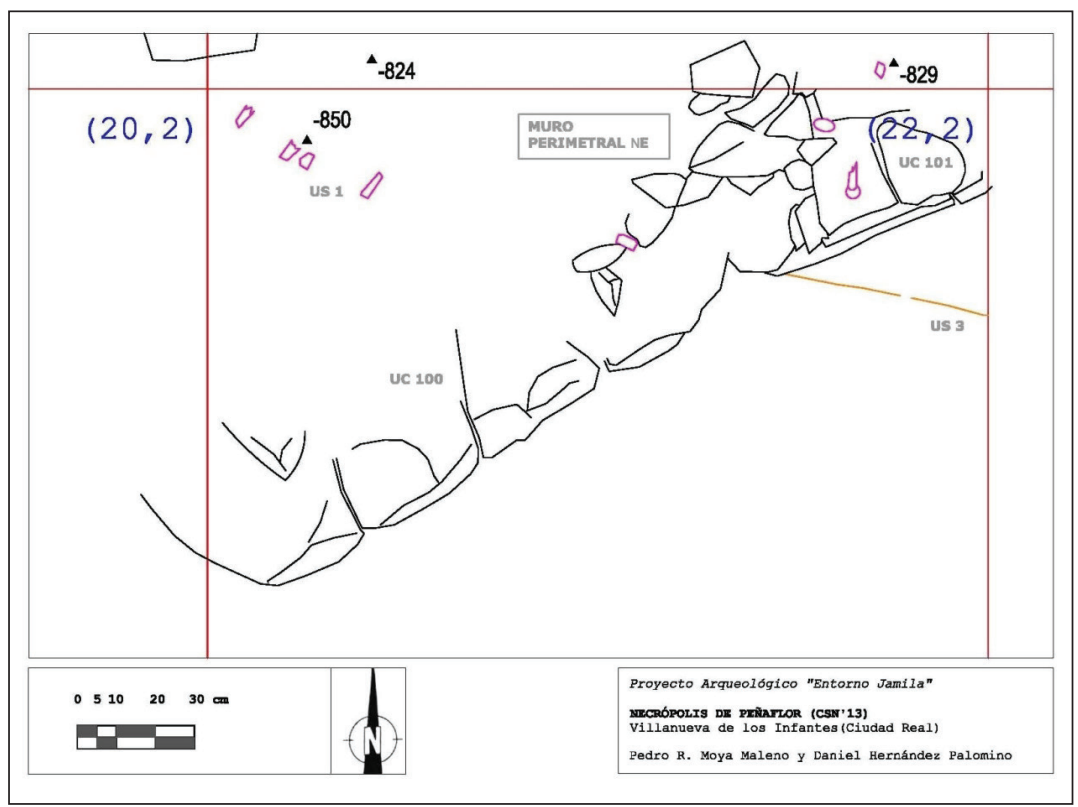

Fig. 26. Planta del muro perimetral Sur de la necrópolis intervenido en 2013. 
En este caso seguimos utilizando como referente Oeste del cerramiento el CEF1 dado que, más allá de él, el terreno está alterado hasta la roca madre y, de haber existido más enterramientos, creemos difícil que se hayan conservado. No obstante, teniendo en cuenta que estimamos estratégicamente imprudente dejar el tramo intermedio SW de la ladera libre, consideramos que bien el muro perimetral de la necrópolis u otro bien pudo remontar hasta llegar a unirse con la cerca superior por la anteriormente mencionada esquina SW (vid. supra) (Fig. 17). Por tanto, en este supuesto, la necrópolis incrementaría su planta de triángulo rectángulo por el cateto menor y doblaría con creces la superficie inicialmente estimada así como el número de difuntos enterrados.

Sea como fuere, el muro perimetral del cementerio tendría a todas luces una triple función: delimitar el espacio de los muertos, aterrazar el terreno e, incluso, servir de línea de defensa avanzada. En el caso del contramuro de refuerzo, lo que por una parte debe considerarse solución estructural a una adversidad topográfica, no hay duda que también estaría reforzando doblemente la seguridad del asentamiento de los vivos. Confiamos en que futuras intervenciones arqueológicas aclararán las características del perímetro de la necrópolis y los puntos de enlace con la cerca de la aldea.

En cuanto a la planta y distribución funeraria de los enterramientos, mucho nos tememos que, aun empezando a atisbar algunas características, es una difícil misión; incluso mediando una excavación total de la necrópolis. Primeramente, porque la erosión ha precipitado los estratos ladera abajo, perdiendo buena parte de las tumbas levantadas sobre la roca madre. La cista reventada UC9 y 10 del CEF2, así lo evidencia (Fig. 22). En segundo lugar, porque directamente la endeble roca madre ha sido deshecha por la erosión hasta el punto de hacer desaparecer partes enteras de fosas, como las cabeceras de CEF1 y 8. De este modo, la deyección homogénea del cerro junto a las cárcavas que han arañado en profundidad la ladera nos hacen perder la referencia de la paleomorfología del cementerio.

Sólo la ubicación y cota de los CEF's intervenidos sí parecen mostrar un patrón aterrazado. La disposición transversal de las sepulturas respecto a la ladera del cerro permite encontrar en su horizontalidad distintas alturas de tallado que, para la propia sustentación de las inhumaciones y acceso a ellas mientras la necrópolis estuvo en uso, necesitaría de un aspecto más o menos escalonado. Así, hasta el momento, los CEF's localizados muestran una correlación en torno al metro de diferencia entre ellos en cuatro pisos como mínimo. Esto sólo pudo ser posible gracias a la contención del muro perimetral Sur por lo que, de seguir tal escalonado hasta él, podríamos suponer teóricamente hasta siete $\mathrm{u}$ ocho niveles de este tipo.

Otra cuestión difícil de dirimir es que toda la necrópolis estuviera totalmente ocupada por los difuntos. A priori la reutilización de tumbas con reducciones y superposiciones parece indicar un problema de espacio y, atendiendo a que el tamaño medio de una fosa ronda los $1,9 \mathrm{~m}^{2}$, un cálculo de ocupación teórica sólo en el área necropolitana intervenida estimaría, cuanto menos, unos 68 enterramientos sólo en este formato.

Evidentemente, cualquier conjetura a este respecto es fútil y atrevida por varias razones. En primer lugar, por la sempiterna desaparición del registro arqueológico en zonas arrasadas; por otra parte, porque no podemos obviar que sean los lazos familiares los causantes de tales reutilizaciones; en última instancia, desconocemos si hubo espacios vacíos destinados a otro uso o, más relevante todavía, algún tipo de estructura religiosa. 
En esta línea, el tema de la existencia de un edificio religioso, tipo templo o ermita, en esta zona de la ladera trae a colación la importante concentración de derrumbes y tejas en la parte superior y central del camposanto de Peñaflor. Con independencia de que se traten de un derrumbe procedente del asentamiento, por un lado, no es descabellado pensar en algún templete rupestre aprovechando las facilidades técnicas que ofrece la pared rocosa a la que se adosa la necrópolis.

Pero, más interesante si cabe, resulta vincular este espacio a la iglesia de la aldea fortificada. No en vano, fue precisamente tal edificio -y los tributos que recaudara en éste y otros asentamientos- lo que llevó a Jiménez de Rada a pleitear por Peñaflor en $1238^{71}$ y lo que nos confirma su entidad como asentamiento formal; un templo que, precisamente, podría tener su ubicación allá donde hoy encontramos los enterramientos de sus feligreses, tal y como fue normal en la tradición cristiana hasta la creación de cementerios específicos en la segunda mitad del siglo XVIII ${ }^{72}$.

Si tenemos en cuenta que para que un espacio ejerciera de iglesia no se necesitaban grandes estructuras, como demuestran otras pequeñas capillas de esta época en la región -como las de Peñarroya o la primitiva de Calatrava la Vieja ${ }^{73}$-, nada impide proponer la ubicación de la iglesia de Peñaflor en esta ladera. Más aún sabiendo de las reducidas dimensiones del espolón en el que se asienta la población ${ }^{74} \mathrm{y}$ de la presión demográfica que se aprecia en las dimensiones de la necrópolis.

\section{ESTUDIO ANTROPOLÓGICO}

\subsection{MATERIAL}

Se han estudiado un número mínimo de 29 individuos pertenecientes a la colección de restos óseos de la necrópolis medieval de Peñaflor, en el cerro Castillón de Villanueva de los Infantes. Su estado de preservación es diverso, siendo en ocasiones, un simple conjunto de esquirlas óseas el que pueda representar a uno de los individuos.

Para la serie de edad adulta la preservación ha sido mejor que para la serie de los individuos infantiles, caso frecuente en las poblaciones de origen arqueológico ${ }^{75}$, aunque finalmente, en su representación numérica, hay una mayor cuantía de individuos no adultos que adultos representados en el número total de la población documentada (Fig. 27).

${ }^{71}$ Lomax, "El arzobispo don Rodrigo Jiménez de Rada...”, § 1, pp. 342-348; GonZÁlez GonzÁLEz, Repoblación en Castilla La Nueva, pp. 356s; Pretel, Alcaraz y su tierra en el siglo XIII, p. 112.

${ }^{72}$ Así se está poniendo de manifiesto en las recientes excavaciones de la iglesia medieval de Montiel, en la falda del castillo, aunque este ejemplo no es comparable ni cronológica ni tipológicamente con el tipo de poblamiento y esencia misma de Peñaflor.

${ }^{73}$ Molina, "Reconquista y repoblación en el Campo de Montiel. Los primeros espacios...".

${ }^{74}$ La planta y dimensiones de otros templos de la época en zonas cercanas, como el de la aldea de Torres, no tendrían cabida en esta ladera. Para Torres: Corchado, Avance de un estudio geográfico-histórico..., pp. 178 s.

75 GonzÁlez Martín ET AL., "La evolución de 'los niños': algunas reflexiones...”. 


\begin{tabular}{|c|c|c|c|c|c|c|c|c|}
\hline & $\begin{array}{c}\text { Individuo } \\
\text { (UF) }\end{array}$ & Sexo & Edad & Patologías & Posición & $\begin{array}{l}\text { Estimación } \\
\text { estatura }(\mathrm{cm})\end{array}$ & Grupo & CEF \\
\hline \multirow{14}{*}{ 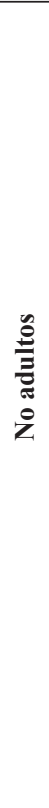 } & 2M4 & A & Indeterminada & - & Secundaria & - & 5 & - \\
\hline & $12 \mathrm{~A}$ & A & Indeterminada & - & Secundaria & - & 4 & 2 \\
\hline & 12B & A & -16 años & - & Secundaria & - & 4 & 2 \\
\hline & $2 A$ & A & Indeterminada & - & Secundaria & - & 4 & 2 \\
\hline & 2B & A & -15 años & - & Secundaria & - & 4 & 2 \\
\hline & $21 \mathrm{~A}$ & A & 15 años \pm 36 meses & - & Secundaria & - & 3 & 3 \\
\hline & $21 \mathrm{C}$ & A & 8 años \pm 24 meses & - & Secundaria & - & 3 & 3 \\
\hline & 21D & A & Indeterminada & - & Secundaria & - & 3 & 3 \\
\hline & $1 \mathrm{~A}$ & A & -14 años & - & Secundaria & - & 4 & 6 \\
\hline & 1B & A & $\begin{array}{c}32 \text { semanas gesta- } \\
\text { ción }\end{array}$ & - & Secundaria & - & 4 & 6 \\
\hline & 43D & A & 12 años \pm 30 meses & - & Secundaria & - & 4 & 8 \\
\hline & 1D & A & 12 años \pm 30 meses & - & Secundaria & - & 4 & 6 \\
\hline & $32 \mathrm{C}$ & A & 11 años & - & Secundaria & - & 3 & 6 \\
\hline & 32D & A & Indeterminado & - & Secundaria & - & 4 & 6 \\
\hline \multirow{15}{*}{ 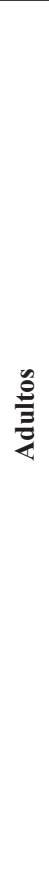 } & $4 \mathrm{~A}$ & M & $35-50$ & Fractura & Secundaria & - & 3 & 1 \\
\hline & $4 B$ & $\mathrm{~F}$ & $18-35$ & - & Secundaria & - & 3 & 1 \\
\hline & 7 & M & $18-35$ & $\begin{array}{c}\text { Infección. } \\
\text { Fractura }\end{array}$ & Primaria & 174 & 1 & 1 \\
\hline & 15 & $\mathrm{~F}$ & 45 & $\begin{array}{l}\text { Caries. } \\
\text { Artritis }\end{array}$ & Primaria & 158,94 & 1 & 2 \\
\hline & 11 & M & 20-29 años & Artritis & Primaria & 157,54 & 2 & 2 \\
\hline & $12 \mathrm{C}$ & A & (Adulto) +18 años & - & Secundaria & - & 4 & 2 \\
\hline & 21B & A & 33-45 años & Artritis & Secundaria & - & 3 & 3 \\
\hline & $32 \mathrm{~A}$ & M & 30-40 años & $\begin{array}{l}\text { Proceso } \\
\text { infeccioso }\end{array}$ & Secundaria & - & 3 & 6 \\
\hline & 32B & $\mathrm{F}$ & (Adulto) +18 años & - & Secundaria & - & 4 & 6 \\
\hline & $41 \mathrm{~A}$ & M & (Adulto) +18 años & $\begin{array}{l}\text { Artritis. Her- } \\
\text { nia. Fractura }\end{array}$ & Primaria & - & 2 & 8 \\
\hline & 41B & $\mathbf{A}$ & (Adulto) +18 años & - & Secundaria & - & 4 & 8 \\
\hline & $43 \mathrm{~A}$ & $\mathrm{~F}$ & $18-25$ años & - & Secundaria & - & 3 & 8 \\
\hline & 43B & A & +50 años & - & Secundaria & - & 3 & 8 \\
\hline & $43 C$ & $\mathrm{~F}$ & (Adulto) +18 años & - & Secundaria & - & 3 & 8 \\
\hline & $43 E$ & A & (Adulto) +18 años & - & Secundaria & - & 4 & 8 \\
\hline
\end{tabular}

Fig. 27. Caracteres antropológicos relevantes a nivel individual de la necrópolis del Castellón. UF: unidad estratigráfica funeraria; M: masculino; F: femenino; A: alofiso. CEF: complejo estructural funerario. 


\subsection{MÉTODO}

Para cumplimentar los objetivos propuestos al inicio de este análisis y posterior investigación se han utilizado diferentes metodologías de las que se ha de dar constancia en esta publicación. Entre las valoraciones antropológicas analizadas, destacan la estimación de la edad, el sexo, la estatura, los marcadores de actividad y paleopatologías.

La edad ha sido estimada a partir de los métodos usuales en antropología física basados en la erupción ${ }^{76} \mathrm{y}$ desgaste dental ${ }^{77}$ (teniendo en cuenta posibles imprecisiones por motivos ajenos al investigador como la alimentación o uso de las piezas dentarias como herramientas), morfología y desarrollo de la sínfisis púbica ${ }^{78}$, osificación y maduración de los huesos ${ }^{79}$, desarrollo y morfología del cuerpo vertebral ${ }^{80}$ además de la estimación basadas en la fusión de las suturas palatinas ${ }^{81} \mathrm{y}$ craneales $^{82}$.

El sexo ha sido estimado a partir de la morfología pélvica ${ }^{83}$ y caracteres craneales ${ }^{84}$. En los individuos no adultos esta estimación se ha desechado por falta de preservación y principalmente, por la asuencia de desarrollo de los caracteres sexuales a nivel osteológico, que impiden la aplicación de métodos fiables de determinación del $\operatorname{sexo}^{85}$.

Los marcadores de actividad han sido analizados en aquellos individuos que se han preservado al menos en un $50 \%$ de su conjunto osamentario (piezas completas o cuasi completas), utilizando metodologías de estudios precedentes ${ }^{86}$. Se han valorado

76 Ubelaker, Human Skeletal Remains.

77 MiLes, "Dentition in the estimation of age".

78 Buikstra y Ubelaker, "Standards for data collection from human skeletal remains".

79 SCHAEFER ET AL., Juvenile osteology.

80 Burns, Forensic anthropology training manual.

${ }^{81}$ Gruspier y Mullen, "Maxillary suture obliteration: A test of the Mann method".

82 ACSAÁDI y NEMESKÉRI, History of human life span and mortality.

${ }^{83}$ FerEmBACH ET AL., "Recommendations pour déterminer l'âge le sexe sur le squelette"; BuIKSTRA y UBELAKER, "Standards for data collection from human skeletal remains".

${ }^{84}$ Herrmann et Al., Prähistorische Anthropologie; FEREMBACH ET AL., "Recommendations pour déterminer l'âge le sexe sur le squelette".

${ }^{85}$ Serrulla, Recomendaciones en antropología forense; Molina, La infancia en el Bronce de La Mancha...

${ }^{86}$ Al Oumaoui ET AL., "Markers of activity patterns in some populations of the Iberian Peninsula"; CAPASSO ET AL., Atlas of Occupational Markers on human remains; CoRIOLANO ET AL., "Anatomy and Functional Architecture of the Anconeus Muscle"; CRUZ ET AL.., "Estudio de los marcadores de actividad de los restos recuperados de la Mezquita..."; Estévez, Marcadores de estrés y actividad en la población guanche de Tenerife; GALtÉs ET AL., "Marcadores de actividad en restos óseos"; ID "Atlas metodológico para el estudio de marcadores músculo...", Dutour, "Entesopathies (lesions of muscular insertions) as indicators of the activities...", JimÉnez Brobeil ET AL., "Actividad física según sexo en la cultura argárica. Una aproximación..."; LAPUENTE, Características Biológicas de la Población de La Encantada...; Proyecto Fin de CArrera: Biología EvoluTIVA y Biodiversidad; SANTANa, El trabajo fosilizado: patrón cotidiano de actividad física ...; MARTín-FlóRez, "Caracterización antropológica de dos poblados de la Edad del Bronce de la Península Ibérica: el Castellón Alto y la Motilla del Azuer"; ViLlote ET AL. "Enthesopathies as Occupational Stress Markers: Evidence from the Upper Limb"; LAFrAnchi, "Patrones de actividad en la Motilla del Azuer: un estudio a partir de restos óseos"; Robledo, Dieta, indicadores de salud y caracterización biomorfológica de la población medieval...; SAntana, "Marcadores Óseos de actividad Física en la Población aborigen de Gáldar...”, LóPez-Bueis, "Mar- 
un conjunto de 71 marcadores de actividad localizados en las entesis ${ }^{87}$ de los tejidos tendinosos sobre la cortical ósea de los huesos largos, clavículas, rótulas, escápulas, pelvis y calcáneos (Fig. 28). En estos lugares se producen transformaciones debido a la acción del sistema muscular. Los criterios de cuantificación se han basado en su presencia, patología, ausencia o que no fueran observables por motivos de preservación del hueso o alteraciones tafonómicas severas.

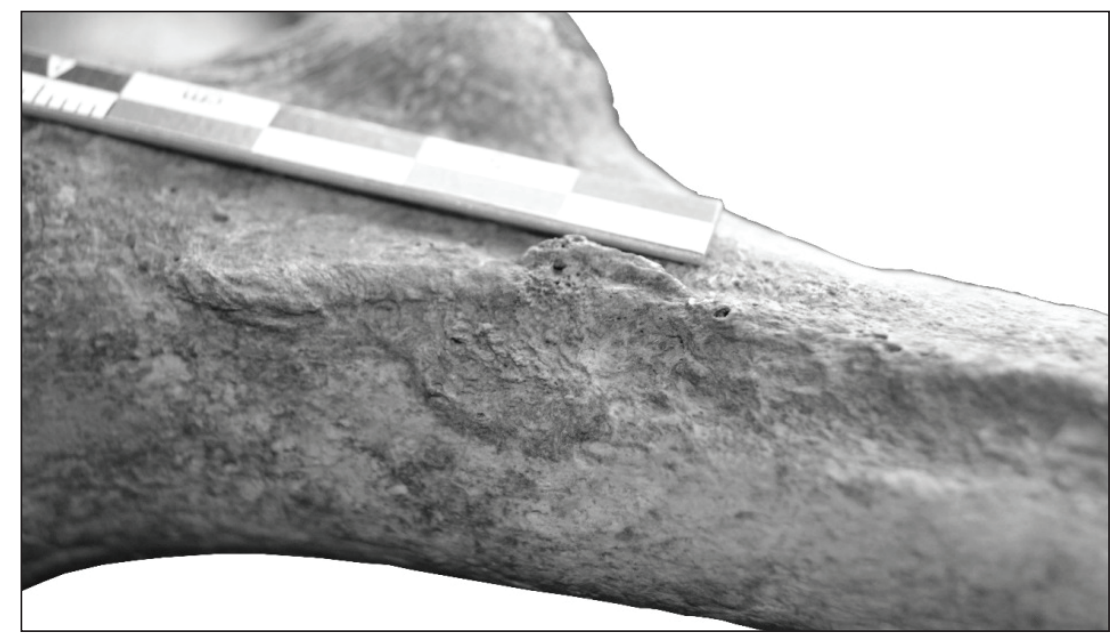

Fig. 28. Ejemplo de entesis de la cresta mayor del glúteo en la cara anterior del fémur izquierdo.

La antropometría solo se ha cuantificado en aquellos individuos que por motivos preservación ha sido posible realizar las diferentes mediciones sobre el hueso con un calibre digital, cinta métrica y tabla osteométrica. El cálculo de la estatura se ha estimado a partir de los métodos usuales ${ }^{88}$ y la lateralidad a partir de la diferencia existente entre el lado derecho e izquierdo. Esta última, aunque realizada, ha sido desestimada ya que no aportaba una información de importancia en el estudio que nos atañe a nivel poblacional, aunque sí ha sido posible inferir la lateralidad preferente de cada individuo. La antropometría, en otra vertiente, también se puede relacionar con las diferentes cargas biomecánicas a las que está sometida el hueso por parte del sistema muscular y que está sometida a las llamadas leyes de biomecánicas de Wollf o de Hueter-Volkman ${ }^{89}$. Ambas leyes son teóricas e ideales, siendo conscientes

cadores de estrés musculoesquelético en los huesos largos..."; Monsalve, Marcadores de actividad en la población del Cerro de La Encantada...; Niño, "Metodología para el registro de marcadores de estrés musculoesquelético"; Wilczac y Kennedy, "Mostly MOS: Aspects of Identification of Skeletal Markers", Kennedy, "Skeletal Markers of Occupational Stress".

${ }^{87}$ Lugar de unión entre un hueso y el sistema muscular propiciado por un tendón.

${ }^{88}$ TrotTer y Gleser, "Trends in stature of American whites and negroes born..."; Í "Re-evaluation of estimation of stature based on measurements of stature taken during life..."; $I_{D}$ "Corrigenda to "Estimation of stature from long limb bones of American whites and Negroes"”.

${ }^{89}$ SANTAMARÍA: Geometría de cortes transversales de una población arqueológica de Logroño... 
de que la lateralidad está sometida a procesos multifactoriales que pueden alterar la interpretación de resultados. En resumen, estas cargas biomecánicas y la diferencia de tamaño existentes entre huesos es otra de las variables tenidas en cuenta a la hora de valorar posteriormente los resultados de este estudio en cuánto al análisis de los marcadores de actividad de esta población.

La patología oral ha sido observada y analizada a partir de la nomenclatura de la $\mathrm{FDI}^{90}$ cuantificando la presencia y ausencia de las mismas. Entre las patologías y pseudopatologías cuantificadas están las caries, periodontolisis, abscesos dentales o bandas de hipoplasia dental entre otras. La hipoplasia dental también ha sido estudiada y analizada a través de métodos y técnicas propuestos en trabajos anteriores ${ }^{91}$. La base de su cuantificación se establece en su presencia o ausencia en la pieza dental siempre y cuando esta ha sido claramente observable a simple vista o con una lupa de pocos aumentos ayudados de luz natural o de un foco de luz artificial de escasa potencia (Fig. 29).

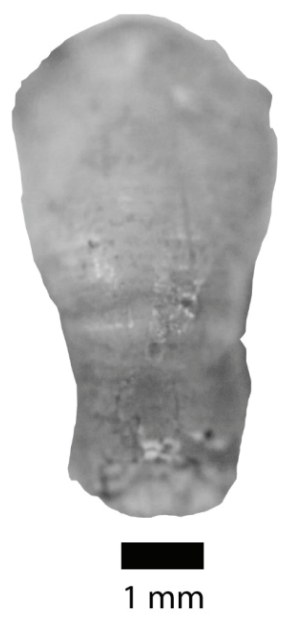

Fig. 29. Ejemplo de hipoplasia dental en un canino documentado en la necrópolis de Peñaflor (2013).

Las patologías asociadas a enfermedades articulares degenerativas han sido cuantificadas $^{92}$ con el objetivo de relacionarlas con los marcadores de actividad física siempre y cuando estas fueran claramente observables. Estas patologías, pueden estar provocadas por factores medioambientales, la edad del individuo, o algún tipo de patrón cultural accidental o incidental que pudiera haberlas provocado por lo que hay que ser cautos en su interpretación una vez obtenidos los resultados. Otras patologías que se han documentado han sido fracturas, infecciones y hernias discales entre otros que han sido puestos en relación con el contexto socio - cultural de esta población-.

\footnotetext{
90 Diagrama de Walter Drum o sistema de la F.D.I.

91 Trancho y Robledo, "Hipoplasia del esmalte dental: un indicador patológico".

${ }^{92}$ KRENZER, Traumas y paleopatología...
} 


\subsection{RESULTADOS}

La distribución por edad y sexo es propia de una población perteneciente al régimen demográfico preindustrial ${ }^{93}$. Este régimen está basado en picos de mortalidad en la infancia más temprana y un aumento en la edad adulta, siendo el grupo menos representativo el juvenil (Fig. 30). Las causas de este comportamiento pueden estar condicionadas por la salud infantil y el parto. La primera, debida a la mortalidad infantil (déficit nutricional, patologías con diferentes etiologías etc.) y la segunda con la muerte de madres en edad fértil durante o con casusas asociadas al parto. Todo ello, es una presunción debido al gran número de individuos adultos con edad o sexo indeterminado (debido a que no se cuenta con variables insuficientes para su estimación). A estos individuos, mencionados con anterioridad, solamente se les ha podido estimar una edad adulta por la fusión de los centros de osificación primaria o la erupción del tercer molar, pero no se ha logrado estimar con mayor precisión su edad debido (entre otros factores) a la escasa preservación del conjunto óseo ocurriendo lo mismo con los individuos no adultos. La falta de muestra, por tanto, impide realizar un análisis en mayor profundidad en cuanto a la edad y sexo de los individuos así como su distribución en el conjunto de la población estudiada. El número reducido de individuos perinatales esta motivado, posiblemente, a su escasa preservación incrementado por las condiciones tafonómicas a las que han sido sometidas hasta el momento de su excavación motivando así su falta de representación en la muestra ${ }^{94}$.

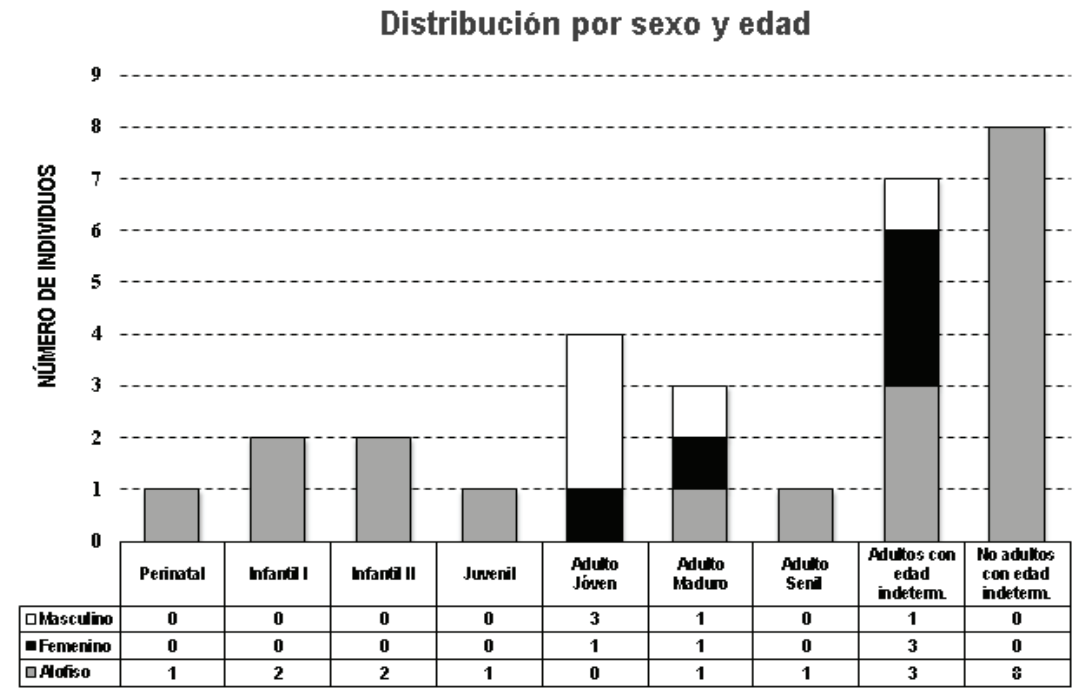

Fig. 30. Distribución de los individuos por edad y sexo de los individuos documentados en la necrópolis de Peñaflor (2013).

93 Entiéndase como un régimen demográfico carente de avances sanitarios y déficit nutricional en capas extensas de la población.

${ }^{94}$ GonzÁlez Martín ET AL., "La evolución de ‘los niños': algunas reflexiones sobre el registro fósil infantil”. 
La estimación de la estatura ha reflejado una estatura ligeramente superior (al menos de los individuos analizados) a otras colecciones de época medieval, tanto urbanas como rurales $^{95}$ (Fig. 31). Estos resultados son de gran importancia ya que la estatura está relacionada con la alimentación y ejercicio físico en la infancia y la adolescencia. La población perteneciente a la necrópolis de Peñaflor, por tanto, puede que tuviera una nutrición de mejor calidad, o al menos, más constante en el tiempo sin severas crisis nutricionales asociadas a estos individuos. Esta idea, sin embargo, debe de ser corroborada con el estudio de nuevos individuos de esta población que aumenten la muestra actual y dé unos resultados susceptibles de ser tratados estadísticamente. Si bien es cierto la estatura puede ser puesta en relación con otros marcadores de estrés nutricional -como las bandas de hipoplasia dental (Fig. 29, descritas más adelante) intentado inferir que, debido a la baja frecuencia de aparición de éstas, una estatura por encima de otras poblaciones contemporáneas-, quizás, esta población pudiera estar bien alimentada o que otros factores medioambientales o de índole genética propiciaran una estatura mayor que otras poblaciones estudiadas. Son hipótesis, que deben de ser corroboradas con una muestra mayor de individuos.

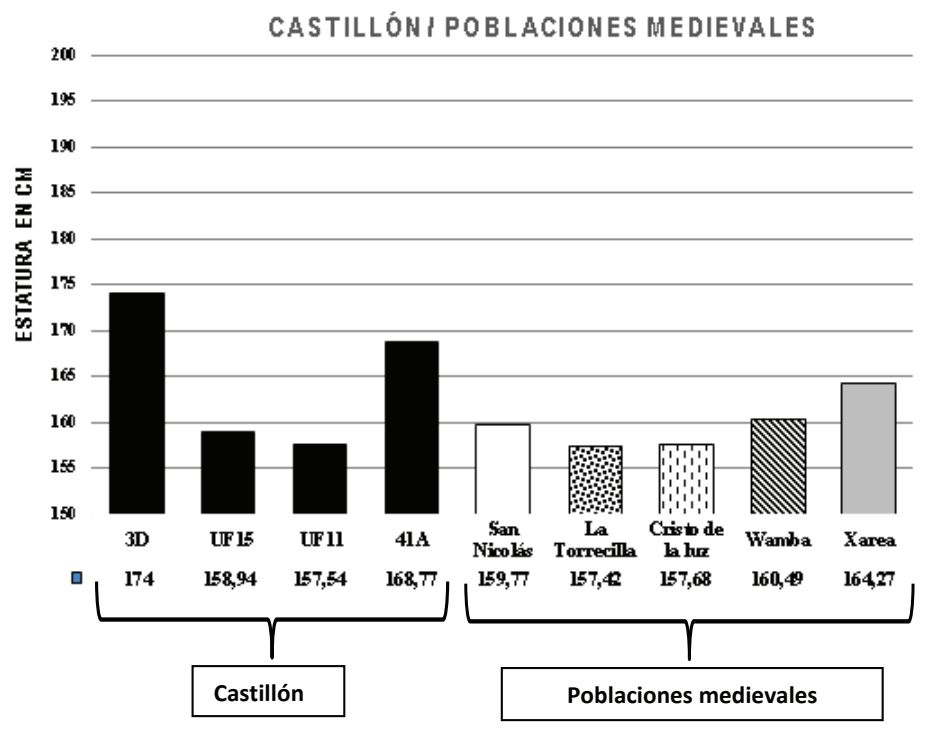

Fig. 31. Comparativa entre la estatura de los individuos estudiados en Peñaflor y otras poblaciones medievales conocidas.

Otra variable analizada de esta población son los marcadores de actividad muscular. Los individuos UF15, 11 y 41A (gozan de buena preservación), reflejan una fuerte demanda funcional en muchas de sus inserciones musculares. No se puede dilucidar una ocupación concreta, pero sí un esfuerzo importante a lo largo de su ciclo vital o cuánto menos en los últimos años de vida.

95 CRUZ ET AL, "Estudio de los marcadores de actividad de los restos recuperados de la Mezquita..."; LóPEZ-BuEIs, "Marcadores de estrés musculoesquelético en los huesos largos de una población..."; RoBLEDO, Dieta, indicadores de salud y caracterización biomorfológica de la población medieval...; 
Los marcadores se concentran principalmente en las extremidades superiores. En el húmero las mayores frecuencias se concentran en las inserciones de los tendones asociados a músculos como el pronador, supinador, extensor radial del carpo, braquiorradial, flexor radial del carpo, palmar largo, flexor cubital del carpo y flexor cubital de los dedos. El radio, también ha presentado marcas de actividad física siendo la más destacable aquella asociada al músculos bíceps radial. En el caso del cúbito, la escasa preservación de la muestra ha impedido un análisis en mayor profundidad. Estos marcadores de actividad muscular fueron puestos en relación en trabajos anteriores con la producción textil, descardado ${ }^{96}$ o lanzamiento de objetos ${ }^{97}$.

Las extremidades inferiores revelan exostosis y excreencias en la tuberosidad glútea del fémur puestos en relación con movimientos como subir escaleras o sentarse en el suelo $^{98}$ y en la entesis del tendón de aquiles del calcáneo. Ambos marcadores, están relacionados con largas caminatas, subir y bajar por accidentes escarpados e incluso a una posible obesidad que habría que analizar a nivel individual ${ }^{99}$.

Dejando momentáneamente de lado a los individuos adultos, se han podido constatar otras marcas de actividad ligadas a individuos juveniles. El individuo UF21A presenta en su húmero derecho una exostosis de considerable tamaño en la inserción tendinosa del pectoral mayor en la cresta del tubérculo mayor (pectoralis major) (Fig. 32). Estudios sobre análisis de marcadores de actividad en poblaciones del pasado de cronología medieval inciden en relacionar a dicho músculo con actividades como la trilla, la siembra, recolección, carga de pesos ${ }^{100}$ y la oposición de una fuerza a dicho músculo ${ }^{101}$.

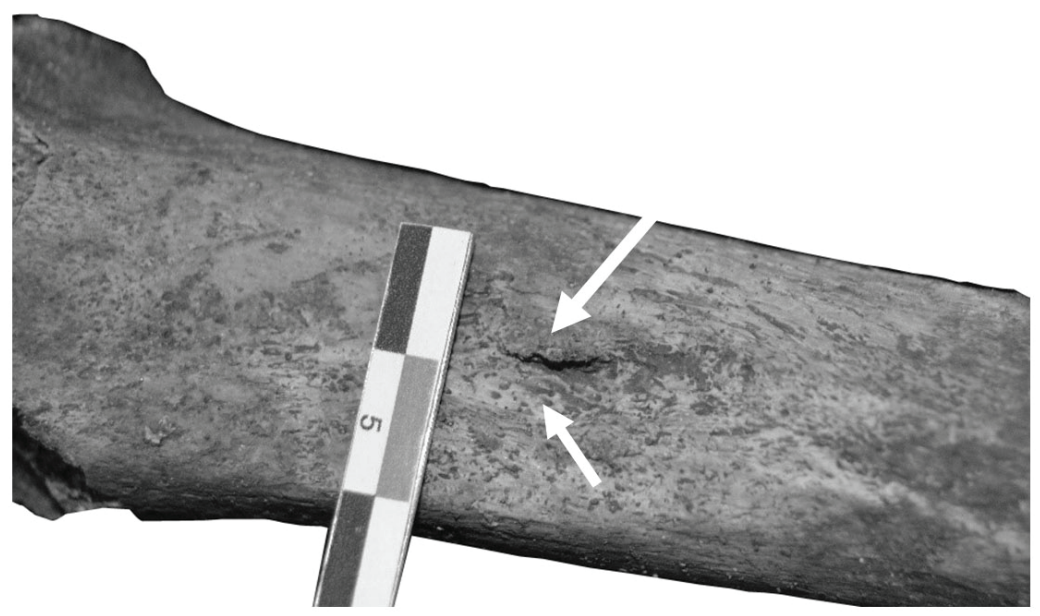

Fig. 32. Inserción del pectoral mayor en un húmero juvenil de la población estudiada.

\footnotetext{
96 Robledo, Dieta, indicadores de salud y caracterización biomorfológica de la población medieval...

97 CAPAsso et AL., Atlas of Occupational Markers on human remains.

98 Robledo, Dieta, indicadores de salud y caracterización biomorfológica de la población medieval...; CAPASSO ET AL., Atlas of Occupational Markers on human remains.

99 IBIDEM.

${ }^{100}$ López-BuEIs, "Marcadores de estrés musculoesquelético en los huesos largos de una población...".

101 Capasso et AL., Atlas of Occupational Markers on human remains.
} 
La enfermedades articulares degenerativas son reconocibles en forma de fenómenos artriricos u osteoartriticos en las articulaciones del cuerpo humano. Esta población ha reflejado altos niveles de presencia de dichas patologías (más de un $25 \%$ ) en sus áreas articulares pudiendo estar asociadas a diferentes etiologías como el envejecimiento, traumatismos, sobrecargas mecánicas o luxaciones ${ }^{102}$ (Fig. 33).

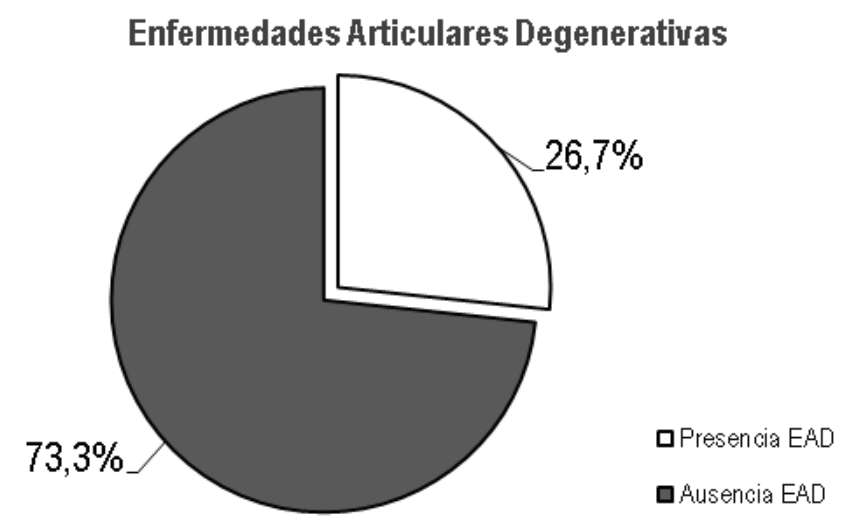

Fig. 33. Presencia de Enfermedades Articulares Degenerativas en la población adulta de la necrópolis del Castillón

El análisis de la hipoplasia dental refleja resultados diversos en los individuos en los que ha sido posible determinar fehacientemente este tipo de procesos (Figs. 29 y 34). La edad de formación de estos procesos hipoplásicos oscila entre los 1 y los 3,6 años de edad. Estos fenómenos pueden estar ligados a deficiencias nutricionales, malas condiciones sanitarias, infecciones o el destete en edad infanti ${ }^{103}$. La presencia de sarro también ha sido documentada en algunos individuos de la población de Peñaflor siendo ésta más frecuente en los individuos adultos que en los no adultos.

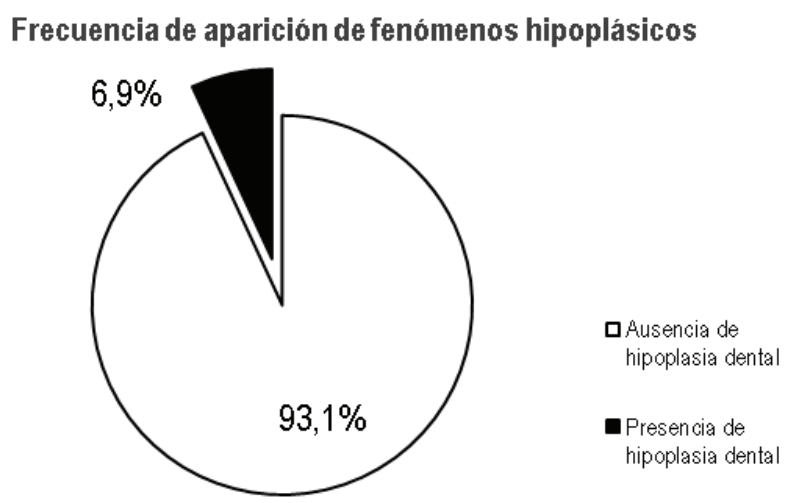

Fig. 34. Prevalencia de la hipoplasia dental en la población de la necrópolis del Castillón.

102 Estévez, Marcadores de estrés y actividad en la población guanche de Tenerife.

103 Trancho y Robledo, "Hipoplasia del esmalte dental: un indicador patológico". 
Las patologías documentadas aportan una información muy interesante (Fig. 35). Las enfermedades articulares degenerativas son las mas frecuentes seguidas de otras, como las caries, fracturas e infecciones.

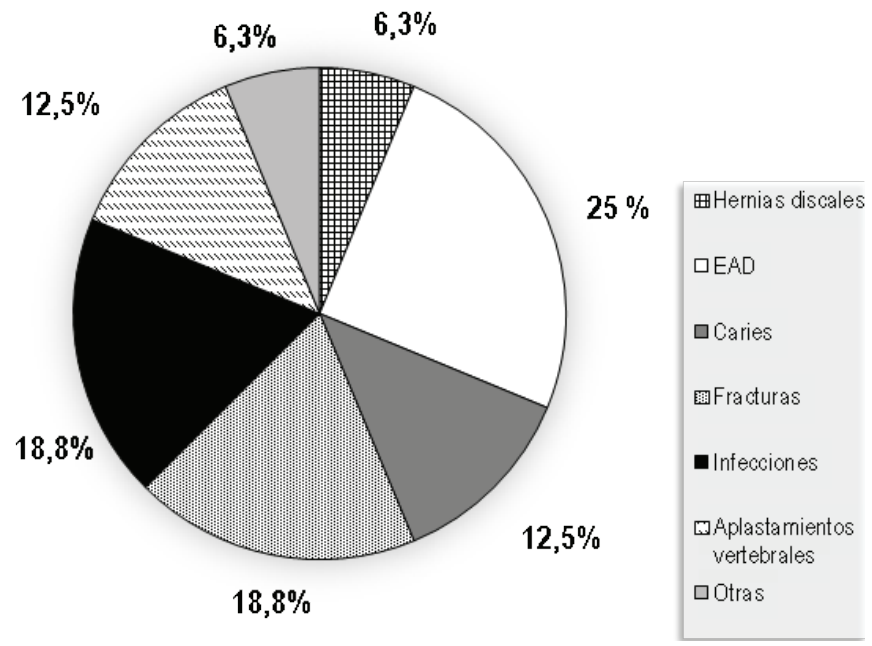

Fig. 35. Patologías detectadas en la población de Peñaflor por porcentaje.

Se han podido registrar y observar otras anomalías de carácter paleopatológico en esta población. Una de las más características es la documentación de un posible impacto de proyectil en una de las vértebras lumbares estudiadas. La herida, mortal de necesidad sin un tratamiento adecuado -no se han encontrado signos de remodelación ósea-y de carácter inciso-punzante, penetró por el plano subcostal izquierdo del individuo (Fig. 36). Esta, probablemente, causó daños en órganos internos como el intestino delgado y quizás en la vena cava inferior y en la aorta abdominal impactando directamente contra la tercera vértebra lumbar y el ligamento interarticular en su cara superior.

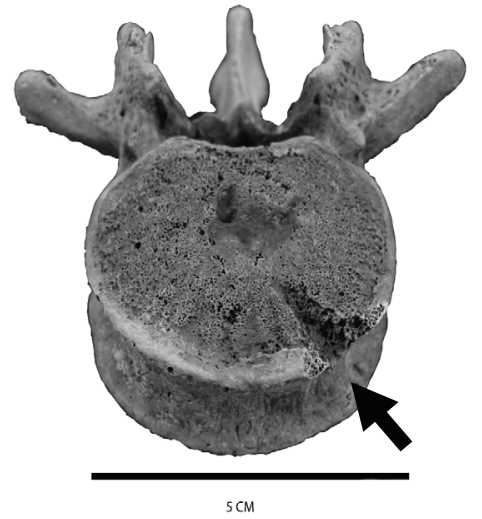

Fig. 36. Herida, probablemente mortal, de carácter inciso-punzante documentada en una vértebra, tercera lumbar (cuadro F2, descontextualizada). 
No solamente se han encontrado estos signos que pudieran, quizás, estar asociados a episodios de violencia interpersonal. Tanto en los informes antropológicos de $2005^{104}$, como en este trabajo de 2013, se documentaron otras fracturas que pueden tener una causa basada en la violencia entre individuos. Entre ellas una fractura en un malar y clavícula derecha, ambas con signos de regeneración y osificación en forma de callo óseo -en el caso de la clavícula- (Fig. 37).

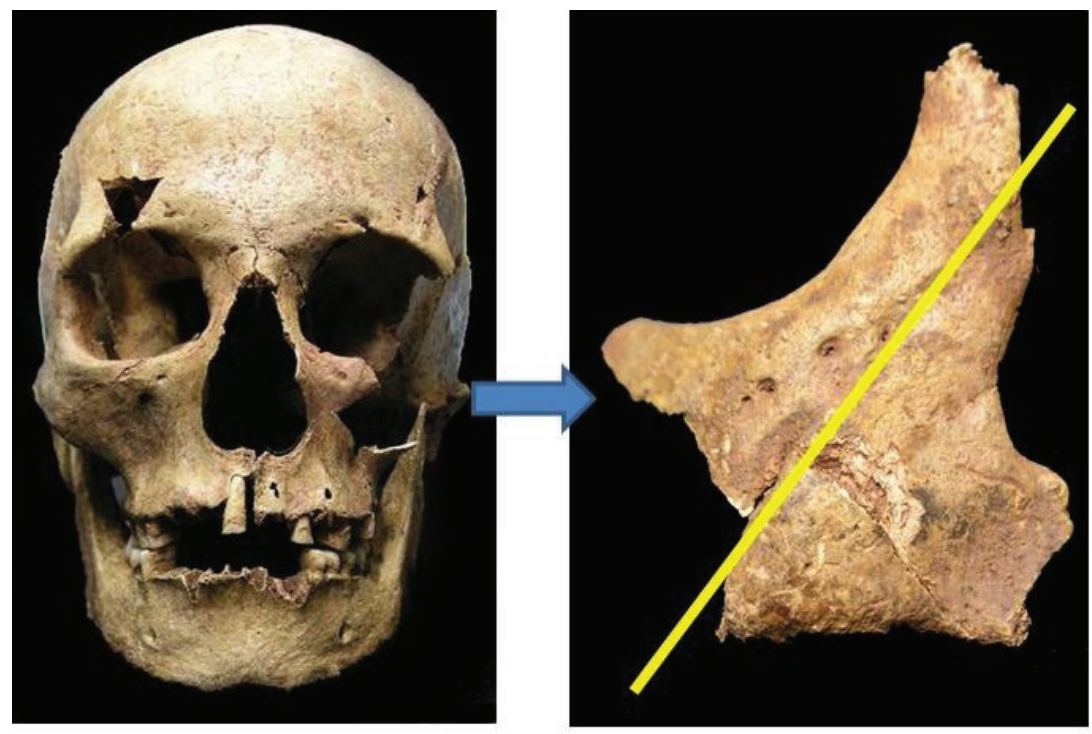

CEF1-UF7

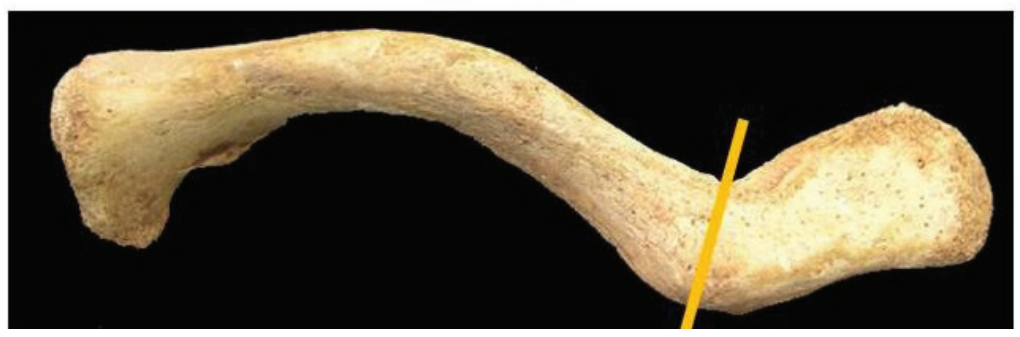

Fig. 37. Fractura en un malar y en clavícula derecha del individuo UF7, ambas con signos de regeneración y osificación.

\section{CONCLUSIONES}

El asentamiento de Peñaflor posibilita profundizar en las características territoriales, urbanas y humanas de los pobladores de una pequeña aldea de Repoblación pero que hallaba su razón de ser en una estrategia de ataque, ocupación y defensa cristiana para la liquidación de la conquista de La Meseta. Y es que, como estamos empezando a

104 RASCÓn ET AL., Estudio antropológico de los restos... 
comprender aquí y en otras áreas ${ }^{105}$, hablar de estrategia militar y defensas para un poblamiento medieval no siempre implica la existencia de sólidas y enormes murallas de un encumbrado y legendario castillo.

Vinculamos desde el principio este poblamiento medieval a la órbita cristiana y no con la islámica porque así parece mostrarlo los elementos de juicio de los que disponemos. Ni estamos ante una arquitectura militar típica almohade ${ }^{106}$, ni la necrópolis se basa en el rito coránico. Aún así, tampoco debería extrañar la presencia de algún material de tradición andalusí, pues su existencia debe entenderse totalmente normal dentro de los contactos de un contexto de frontera dinámica.

El marco cronológico más factible y razonable a día de hoy es datar la fundación de Peñaflor a raíz de la expedición alfonsí (1213) o incluso en torno a la caída de Montiel (1227). Sin embargo, no deja de ser interesante explorar otras posibilidades partiendo también de fuentes históricas y arqueológicas. Ante una incierta autoría y fecha de reconquista y colonización cristiana de esta parte de la Meseta Sur, el caso de Peñaflor podría incluso sugerir reformular la Historia política y humana de la zona.

El avance cristiano a la línea del río Guadiana durante el siglo XII se materializará por el empuje real y el avance de los caballeros calatravos - por el Oeste de la actual provincia- y por el de los santiaguistas desde Uclés, tal y como muestra la confirmación de distintos territorios en la bula de Alejandro III de $1175^{107}$. Pero cualquier análisis de la conquista y repoblación del territorio para esta época no deber perder de vista la enorme permeabilidad de las supuestas fronteras políticas y geográficas entre los mundos cristiano de la llanura manchega y el islámico del Campo de Montiel, Sierra Morena-Segura y el Alto Guadalquivir. Una rápida ojeada a las razzias y maniobras del siglo XII no deja lugar a dudas del constante paso de contingentes $-\mathrm{y}$, por lo tanto, también comercio y todo tipo de movimientos- en unas sierras que, aunque respetables, estaban surcadas de pasos y rutas de larga distancia ${ }^{108}$. Por ejemplo, sólo así se entiende en el siglo XII una empresa contra Almería (1147-1157) y otras batallas en la vertiente Sur de Sierra Morena (1169) ${ }^{109}$, o que en 1434 una expedición musulmana de la Sierra de Huéscar -Granada- volviera a penetrar en el Campo de Montiel hasta asediar el torreón de Terrinches ${ }^{110}$.

105 Vigil-Escalera, "El modelo de poblamiento rural en La Meseta..."; ID y TeJerizo, "Asentamientos fortificados altomedievales en la Meseta..."; Ferreira, Mil Anos de Fortificaçoes Na Península Ibérica...; ÍD., Castelos das ordens militares.

106 Márquez y Gurriaran, "Recursos formales y constructivos de la arquitectura militar almohade en al-Andalus".

107 Inter alia, RuIz, Los orígenes de las órdenes militares y la repoblación...; MATELLANEs, "La colonización Santiaguista del Campo de Montiel”. La conquista, repoblación y reorgnización seguiría inexorablemente: Rodríguez Molina, "Las Ordenes Militares de Calatrava y Santiago en el Alto Guadalquivir..."; Porras ArboledAs, "La repoblación de La Mancha santiaguista...”; AyAlA, "Las Órdenes Militares y la ocupación del territorio manchego...".

108 Corchado, "Pasos naturales y antiguos caminos entre Jaén...”; Íd "Estudio sobre vías romanas entre el Tajo y el Guadalquivir”. SÁnchez SÁnchez, “Caminos históricos Toledo-Córdoba...”; Moya-Maleno, “¿Caminante, no hay camino...? Territorio y economía de la Edad del Bronce...”, p. 646.

109 SÁnchez SÁnchez, "Los caminos de la batalla: las Navas de Tolosa, 1212", passim.

110 Corchado, Avance de un estudio geográfico-histórico..., pp. 164s; Benítez de Lugo ET AL., "La frontera occidental del concejo de Alcaraz en la Edad Media..."; GARcíA Fitz, "Una frontera caliente: la guerra en las fronteras castellanomusulmanas...". 
En este contexto, las incursiones cristianas a los dominios musulmanes bien pudieron dar como resultado en esta parte de la comarca montieleña una primera ocupación de plazas, cuestión ésta ya albergada por A. Blázquez y M. Corchado ${ }^{111}$, por ejemplo, para los casos de Almedina (1142) o Eznavejor (1182). Estos planteamientos han sido recientemente defendidos por Á. Madrid ${ }^{112}$, no sólo también sobre lo señalado por el cronista F. de Rades y otros historiadores y archiveros de la propia Orden, sino apoyándose en la documentación contemporánea a los hechos. Así es como, a tenor de lo expuesto por la investigadora, queda patente en distintos testimonios la gran actividad militar de la Orden de Santiago en el Campo de Montiel en el último tercio del siglo XII: en 1177 quedaba asegurado y libre parte del Priorato de Montiel ${ }^{113} \mathrm{y}$, entre 1184 y 1186, el Maestre Fernando Díaz también realizó rápidas conquistas en la zona por ser territorio vecino a Uclés ${ }^{114}$. También A. Pretel ha expuesto el protagonismo que adquirió en un primer momento el concejo de Alcaraz en la altiplanicie $e^{115}$.

Bien parece que tal hostigamiento quedó frenado en seco tras la derrota de Alarcos en 1195 y que durante la siguiente tregua -de más de una década- hubo un restablecimiento aparente de la frontera en el río Tajo ${ }^{116}$. Sin embargo, a ciencia cierta, se trata de una época oscura para conocer lo verdaderamente acontecido en este territorio hasta la cabalgada de Alfonso VIII, al igual que para conocer la realidad y evolución de estas conquistas y del destino de otras posibles fundaciones cristianas entre este hecho y la caída de Montiel (1227).

Sea como fuere, este asentamiento también nos permite atisbar una dinámica de guerra lejana de tropas frente a frente y de grandes batallas. Aunque pudiera haber un contingente militar, lo que observamos es una población completa, con individuos de ambos sexos y de todas las edades. La estrategia en un momento de tensión media o baja parece ampararse en la mínima protección que daba el emplazamiento más que confiar en una arquitectura militar inexpugnable: una frontera caliente ${ }^{117}$. Dicho de otro modo, todo parece indicar una ocupación estratégica del territorio y una guerra psicológica a las plazas musulmanas del entorno bien en un tiempo de tregua, bien en un contexto bélico más desordenado de lo que habitualmente se estima ${ }^{118}$. Tal planteamiento encaja con el panorama que dibujan las fuentes durante las dos décadas

\footnotetext{
111 IBÍD pp. 49 y 78.

112 MADRID, "La Orden de Santiago hasta la conquista de Alcaraz”, pp. 234-239. Íd "Los orígenes de la presencia de la Orden de Santiago...".

113 AHN, Códices L. 337, sin foliar, año 1185. Pub. MAdrID, "Los orígenes de la presencia de la Orden de Santiago...”.

114 Chaves, Apuntamiento Legal sobre el dominio solar..., p. 16 v. MADRID, "Los orígenes de la presencia de la Orden de Santiago...".

115 Pretel, "Conflictos de interés en el repartimiento y la repoblación..."; ÍD Alcaraz y su tierra en el siglo XIII; ÍD Alcaraz: del Islam al concejo castellano.

116 Alvira Cabrer, "De Alarcos a las Navas de Tolosa...”, pp. 252-253; Matellanes, "La Orden de Santiago y la organización social de la Transierra...”, p. 118; MolERo y GALLEGo, "El primer encastillamiento cristiano en el Campo de Montiel (1213-c.1250)".

117 García Fitz, "Una frontera caliente: la guerra en las fronteras castellanomusulmanas...".

118 Son altamente sugestivos para este momento medieval los estudios realizados al respecto de la guerra psicológica en otras épocas históricas y anteriores, por ejemplo, en el caso de la funcionalidad y visibilidad de las murallas: PArcero, "Tres para dos. Las formas...”; Fernández OchoA y Morillo, "Entre el prestigio y la defensa:..."; Berrocal, "La defensa de la comunidad: sobre las funciones...".
} 
entre la batalla de Alarcos (1195) y la cabalgada alfonsí (1213), aunque la norma ha sido contemplar este periodo como escenario de razzias de ambos contendientes y no como una colonización formal o de asedios intermitentes ${ }^{119}$.

La inexistencia de grandes alturas en las que encastillarse hizo buscar en un espolón y en la propia verticalidad de las laderas un lugar en el que fortificar una aldea que fuera capaz de aguantar acometidas de rezias o pequeños contingentes. Pero también para poder controlar y quizás fiscalizar el paso de cuantos viajeros y contingentes pasaran por estas rutas de primer orden entre los reinos cristianos y musulmanes. Y todo ello sin dejar de lado la posibilidad de subsistir con los recursos que aportara el entorno más inmediato. Son estos aspectos económicos, de organización local, conflictividad social, religiosidad, etc., los que, sin fuentes archivísticas más concretas ni nuevos datos arqueológicos, serán más difíciles de reconstruir ${ }^{120}$.

En cuanto a las características antropológicas y patologías de la población de la necrópolis de Peñaflor ahora estudiada, las patologías observadas son las frecuentes en este tipo de sociedades: demanda funcional muy acusada, higiene bucodental insuficiente $-\mathrm{y}$ posiblemente de su entorno-, patologías en articulaciones, fracturas etc. A pesar de la reducida muestra, las patologías halladas sumadas al contexto y circunstancias históricas, sugieren que algunas patologías asociadas a estos individuos pudieran estar provocadas por enfrentamientos con otros individuos. Para corroborar dicha hipótesis habría que contar con una muestra mucho más amplia, con más ejemplos que verifiquen esta idea de partida tal y como ocurre con otras anomalías antropológicas.

En otra vertiente, los datos reunidos parecen mostrar, a priori, una comunidad bien alimentada -base de la buena salud de una población- aunque las duras condiciones de vida mermarían su esperanza de vida. Así lo sugieren las patologías articulares detectadas y su razonable vinculación a un duro esfuerzo físico desde épocas tempranas de su ciclo vital.

Los datos de los que disponemos son todavía limitados por lo que tanto para los aspectos urbanísticos como antropológicos, estos deberán de ser contrastados con el aumento de estructuras, materiales e individuos procedentes de Peñaflor. Nuevas intervenciones confirmarán esta tendencia o bien podrán cambiar nuestra perspectiva.

Con estos datos y premisas de Peñaflor podríamos entrar de lleno en la controvertida atribución de la procedencia y tipo de ocupación y colonización del Campo de Montiel, bien por parte del concejo de Alcaraz, bien por la Orden de Santiago, desarrollada por autores como los mencionados A. Pretel y Á. Madrid. Aunque carecemos de elementos arqueológicos para decantarnos por una u otra opción, y a expensas de próximos estudios, lo que parece claro es que su localización y el matiz bélico de la plaza auspicia su inclusión en la órbita santiaguista. La ubicación de un punto

119 Contra Matellanes, "La Orden de Santiago y la organización social de la Transierra...”, p. 118. Al fin y al cabo se trataba de la necesidad de estructurar una red de control del territorio: GonZÁLEZ GonZÁLEZ, Repoblación en Castilla La Nueva, p. 34; AyAla, Las órdenes militares hispánicas en la Edad Media, p. 42.

${ }^{120}$ De ahí la importancia de contar con síntesis más o menos generales, construidas sobre documentación dispersa, que permitan aportar un contexto mínimo a este tipo de pequeños asentamientos. Véase, inter alia, GARCíA DE CORTÁZAR, "La organización social del espacio en La Mancha medieval..."; ÍD. ET AL., Organización social del espacio en la España medieval..., p. 154s; Matellanes, "La Orden de Santiago y la organización social de la Transierra..."; Rodríguez-PicaveA, "La ganadería en la economía de frontera...". 
neurálgico musulmán fortificado como Montiel entre Peñaflor y su supuesta cabecera -Alcaraz-y el emplazamiento de nuestra aldea en rutas al Norte y al Oeste, favorecen a priori esta interpretación.

La continuidad de varias generaciones inhumadas, como también se aprecia en la práctica de las reducciones, es el mejor indicador de la vitalidad del asentamiento de Peñaflor, cuando menos, durante varias décadas y generaciones. Quizás muchas más de las que los textos político-administrativos medievales pretendían mostrar con supuestos "despoblados" y que fueron asumidos como ciertos por los autores posteriores con demasiada ligereza ${ }^{121}$.

A este respecto, cabe esperar que los futuros estudios del uso y pervivencia del cementerio y aldea de Peñaflor sirvan de referencia para el conocimiento de otros modelos de poblamiento medievales ex novo del Campo de Montiel así como el papel desempeñado por sus gentes en la fundación, desarrollo y/o continuidad de los mismos. Especialmente interesante será dilucidar los procesos de abandono y el nuevo empuje de otros centros cercanos ${ }^{122}$, en nuestro caso, el de La Moraleja-Villanueva de los Infantes. El desmantelamiento de Peñaflor como aldea estará reflejado en el declive de su camposanto, aunque no por ello hemos de pensar en un olvido y en un desapego inmediato hacia esos antepasados del Castillón, más aún cuando Peñaflor, de una forma u otra, siguió siendo un referente en el territorio.

\section{Agradecimientos}

Agradecemos a cuantas personas e instituciones han hecho posible este estudio y proyecto, ya sea en el capítulo de soporte económico y material (M.I. Ayuntamiento de Villanueva de los Infantes, Fundación José $\mathrm{M}^{\mathrm{a}}$ de Jaime, Caja Rural Castilla-La Mancha, Bar El Candil I y Emilio García), como en la ejecución de la excavación y posteriores análisis en laboratorio. Especialmente es de agradecer la colaboración de los profesores Miguel Á. Mancheño, Armando González y Josefina Rascón; y, por supuesto, a los colaboradores de campo y de laboratorio de 2004 y 2013: Abel Ruiz, Andrea Alonso, Beatríz Tante, Carlos Campayo, Carmen Palao, Christian Azibal, Cristina Jiménez, Daniel Hernández, David Vacas, Diego Lushinger, Elena Cáceres, Elina Rodríguez, Elvira Fabregat, Jesús Bermejo, Jose A. Cano, Juan Cruz, Lorena Marín, Luis M. Carrillo, Manuel García, Marta Estalayo, Nieves Sánchez, Pablo Guerra, Rocío Losa, Tomás García y Víctor García.

${ }^{121}$ Fue paradigmática a este respecto la obra de SÁNCHEZ-AlboRnoz, Despoblación y repoblación del Valle del Duero. El concepto se ha revisado posteriormente tanto desde el punto de vista documental, como arqueológico, inter alia: Molénat, "Les diverses notions de 'Frontière' dans la region de Castilla-La Mancha..."; Martín Viso, Poblamiento y estructuras sociales en el norte...; Pretel, “¿Pervivencias cristianas bajo dominio islámico en las sierras de Alcaraz y Segura?".

${ }^{122}$ GonzÁlez GonzÁlez, Repoblación en Castilla La Nueva, p. 252. 


\section{FUENTES Y BIBLIOGRAFÍA}

Bullarium equestris ordinis S. Iacobi de Spatha per annorum seriem nonnullis Donationum - alijs interiectis Scripturis, ed. de A.F. Aguado de Córdova, A.A. Alemán y J.L. de Agurleta. Madrid: Tip. de Juan de Aritzia, 1719.

MANCheÑo JimÉnez, Miguel Ángel (2004): "Informe sobre posibles riesgos de deterioro por procesos geológicos que pueden afectar a la necrópolis del cerro del Castillón de Villanueva de los Infantes”, en Juan José Espadas y Pedro Reyes Moya Maleno (dirs.): Memoria de la intervención de urgencia en el "cerro del Castellón" (Villanueva de los Infantes, Ciudad Real). 3-15 de julio de 2004, Junta de Comunidades de Castilla-La Mancha, Inédito, pp. 67-71.

Rascón, Josefina, Pimentel, Guillermo, Alonso, Andrea, CAmpo, Manuel y GonzáLEz MarTín, Armando, Estudio antropológico de los restos óseos del yacimiento "El Castellón". Villanueva de los Infantes (Ciudad Real). Madrid: Laboratorio de Poblaciones del Pasado (UAM). Informe técnico inédito para el Proyecto Arqueológico 'Entorno Jamila'. 12 pp.

ACSAÁDI, Giörgy y Nemeskéri, János, History of human life span and mortality. Budapest: Akadémiai Kiadó, 1970.

Al Oumaou, Ihab, Jiménez Brobeil, Silvia Alejandra y Du Souich, Philippe, "Markers of activity patterns in some populations of the Iberian Peninsula", International Journal of Osteoarcheology. 14 (5) (2004), pp. 343-359.

Altimiris, Els, "La cisterna 1 de Els Altimiris (Marc)", en Els Altimiris. Entre l'Antiguitat Tardana $i$ l'Alta Edat Mitjana: https: //altimiris.files.wordpress. com/2012/07/esquema-cisterna.jpg, 2012 (acceso 10-X-2014).

Alvira CABrer, Martín: "De Alarcos a las Navas de Tolosa: idea y realidad de los orígenes de la batalla de 1212", en Ricardo Izquierdo y Francisco Ruiz (coord.): Alarcos, 1195: Actas del Congreso Internacional Conmemorativo del VII Centenario de la Batalla de Alarcos, Ciudad Real, 1996, pp. 249-264.

Aurell i Cardona, Jaume y Pavón, Julia, (eds.), Ante la muerte, actitudes, espacios y formas en la España Medieval, Pamplona: EUNSA, 2002.

Ayala Martínez, Carlos de, "Las Órdenes Militares y la ocupación del territorio manchego (siglos XII-XIII)", en Alarcos, 1195: Actas del Congreso Internacional Conmemorativo del VII Centenario de la Batalla de Alarcos, R. Izquierdo y F. Ruiz (coord.), Ciudad Real, 1996, pp. 49-104.

Ayala Martínez, Carlos de, Las órdenes militares hispánicas en la Edad Media (siglos XII-XV), Barcelona: Marcial Pons Historia, 2007.

Benítez de Lugo Enrich, Luis y Álvarez García, Honorio Javier, "Mentesa Oretana 2001-2002. Excavaciones arqueológicas en los solares c/ Callejón del Aire, n. ${ }^{\circ}$ 7 y c/ Ciudad Mentesa n. ${ }^{\circ} 14$ y 22 (Villanueva de la Fuente, Ciudad Real)", en 
Luis Benítez de Lugo (dir.): Mentesa Oretana. 1998-2002. Valdepeñas: Anthropos, 2003, pp. 275-290.

BeníteZ de Lugo EnRich, Luis, "Protección y gestión de la Arqueología en CastillaLa Mancha: el caso del Campo de Montiel (Ciudad Real). Inercias y resistencias", Revista de Estudios del Campo de Montiel, 2 (2011), pp. 13-56.

Benítez de Lugo, Luis, Álvarez, Honorio Javier, Mata, Enrique, Torres, Miguel, Moraleda, Jaime e Cabrera, Isabel, "Investigaciones arqueológicas en Mentesa Oretana (Villanueva de la Fuente, Ciudad Real) 2003-2009: muralla ibérica, área urbana y necrópolis tardoantigua e islámica”, Espacio, tiempo y forma. Serie I, Prehistoria y arqueología, 4 (2011), pp. 309-336.

Benítez de Lugo, Luis, Álvarez, Honorio Javier, Torres, Miguel, Moraleda, Jaime y Mata, Enrique, "La frontera occidental del concejo de Alcaraz en la Edad Media. Estudios arqueológicos del castillo de Terrinches, el castillo de los Baños del Cristo y la alcazaba de Villanueva de la Fuente (Ciudad Real)", en A. Pretel Marín (coord.), Alcaraz: del Islam al concejo castellano, Albacete, 2013, pp. 243-274.

Berrocal Rangel, Luis, "La defensa de la comunidad: sobre las funciones emblemáticas de las murallas protohistóricas en la Península Ibérica", Gladius, 24, pp. 27-98.

Buikstra, Jane E., Ubelaker, Douglas, "Standards for data collection from human skeletal remains", Arkansas Archeological Survey Research Series. 44 (1994), pp. 106-123.

BuRns, Karen Ramey, Forensic anthropology training manual, New Jersey: Prentice Hall, 1999.

Campayo, Carlos, Moya-Maleno, Pedro R. y Bastos, Ángel David, “Territorio y comunicaciones medievales en el Alto Valle del Jabalón durante el siglo XIII: experimentalidad y propuestas", en P.R. Moya-Maleno (ed.): Campo de Montiel 1213: Entre el Islam y el Cristianismo. RECM Extra 1. Villanueva de los Infantes, en prensa.

Campos Fernández de Sevilla, Francisco Javier, "La descripción del Partido, Suelo y Campo de Montiel para el Mapa y las Relaciones Geográficas de D. Tomás López", Revista de Estudios del Campo de Montiel, 3 (2013), pp. 171-199.

Capasso, Luigli, Kennedy, Karl A. R. y WilczaK, Cynthia A., Atlas of Occupational Markers on human remains, Teramo: Edigrafital S.P.A, 1999.

Chaves, Bernardo de , Apuntamiento Legal sobre el dominio solar de la Orden de Santiago en todos sus pueblos, Barcelona: Reimp. Ed. El Albir, 1975 [1750].

Colón, Hernando, Descripción y Cosmografia de España, Tomo II, Sevilla: Padilla Libros, 1988 [1517].

Corchado Soriano, Manuel, "Pasos naturales y antiguos caminos entre Jaén y La Mancha”, Boletín del Instituto de Estudios Giennenses, 38 (1963), pp. 9-37.

Corchado Soriano, Manuel, Iniciación al estudio geográfico-histórico del priorato de Uclés en La Mancha, Ciudad Real: Instituto de Estudios Manchegos, 1965. 
Corchado Soriano, Manuel, "Estudio sobre vías romanas entre el Tajo y el Guadalquivir", Archivo Español de Arqueología, 42 (1969), pp. 124-158.

Corchado Soriano, Manuel, Avance de un estudio geográfico-histórico del Campo de Montiel. Ciudad Real: Instituto de Estudios Manchegos, 1971.

Coriolano, Maria das Graças Wanderley de Sales, Lins, Otávio G., Amorim, Mario Joao Rodrigues y Amorim, Jr. Adelmar Afonso de, "Anatomy and Functional Architecture of the Anconeus Muscle", International Journal of Morphology, 27 (4) (2009), pp. 1009-1012.

Cressier, Patrice y Salvatierra, Vicente, Las Navas de Tolosa, 1212-2013. Jaén: Miradas Cruzadas y Universidad de Jaén, 2014.

Cruz, Laura de la, Gutiérrez de Calderón, Luz y San Miillán, Marta, "Estudio de los marcadores de actividad de los restos recuperados de la Mezquita del Cristo de la Luz (Toledo)", en X Congreso Nacional de Paleopatología, Madrid, 2011, pp. 463-469.

Delgado Valero, Clara, Materiales para el estudio morfológico y ornamental del arte Islámico en Toledo. Toledo: JCCM-Museo de Santa Cruz, 1987.

Dutour, Olivier, "Entesopathies (lesions of muscular insertions) as indicators of the activities of Neolithic Saharan population", American journal of Physical Anthropology, 71 (1986), pp. 221-224.

Escudero Buendía, Francisco Javier, La Iglesia de Santa Catalina de La Solana (s. $X I I-X V)$. Orígenes de la villa. Diputación de Ciudad Real y Fundación Paulino Sánchez Delgado. Tomelloso: Ed. Soubert, 2003.

Espadas Pavón, Juan José, "El yacimiento arqueológico de Jamila (Villanueva de los Infantes)", en Luis Benítez de Lugo (coord.): El Patrimonio arqueológico de Ciudad Real: métodos de trabajo y actuaciones recientes, Valdepeñas, 2000, pp. 323-354.

Espadas Pavón, Juan José y Moya-Maleno, Pedro R., “Un 'Puente Romano’ sobre el río Jabalón (Villanueva de los Infantes, Ciudad Real, España): el Campo de Montiel como zona de paso desde la Antigüedad", en Joâo Bernardes (ed.): Hispania Romana: Actas do IV Congresso de Arqueologia Peninsular, Faro, 2008, pp. 283297.

Espadas Pavón, Juan José y Moya-Maleno, Pedro R., "Cuando la tierra se abre. Intervención de urgencia en una necrópolis de 'El Castillón' (Villanueva de los Infantes, C. Real)", en M. Zarzalejos et al. (eds.): I Congreso de Patrimonio Histórico de Castilla-La Mancha. La Gestión del Patrimonio Histórico Regional, Ciudad Real, 2007, pp. 379-388.

Espadas Pavón, Juan José, "Prospecciones en el Campo de Montiel II. El Cerro de los Conejos (Villanueva de los Infantes, Ciudad Real), nuevo yacimiento calcolíticoBronce". Cuadernos de Estudios Manchegos, 15 (1984), pp. 11-37.

Espadas, Juan José, HidAlgo, Isidro Gregorio y Díaz, Rosa María, "El yacimiento Arqueológico de 'Jamila' (Vva. de los Infantes)". En Luis Benítez de Lugo (coord.): El Patrimonio Arqueológico de Ciudad Real, Valdepeñas, 2000, pp. 323-353. 
Espadas, Juan José, Poyato, María Carmen y Caballero, Alfonso, "El poblado calcolítico ‘El Castellón' (Villanueva de los Infantes, Ciudad Real). Informe de la $2^{\mathrm{a}}$ campaña de excavaciones", Oretum, II (1986), pp. 235-247.

Espadas, Juan José, Poyato, María Carmen y Caballero, Alfonso, "Memoria preliminar de las excavaciones del yacimiento calcolítico de 'El Castellón' (Villanueva de los Infantes, Ciudad Real)", Oretum, III (1987), pp. 41-78.

Estévez GonzÁLEz, María Carmen, Marcadores de estrés y actividad en la población guanche de Tenerife. La Laguna: Universidad de La Laguna, 2002.

Estepa Diez, Carlos y Carmona Ruiz, María Antonia (eds..), La Península Ibérica en tiempos de Las Navas de Tolosa, Madrid: SEEM, 2014.

Ferembach, Denise, Schwidetzky, Ilse y Stloukal, Michal, «Recommendations pour déterminer l'âge le sexe sur le squelette», Bulletin et Memoir Sociales et Anthropologique. Paris 6, (XIII) (1979), pp. 7-45.

Fernández OchoA, Carmen y Morillo Cerdán, Ángel, "Entre el prestigio y la defensa: la problemática estratégico-defensiva de las murallas tardorromanas en Hispania", en Arqueología militar romana en Hispania, Jaraíz de la Vera, 2002, pp. 577-590.

Ferreira Fernandes, Isabel Cristina (ed.), Mil Anos de Fortificaçoes Na Península Ibérica E No Magreb (500-1500), Actas Do Simposio Internacional Sobre Castelos, Lisboa: Eds. Colibri, 2002.

Ferreira Fernandes, Isabel Cristina (ed.), Castelos das ordens militares, 2 vols. Lisboa: GEsOS-Município de Palmela, 2014.

Gallego Valle, David y Lillo-Fernández, Eduardo, "Estudio arqueológico del Castillo de la Estrella (Montiel) a través de sus técnicas constructivas", en Amador Ruibal (coord.): Actas del IV Congreso de Castellología, Madrid, 2012, pp. 439456.

Galtés Vicente, Joan Ignaci, Malgosa y Morera, Assumpció, “Atlas metodológico para el estudio de marcadores músculo esqueléticos de actividad en el radio", $P a$ leopatología, 3, (2007): www.erevistas.csic.es (acceso 15-VII-2014).

Galtés, Joan Ignaci, Jordana, Xavier; García, C y Malgosa, Assumpció, "Marcadores de actividad en restos óseos", Cuadernos de Medicina Forense, (13) (2007), pp. 179-189.

García Bueno, Carmen, "Aproximación al conocimiento del yacimiento arqueológico de Jamila (Villanueva de los Infantes, Ciudad Real): hallazgo monetario", Numisma, 247 (2003), pp. 55-73.

García de Cortázar, José Ángel, Portela, Ermelindo, Cabrera, Emilio, González, Manuel y LóPez DE CoCA, José Enrique, Organización social del espacio en la España medieval. La Corona de Castilla en los siglos VIII a XV. Barcelona: Ariel, 1985.

García de Cortázar, José Ángel, "La organización social del espacio en La Mancha medieval: propuesta metodológica y sugerencias de aplicación", en Espacios y 
fueros en Castilla-La Mancha (siglos XI-XV). Una perspectiva metodológica, J. Alvarado Planas (Coord.), Madrid, 1995, pp. 17-43.

GARCíA Fitz, F., "Una frontera caliente: la guerra en las fronteras castellanomusulmanas (siglos XI-XIII)", en Identidad y representación de la frontera en la España Medieval (siglos XIII-XV), C. de Ayala, P. Buresi y Ph. Josserand (eds.), Madrid, 2001 pp. 159-180.

Garrido Pena, Rafael, "El campaniforme en la Meseta Sur: nuevos datos y propuestas teóricas", Complutum, 6 (1995), pp. 123-151.

GonzÁlez González, J., El reino de Castilla en la Época de Alfonso VIII, Madrid: CSIC, 1960.

GonzÁlez GonzÁlez, J., Repoblación en Castilla La Nueva, 2 vols, Madrid: Universidad Complutense. 1975.

GonzÁlez GonzÁlez, J., "La Repoblación de la Mancha", en VII Centenario del Infante Don Fernando de la Cerda, Madrid, 1976, pp. 1-27.

González González, J., Reinado y diplomas de Fernando III. 3 vol. Córdoba: Monte de Piedad y Caja de Ahorros de Córdoba, 1986.

González Martín, Armando, Rascón, Josefina, Campo, Manuel, Cambra-Moo, Óscar, La evolución de "los niños": algunas reflexiones sobre el registro fósil infantil en Paleoantropología. Cadernos do GEEvH, 1(1), 2012. pp. 17-31.

Gruspier, K. L y Mullen, G. J., "Maxillary suture obliteration: A test of the Mann method", Journal of Forensic Sciences, 36 (1991), pp. 512-519.

Gutiérrez GonzÁlez, José Avelino, "La fortificación prefeudal en el norte peninsular...", en Mil Anos de Fortificaçoes Na Península Ibérica E No Magreb (5001500), Actas Do Simposio Internacional Sobre Castelos, I.C. Ferreira Fernandes (ed.), Lisboa, 2002, pp. 19-28.

Herrmann, B, Grupe, G., Hummel, S., Piepenbrink, H., y Schutkowski, Holger, Prähistorische Anthropologie. Leiffaden der Feld-und Labormethoden, Berlin, Heidelberg, New York: Springer Verlag, 1990.

Jiménez Brobeil, Silvia Alejandra, Al Oumaoui, Ihab y Esquivel, Juan Antonio, “Actividad física según sexo en la cultura argárica. Una aproximación desde los restos humanos", Trabajos de Prehistoria, 61 (2) (2004), pp. 141 - 153.

Juan, Antonio de, Sáinz, María José y SÁnchez-Palencia, Francisco Javier, "Excavaciones de urgencia en el cementerio islámico del Circo Romano de Toledo", en I Congreso de Historia de Castilla La Mancha. Tomo V, Toledo, 1988, pp. 41-49.

KenNEDy, Karl, "Skeletal Markers of Occupational Stress", en Reconstruction of life from the Skeleton, New York, 1989.

Krenzer, Udo, Traumas y paleopatología. Compendio de métodos antropológico forenses para la reconstrucción del perfil osteobiográfico, Tomo VIII. CAFCA, Guatemala: Centro de Análisis forense y ciencias aplicadas, 2006.

LAFFranchi, Zita, "Patrones de actividad en la Motilla del Azuer: un estudio a partir de restos óseos", @rqueología y Territorio. 7 (2010),pp. 57-68. 
Lapuente Martín, Marta, Características Biológicas de la Población de La Encantada (Granátula de Calatrava, Ciudad Real, II milenio a. C.), 2008.

Lomax, Derek W. "El arzobispo don Rodrigo Jiménez de Rada y la orden de Santiago", Hispania, LXXVI (1959), pp. 323-365.

López-BueIs, Inmaculada, "Marcadores de estrés musculoesquelético en los huesos largos de una población española (Wamba, Valladolid)", Sociedad Ibérica de Biomecánica y Biomateriales, 7 (13) (1999), pp. 94-102.

Madrid Medina, Ángela, “Jorge Manrique, comendador de Montizón”, Cuadernos de Estudios Manchegos, 18 (1988), pp. 327-340.

Madrid Medina, Ángela, "La Orden de Santiago hasta la conquista de Alcaraz", en A. Pretel (ed.), Alcaraz: del Islam al concejo castellano. Albacete, 2013, pp. 222242.

Madrid Medina, Ángela, "Los orígenes de la presencia de la Orden de Santiago en el Campo de Montiel", en P.R. Moya-Maleno (ed.): Campo de Montiel 1213: Entre el Islam y el Cristianismo. RECM Extra 1. Villanueva de los Infantes, en prensa.

Márquez Bueno, Samuel y Gurriaran Daza, Pedro, "Recursos formales y constructivos de la arquitectura militar almohade en al-Andalus", Arqueología de la Arquitectura, 5 (2008), pp. 115-134.

Martín Viso, Iñaki, Poblamiento y estructuras sociales en el norte de la Península Ibérica (siglos VI-XIII), Salamanca: Universidad de Salamanca, 2000.

Martín-Flórez, Juan Sebastián, "Caracterización antropológica de dos poblados de la Edad del Bronce de la Península Ibérica: el Castellón Alto y la Motilla del Azuer", @rqueología y Territorio, 7 (2010),pp. 69-80.

Martín Rodríguez, José Luis, Orígenes de la orden militar de Santiago (1170-1195). Barcelona: CSIC, 1974.

Martín Viso, Iñaki, Poblamiento y estructuras sociales en el norte de la Península Ibérica (siglos VI-XIII), Salamanca: Universidad de Salamanca, 2000.

Martínez Calvo, Victoria, "Excavación en la necrópolis medieval de la calle Lechuga s/n, Talavera de la Reina (Toledo)", en Actas de las II Jornadas de Arqueología de Castilla-La Mancha (Toledo, 2007), CD §4.07, Toledo, 2007, pp. 1-26.

Matellanes Merchan, José Vicente: "La colonización Santiaguista del Campo de Montiel", en Alarcos, 1195: Actas del Congreso Internacional Conmemorativo del VII Centenario de la Batalla de Alarcos, R. Izquierdo y F. Ruiz (coord.), Ciudad Real, 1996, pp. 389-414.

Matellanes Merchan, José Vicente, "La Orden de Santiago y la organización social de la Transierra castellano-leonesa (ss. XII-XIV)", Madrid: Universidad Autónoma de Madrid, 1999.

Miles, A, E, W., "Dentition in the estimation of age", Journal Dental Research, 42 (1) (1963), pp. 255-263.

MoléNAT, Jean-Pierre: "Les diverses notions de 'Frontière' dans la region de CastillaLa Mancha au temps des Almoravides et des Almohades", en Ricardo Izquierdo y Francisco Ruiz (coord.): Alarcos, 1195: Actas del Congreso Internacional Con- 
memorativo del VII Centenario de la Batalla de Alarcos, Ciudad Real, 1996, pp. 105-124.

Molero García, Jesús, “Torres refugio' en La Mancha Medieval”, en Mil Anos de Fortificaçoes Na Península Ibérica E No Magreb (500-1500), Actas Do Simposio Internacional Sobre Castelos, I.C. Ferreira Fernandes (ed.), Lisboa, 2002, pp. 803812.

Molero García, Jesús y Gallego Valle, David, "El primer encastillamiento cristiano en el Campo de Montiel (1213-c.1250)", en A. Pretel Marín (coord.), Alcaraz: del Islam al concejo castellano, Albacete, 2013, pp. 111-142.

Molina Chamizo, Pilar, "Reconquista y repoblación en el Campo de Montiel. Los primeros espacios para el culto cristiano. Capillas, iglesias y parroquias (siglos XIII-XIV", en P.R. Moya-Maleno (ed.): Campo de Montiel 1213: Entre el Islam y el Cristianismo. RECM Extra 1. Villanueva de los Infantes, en prensa.

Molina Chamizo, Pilar, Iglesias parroquiales del Campo de Montiel (1243-1515), Ciudad Real: Diputación de Ciudad Real, 1994.

Molina Moreno, María, La infancia en el Bronce de La Mancha: nuevas aproximaciones a los individuos no-adultos del yacimiento del Cerro de La Encantada (Ciudad Real, II milenio), Trabajo de fin de máster inédito, 2014.

Monsalve Romera, Alfonso, Marcadores de actividad en la población del Cerro de La Encantada: el papel de la mujer en un poblado de la Edad del Bronce manchego. Madrid: UCM., Trabajo de fin de máster inédito, 2013.

Moya-Maleno, Pedro R. (dir), Jamila, en preparación.

Moya-Maleno, Pedro R., “¿Caminante, no hay camino...? Territorio y economía de la Edad del Bronce a través de los pasos tradicionales: el Campo de Montiel entre la Meseta Sur y la Alta Andalucía", en OrJIA (coords.): II Jornadas de Jóvenes en Investigación Arqueológica, Vol. II, Zaragoza, 2011, pp. 643-650.

Moya-Maleno, Pedro R., "El 'Entorno Jamila' (Villanueva de los Infantes, Ciudad Real): de la iniciativa personal a un proyecto de gestión integral de la investigación arqueológica”, en Jaime Almansa (ed.): Arqueología Pública en España, Madrid: JAS Arqueología, 2003, pp. 351-374.

Moya-Maleno, Pedro R., "García y Bellido y la Arqueología del Campo de Montiel (Ciudad Real-Albacete): aproximación historiográfica”, en Ídem (Ed.): Antonio García y Bellido. 1903-2003, Villanueva de los Infantes, 2006, pp. 63-138.

Moya-Maleno, Pedro R., "Procesos de reconquista, repoblación y abandono medievales en el Campo de Montiel: la aldea fortificada de Peñaflor", en Id. (ed.): Campo de Montiel 1213: Entre el Islam y el Cristianismo. RECM Extra 1. Villanueva de los Infantes, en prensa.

NiÑo, Francis Paola, "Metodología para el registro de marcadores de estrés musculoesquelético", Boletín de Antropología, 19 (36) (2005), pp. 255-268.

Parcero Oubiña, César, "Tres para dos. Las formas de poblamiento en la Edad del Hierro del Noroeste ibérico", Trabajos de Prehistoria, 57(1) (2000), pp. 75-95. 
Porras Arboledas, Pedro Antonio, "La repoblación de La Mancha santiaguista en tiempos de Alfonso XI", Cuadernos de Historia de Derecho, 2 (1995), pp. 59-98.

Poyato Holgado, María Carmen y Espadas Pavón, Juan José, "El Castellón, un importante yacimiento con campaniforme en Villanueva de los Infantes (Ciudad Real)", en I Congreso de Historia de Castilla- La Mancha, vol II, Ciudad Real, 1988, pp. 207-211.

Poyato Holgado, María Carmen y Galán y Saulnier, Catalina, "Las cerámicas del 'grupo Dornajos' de la Mancha Oriental", en I Congreso de Historia de CastillaLa Mancha, vol II, Ciudad Real, 1988, pp. 301-310.

Pretel Marín, Aurelio, "Conflictos de interés en el repartimiento y la repoblación de una villa realenga (Alcaraz) durante el siglo XIII", Historia. Instituciones. Documentos, 27 (2000), pp. 235-274.

Pretel Marín, Aurelio, Alcaraz y su tierra en el siglo XIII. Albacete: Instituto de Estudios Albacetenses, 2008.

Pretel Marín, Aurelio, “¿Pervivencias cristianas bajo dominio islámico en las sierras de Alcaraz y Segura?", en Mozárabes. Identidad y continuidad de su historia, Murcia, 2011, pp. 355-388.

Pretel Marín, Aurelio, Alcaraz: del Islam al concejo castellano. Albacete: Instituto de Estudios Albacetenses, 2013.

Proyecto Fin de Carrera. Biología Evolutiva y Biodiversidad. Madrid: Universidad Autónoma de Madrid.

Retuerce Velasco, Manuel, "Cerámica medieval, moderna y contemporánea de Villanueva de la Fuente (Ciudad Real)", en Luis Benítez de Lugo (coord.): Mentesa Oretana: 1998-2002, Valdepeñas, 2003, pp. 247-254.

RoBledo Sanz, Beatriz, Dieta, indicadores de salud y caracterización biomorfológica de la población medieval musulmana de Xarea (Vélez Rubio, Almería), Madrid: Universidad Complutense, 1998.

Rodríguez Molina, José, "Las Ordenes Militares de Calatrava y Santiago en el Alto Guadalquivir (Siglos XIII-XV)", Cuadernos de Estudios Medievales, II-III (19741975), pp. 59-83.

Rodríguez-Picavea Matilla, Enrique, "La ganadería en la economía de frontera. Una aproximación al caso de la meseta meridional castellana en los siglos XI-XIV", en Identidad y representación de la frontera en la España Medieval (siglos XIII-XV), C. de Ayala, P. Buresi y Ph. Josserand (eds.), Madrid, 2001 pp. 181-204.

Rodríguez Untoria, Santiago, "Excavación Arqueológica en Avenida General Villalba $\mathrm{N}^{\mathrm{o}} 20,22$ y 34 (Toledo) Aporte al Estudio de la Necrópolis Medieval de Toledo", en Actas de las II Jornadas de Arqueología de Castilla-La Mancha (Toledo, 2007), CD §4.11, Toledo, 2007, pp. 1-35.

Rojas Rodríguez-Malo, Juan Manuel y García Vacas, Luis, "La excavación en la calle San Juan (prolongación s/n), en Santa Olalla, Toledo. De Al-Ándalus hasta nuestra Era", en Actas de las II Jornadas de Arqueología de Castilla-La Mancha (Toledo, 2007), CD §4.12, Toledo, 2007, pp. 1-23. 
Ruibal Rodríguez, Amador "Un enclave de la Orden de Santiago en el Campo de Montiel: Alcubillas", Castillos de España, 91 (1986), pp. 35-40.

Ruibal Rodríguez, Amador, "El Castillo de Alhambra", Cuadernos de Estudios Manchegos, 16 (1985), pp. 153-166.

Ruibal RodríGuEz, Amador, "El enclave de Montiel: vestigios de los antiguos castillos de la Estrella y San Polo y el lugar de Torres", Anuario de Estudios Medievales, 14 (1984), pp. 143-185.

Ruibal Rodríguez, Amador, "Eznavexore o ¿Torres de Xoray?: vestigios islámicos en el primer enclave santiaguista de Ciudad Real", Al-Qantara, V. (1984), pp. 429449.

Ruibal Rodríguez, Amador, "Peñaflor y Saujuolo, dos despoblados cristianos del siglo XIII", en Arqueología Medieval Española. II Congreso, Tomo III, Madrid, 1987, pp. 672-678.

Ruiz Gómez, Francisco, Los orígenes de las órdenes militares y la repoblación de los territorios de La Mancha (1150-1250), Madrid: CSIC, 2003.

Ruiz TABOADA, Arturo, La vida futura es para los devotos. La muerte en el Toledo medieval,Madrid: La Ergástula, 2013.

SÁnchez-Albornoz, Claudio, Despoblación y repoblación del Valle del Duero, Buenos Aires: Instituto de Historia de España, 1966.

SÁnchez SÁnchez, Jesús, "Los caminos de la batalla: las Navas de Tolosa, 1212", en Actas del VI Congreso de Caminería Hispánica, Tomo II, Madrid, 2004, pp. 793820.

SÁnchez SÁnchez, Jesús, "Caminos históricos Toledo-Córdoba por el Valle de Alcudia”, en Actas del VII Congreso de Caminería Hispánica, Madrid, 2006, pp. 1-24.

SAncho, Marta, "Els Altimiris", en Pierre Senac (ed.): Villa 3. Histoire et Archéologie des Sociétés de la Vallée de l'Ėbre (VIIe - XIe siècles), Toulouse, 2010, pp. 67-90.

SANTAMaría Gutiérrez, Josu, Geometría de cortes transversales de una población arqueológica de Logroño: investigación biomecáncia: dimorfismo sexual y asimetría bilateral de miembros superiores. Proyecto fin de máster. Madrid: Universidad Autónoma. Madrid, 2008.

SANTANA CABRERA, Jonathan A., El trabajo fosilizado: patrón cotidiano de actividad física y organización social del trabajo en la Gran Canaria prehíspánica. Universidad de las Palmas de Gran Canaria. Departamento de Ciencias Históricas. Universidad de las Palmas de Gran Canaria, 2011.

SAntana CABrera, Jonathan, "Marcadores Óseos de actividad Física en la Población aborigen de Gáldar (siglos XI-XV d.n.e)", Vegueta. 11 (2010), pp. 101-122.

Schaefer, Maureen, Black, Sue y Scheuer, Louise, Juvenile osteology. San Diego: Elsevier, 2009.

Serrulla Rech, Fernando (coord.), Recomendaciones en antropología forense. Valdepeís: Asociacion Española de Antropología y Odontología Forense, 2013. 
Trancho Gallo, Gonzalo Javier, ROBLEDO, Beatriz, "Hipoplasia del esmalte dental: un indicador patológico", Gaceta dental, 107 (2000), pp. 56-64.

Trotter, Mildred y Gleser, Goldine, "Re-evaluation of estimation of stature based on measurements of stature taken during life and of long bones after death", American Journal of Physical Anthropology, 16 (1958), pp. 79-124.

Trotter, Mildred y Gleser, Goldine, "Trends in stature of American whites and negroes born between 1840 and 1924", American Journal of Physical Anthropology. 9 (4) (1951), pp. 427-439.

UbelaKer, Douglas H., Human Skeletal Remains: Excavation, analysis, interpretation, Washington: Tarazacamun, 1978.

Vigil-Escalera Guirado, Alfonso, "El modelo de poblamiento rural en La Meseta y algunas cuestiones de visibilidad arqueológica", en J. López Quiroga, A.M. Martínez Tejera y J. Morín (eds.), Gallia e Hispania en el contexto de la presencia 'germánica' (ss. V-VII), Londres, 2006, pp. 89-108.

Vigil-Escalera Guirado, Alfonso, "Sepulturas, huertos y radiocarbono (siglos VIIIXIII d.C.). El proceso de islamización en el medio rural del centro peninsular y otras cuestiones", Studia Historica, Historia Medieval, 27, 2009, pp. 97-118.

Vigil-Escalera Guirado, Alfonso, "Prácticas y ritos funerarios", en J.A. Quirós Castillo (ed.), El poblamiento rural de época visigoda en Hispania. Arqueología del campesinado en el interior peninsular, Bilbao. 2013, pp. 259-288.

Vigil-Escalera Guirado, Alfonso y Tejerizo Garcia, Carlos, "Asentamientos Fortificados Altomedievales en la Meseta: Algunas distorsiones historiográficas", en R. Catalán, P. Fuentes y J.C. Sastre (eds.), Las fortificaciones en la tardoantigüedad: Élites y articulación del territorio (siglos V-VIII d.C.), Madrid, 2014, pp. 229-246.

Villote, Sebastien, Castex, Dominque, Couallier, Vincent y Dotour, Oliver, "Enthesopathies as Occupational Stress Markers: Evidence from the Upper Limb", American Journal of Physical Anthropology. 141 (2010), pp. 222-223.

Wilczac, Cynthia A. y Kennedy, Karl A. R., "Mostly MOS: Aspects of Identification of Skeletal Markers", en J.K. Reichs (eds.), Forensic Osteology, Springfield, 1998, pp. 461-490. 